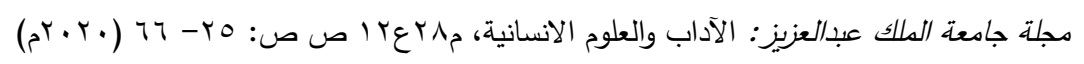

DOI:10.4197/Art.28-12.2

\title{
جهود أهالي جدة في توفير المياه العذبة لمدينتهم
}

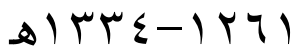

p) $917-11 \leq 0$

\author{
د. دلال بنت محمد سليمان السعيد \\ قسم التاريخ والآثار كلية العلوم الاجتماعيت \\ جامعة جلة
}

مستخلص. تتضمن هذه الدراسة موضوعاً عن جهود أهالي جدة لتوفير المياه العذبة لمدينتهم، خلال الفترة الممتدة

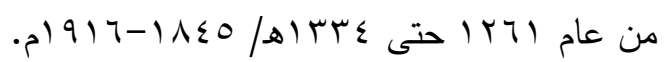
وتكمن أهمية الموضوع في أنه دراسة حضارية تلقي الضوء على مورد حيوي ورئيسي لاستمرار الحياة هو الماء، كما أنها دراسة جديدة لم يسبق أن تم التطرق إليها بتوضيح جهود أهالي جدة ورصد أعمالهم المباركة لتوفير المياه

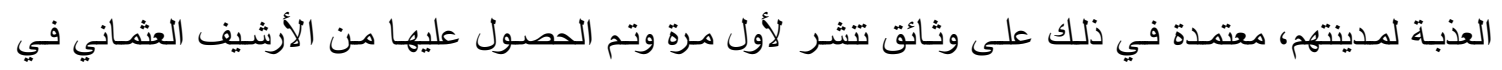

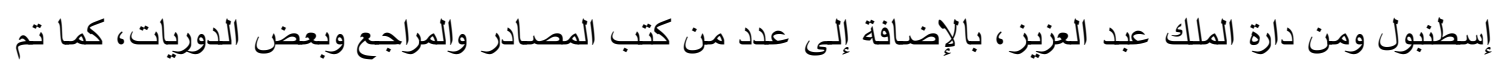

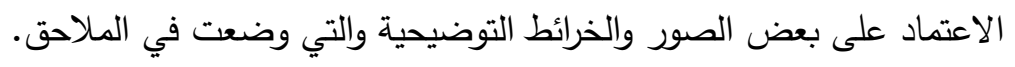

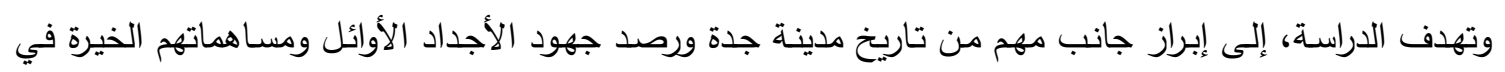
خدمة مدينته، وفي التكاتف فيما بينهم بالبذل والعطاء ودعم الدولة الحاكمة والوقوف معها ومساندتها، كما تهدف إلى الاطلاع على معاناة الأهالي في الماضي وما تحملوه من صعاب من أجل توفير قطرات من المياه العذبة مما يتطلب منا بذل الجهد في الوقت الحاضر للحفاظ على ما نحن فيه من خير وفير بالحرص على ترشيد استهلاك فئك المياه وعدم الاسراف في استخدامه، ومن أهداف الدراسة أيضاً، تشجيع الباحثين والمؤرخين والآثاريين على القيام بدراسات توضح جوانب مجهولة أو غامضة من تاريخ مدينة جدة وكثف النقاب عنها.

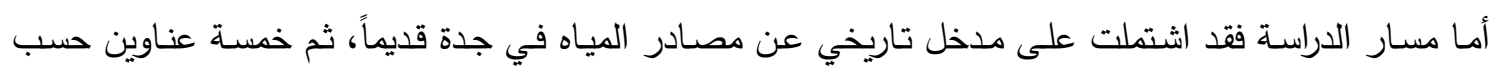
الفترات التاريخية والمشاريع التي تم تتفيذها، وهي تتضمن مبادرة التاجر فرج يسر في إعادة مد قنوات الماء العذب فئب 
من الرغامـة شرق جدة، ثم ترميم العين، وبعدها محاولات التاجر سليم سلطان لتحلية مياه البحر ، ثم إجراء عين الحميدية "الوزيرية" ودعم أهالي جدة في انشائها، كما تم التطرق إلى جهاز تحلية مياه البحر "الكنداستة"، وأخيراً عن إنداء قيام الأهالي بتثكيل شركة وطنية للتتقيب عن مصادر المياه في مدينة جدة، وقد اختتمت الدراسة بعدد من النتائج الهامة التي تم التوصل إليها.

الحاجة إليها، كما أنها دراسـة جديدة لـ يسبق أن تم التطرق إليها في الكتب والمؤلفات بتوضـيح جهود أهـالي جدة ورصـد أعمـالهم المباركـة لتوفير الميـاه العذبة لمدينتهم معتمدةً في ذلك على وثائق تنشر لأول مرة. - أول أما أهداف هذه الاراسة فتتمثل في الآتي: - القاء الضوء على جانب من تاريخ مدينـة جدة، من خلال التركيز على موضوع حيوي ومهم يعتبر من المتطلبات الضرورية لأي مجتمع. منيك

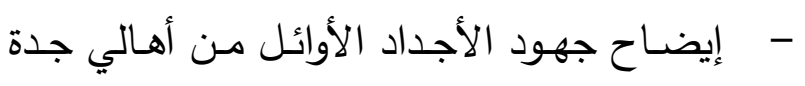
وإبراز مساهماتهم الخيرة في خدمة مدينتهم وتكاتفهم فيما بينهم بالبذل والعطاء ودعم الدولة والوقوف معها ومسـاندتها في مشـاريع توفير الميـاه لتحقيق الرخـاء لجميع السكان. - - الإطلاع على معاناة الأهالي في الماضي وما تحملوه من صعاب من أجل توفير قطرات من المياه

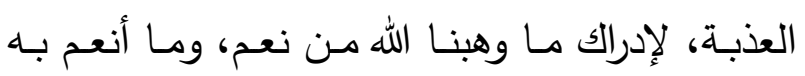
علينـا مـن خيـر وفيـر في الوقـت الحاضـر والـذي يتطلب منـا بـذل الجهد للحفـاظ على هذه النعمـة، بالحرص على ترشيد استهلاك المساء وعدم الإسراف

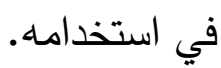

\section{المقدمة}

الحمد لله رب العالمين والصـلاة والسـلام على أشرف المرسلين سيدنا محمد وعلى أله وصحبه أجمعين. تعرض هذه الدراسة لموضوع بعنوان " جهود أهالي

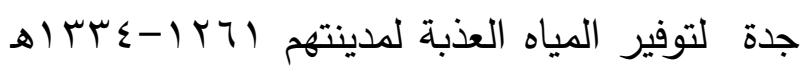
. $917-1 \wedge \leq 0 /$ وهي فترة عانـت خلالها هذه المدينـة - وكمـا كان حالها سابقاً - من نقص المياه العذبة وعدم توفره في معظم الأحيان، وقد بُدئت الدراسـة بهذا التاريخ لأنـه يمثل أول محاولـة قـام بها أحد أهـالي جدة لتوفير

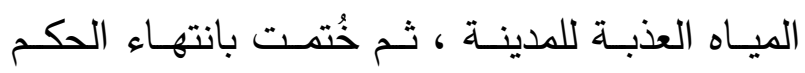
العثماني على الحجاز عام ع سباهـ/ اهـ (9 (م. وتكمن أهمية الموضوع في أنه دراسـة حضسارية تُلقي الضوء على مورد حيوي ورئيسي لاستمرار الحياة هو الماء، قال تعالى: ((وجعلنا من الماء كل شيء حي أفـلا يؤمنـون)) (سـورة الأنبيـاء : (آيـة · ب)، ولمدينـة مهمـة كانـت ولا تزال بوابـة الحرمين الثـريفين، مكـة

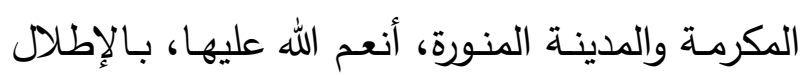
على سـاحل بحـري منحهـا فرصـة اسـتخلال مـاءه، حيث تمت على أرضها تطبيق التقنية الحديثة لأول مـرة خـلال تلك الفترة بتحليـة ميـاه البحر للحصـول

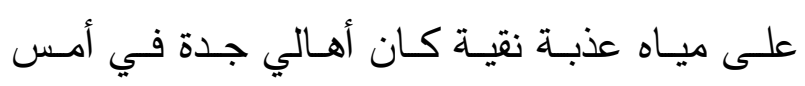


وبعد ذلك آلة تحلية المياه "الكنداسة" ونصبها لأول مرة في مدينـة جدة، وأخيراً عن قيام الأهالي بإنثـاء ولهاء

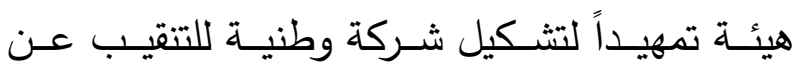
مصـادر للميـاه تكون قريبـة مـن مدينتهم ثم جـاءت فئه

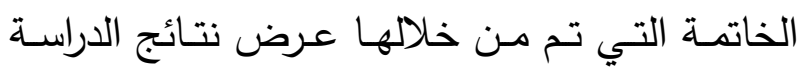
والتـي تضــنت بعـض الآراء والحقـائق التاريخيـة، والتي لا يزال باب النقاش مفتوحاً لبعضها متى ما تم

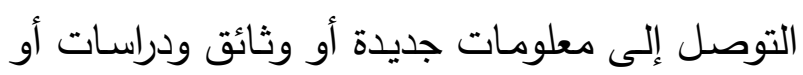
العثور على آثار كامنة لتؤكد هذه النتائج أو تنفيها،

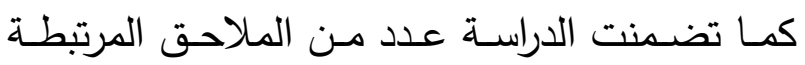
بالموضوع وأخيراً قائمة المصادر والمراجع.

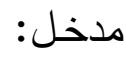
عُرفت مدينة جدة بندرة وجود المياه العذبة الصالحة للشرب فيها، وذلك لوقوعها على ساحل بحر شديد

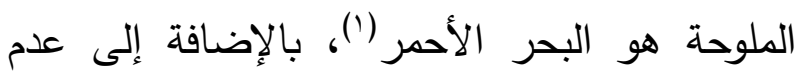

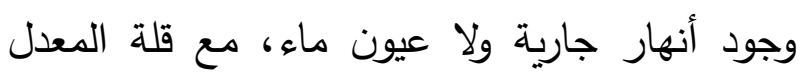
السنوي لتساقط الأمطار، وفي حال تم الحفر للبحث عن مياه عذبة فأغلب ما يخرج من باطن الأرض

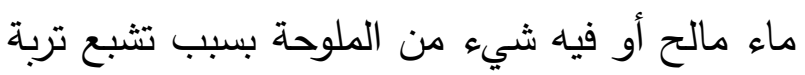

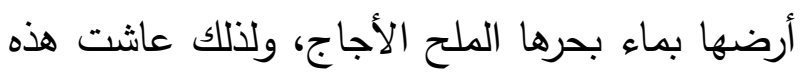
المدينة هماً دائماً طوال عصورها التاريخية نظراً

(1) عُرف عن البحر الأحمر أن مياهه تزيد نسبه الملوحة فيه عن البحار

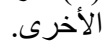

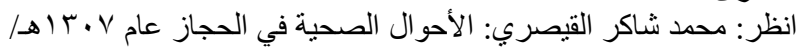

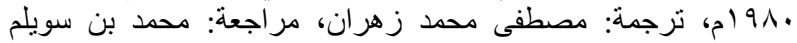

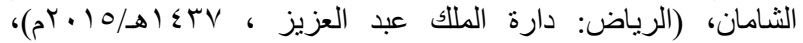

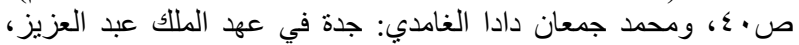

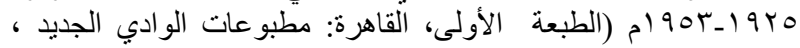

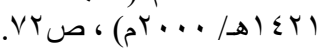

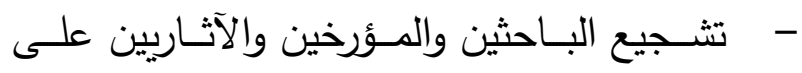
القيام بعمل الدراسات التي توضح جوانب غامضة أو أو مجهولة من تاريخ مدينـة جدة، والتنقيب عن الآثار

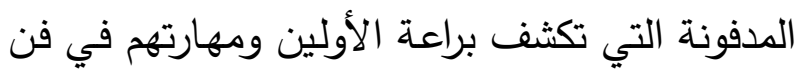
البنـاء والعمـارة رغم نقص الإمكانيـات المتاحـة لهم

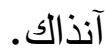
أما مصادر الدراسة لهذا الموضوع فقد اشتملت على مصـادر ومراجـع متتوعـة، حيـث اعتمـدت المـادة

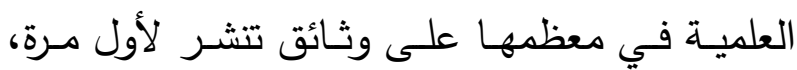

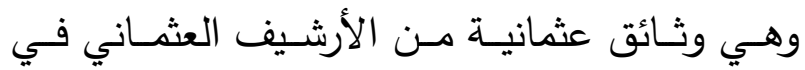
اسطنبول، ومن الوثائق العثمانية المحفوظة في دارة

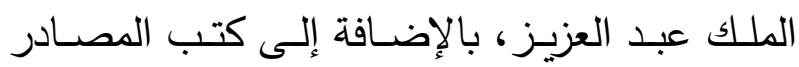

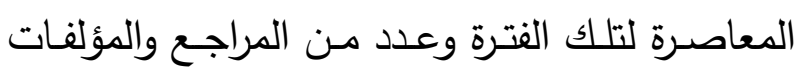
والدوريات المرتبطة بهذا الموضوع.

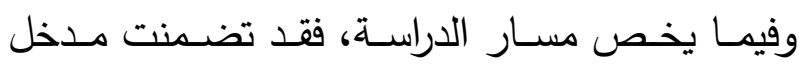
تاريخي عن مصادر المياه في مدينة جدة قديماً، ثم موضوع الدراسة عن جهود الأهالي ومحاولات الدولة العثمانيـة في توفير المياه العذبة لمدينة جدة، حيث الهن تم تقسيم الموضوع إلى عدة عناوين اشتملت على

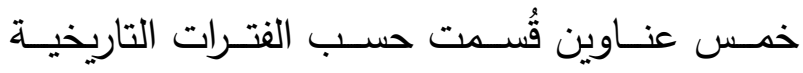
والمشاريع التي تم تتفيذها من قبل الأهالي، وكانت

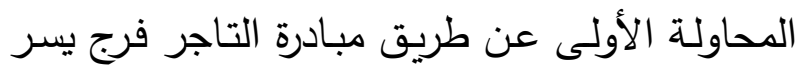
عوض عباد، وبعدها الحديث عن ترميم قناة العين

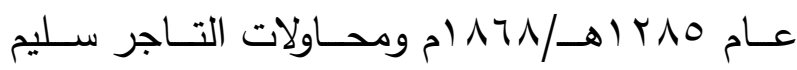
سـلطان لتحليـة ميـاه البحـر، ثم عـن إجـراء العـين

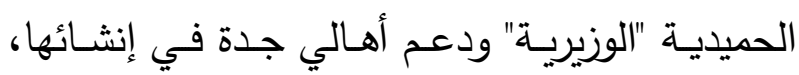


الرخام أو الحجر الصـلد وتكون مستديرة الشكل عـادةً.

وقـد قـام القـادرون مـن أهـالي جـدة بينـاء صـهاريج ضخمة داخل المدينـة وخارجها، وحفروا حفراً كثيرة وكبيـرة فـي أمـاكن متعـددة حيــث يملؤونهـا بميـاه الأمطار التي تتجمع في هذه الصهاريج(•)، ويجعلون فيها مداخل للمـاء ومصـارف تخرجـه حسـب الحاجـة إليه(")، أما موقعها خارج البلدة فقد كانت تُنى على طريـق الأوديـة التـي تتـدفق فيهـا ميـاه السـيول بعـد هطول الأمطار ، وكانت تمثل للبعض تجارة مربحة آنذاك(V). ومياه الصهاريج في الغالب ليست صمحية ولـا فقد كـان الأغنيـاء يجلبـون مـاءهم مسن الآبـار

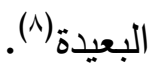

وقد ظل أهـالي جدة يعتمدون على هذه المصـادر

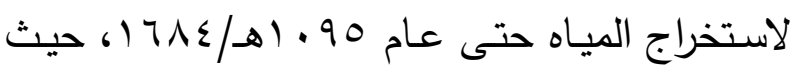
بـدأت الدولـة العثمانيـة في محاولـة جلب الميـاه مـن

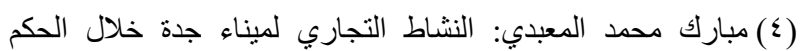

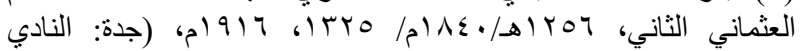

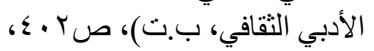

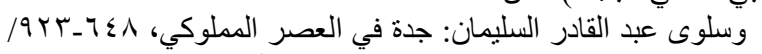

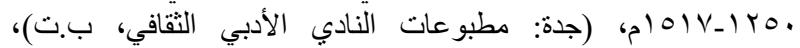

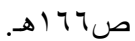
(0) أيوب صبري باشا: مر آة جزيرة العرب، ترجمة و تقديم وتعليق: أحمد

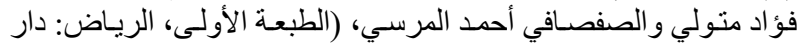

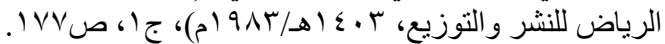

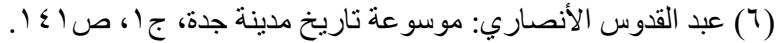

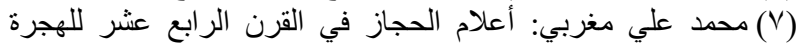

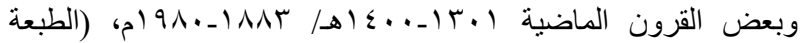

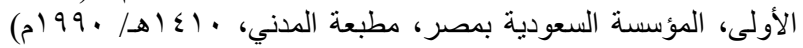

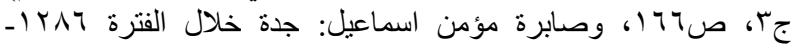

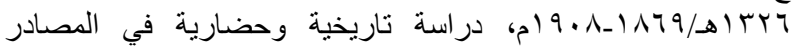

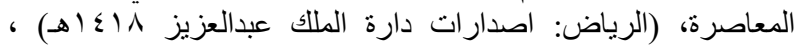

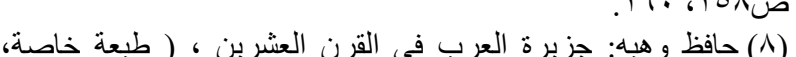

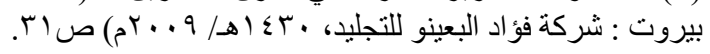

لحاجتها المتزايدة للمياه العذبة لتفي بمتطلبات ساكنيها والوافدين إليها(')، حيث كانوا يحصلون على المياه العذبة من مصدرين هما:

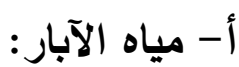
فقد حرص أهالي جدة على حفر الآبار لاستخراج المياه العذبة، وقد اجتهدوا في الحفر خارج البلدة أو الوال بعيداً عنها، وكلما بعدت الآبار عذب ماؤها وطاب، وكلما كانت داخل المدينة غلبت عليها الملوحة النسبية(ץ)، بالإضافة إلى ذلك، قام الأهالي بحفر الآبار في منازلهم لتأمين احتياجاتهم من المياه، كما كانت أغلب المساجد تحوي بئراً في إحدى جنبات المسجد حيث يستفاد من مياهه إما للشرب أو لنظافة المسجد أو لتأمين مياه الوضوء للمصلين وهذا هو

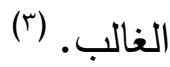

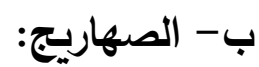
والصـهريج هو حوض يتم فيـه تجميع مياه الأمطار الموسمية وينى في الغالب من الآجر أو الأحجار

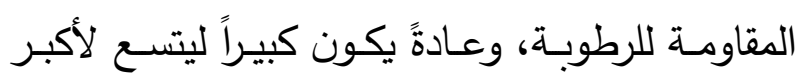
قدر مدكن مـن المياه التي يمكن تخزينها، وكانت

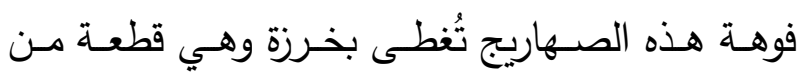

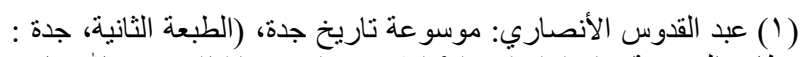

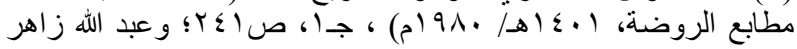

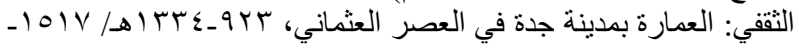

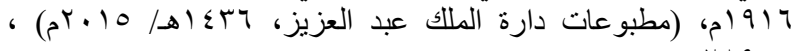

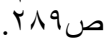

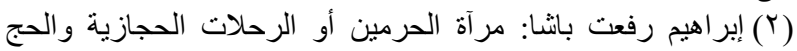

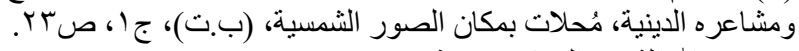

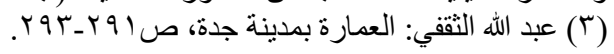


إلى جدة، وقد وصل المهندس ومن معه إلى جدة يوم الجمعة 7 الجى شهر صفر، الموافق ل ب يونية وظلوا فيها حوالي احدى عشر يوماً حيث تم الإشراف على العين الموجودة فيها، وتقدير تكلفة عمارتها التي ذُكر بأنها قد تصل إلى أربعين ألف شريفي أحمر (॰). وتقدير المبلغ المالي الذي يكلفه إجراء العين ومسير المهندس مع البنائين يوحي بأن توجههم لمعاينة الموقع كان بهدف دراسته وتقدير تكلفة القيام بهذا المشروع ولم يكن يهدف إلى البدء في القيام بتنفيذ المشروع وعمل التمديدات اللازمة له. وفي عام 90 •اهـ/1/7ام، وصل المعمار كرد أحمد إلى الحجاز للقيام بأعمال معمارية في البيت الحرام، ثم اتجه إلى مدينة جدة التي عمل بها على مشروع إجراء العين ابتدأها من المحل المعروف بالقوز في الرغامة وعمر بها مسجداً ومنارة ووكالة وحماماً واستغرق العمل به مدة ثلاث سنوات(؟)، وقد توفر لمدينة جدة آنذاك مياه عذبة نعم بها الأهالي والوافدين فترة من الزمن قاربت الأربعون عاماً، وبعدها توقف جريان الماء واقتضت الحاجة إلى إصلاح العين، حيث عمل علي باشا(V) والي جدة في ولي

(0) علي بن تاج الدين السنجاري: منائح الكرم في أخبار مكة والبيت

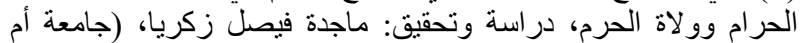

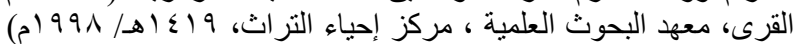

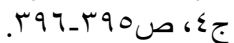

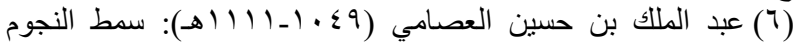
العوالي في أنباء الأوائل و التوالي، (القاهرة: المطبعة السلفية ومكتتبها،

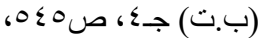
وعادل غباثي: "إيصال مياه العيون إلى مدينة جدة"، مرجع سابق،

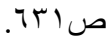
(V) علي باثـا أمير الحج ووالي الثام والذي تولى في الوقت نفسه ولاية

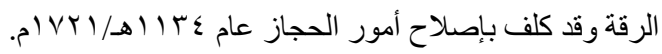

عين وادي قوز الواقعـة شمال الرغامـة شـرق مدينـة

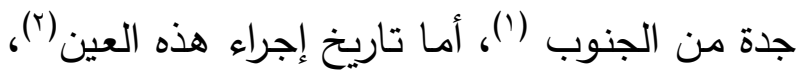

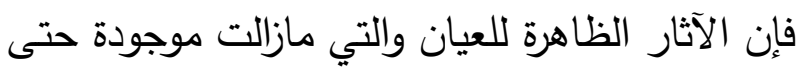

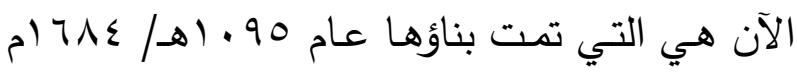

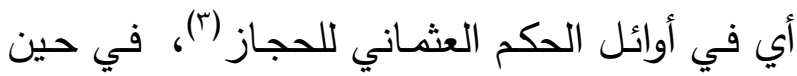

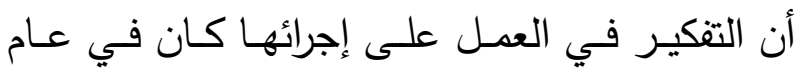

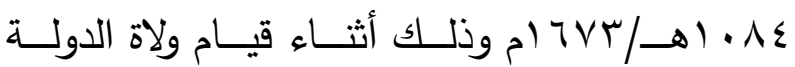

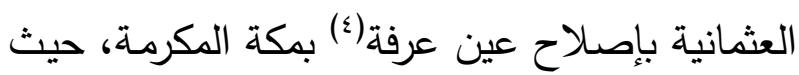

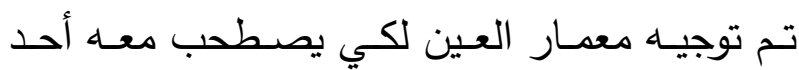
المهندسين القادمين من مصر للتوجه إلى مدينة جدة وبرفقتهم بعض المعلمين البنائين بهدف معاينة عين ماء هناك بلغ السلطنة أنها إن عُمرت دخلت المياه

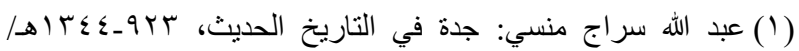
(9T4_ 101V - ولجنة العلاقات العامة بإدارة العين العزيزية : لـحاتهات عن العين

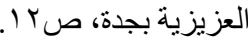

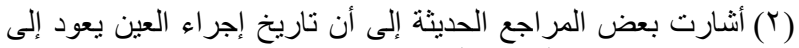

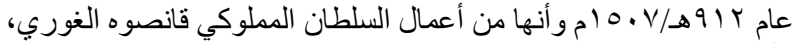

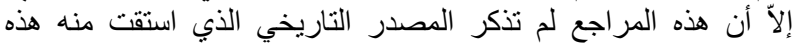

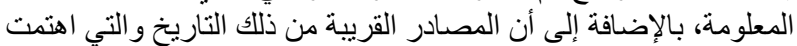

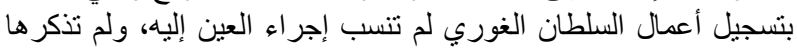
ضمن أعماله التي أوردها أبلالتفصيل. التوريل

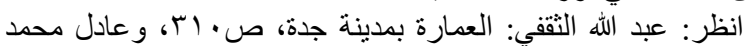

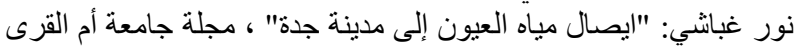

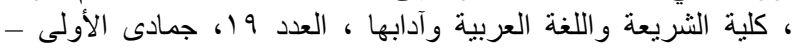

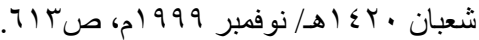

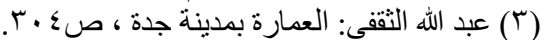

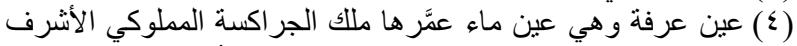

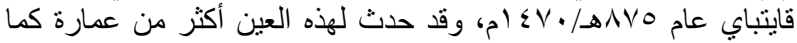

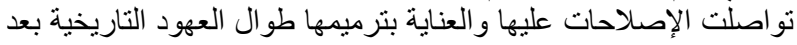
ذلظك. : نقاهد طاهر الكردي: التاريخ القويم لمكة وبيت الله الكريم، طبعة

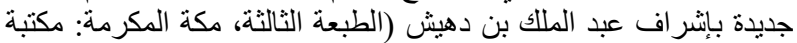

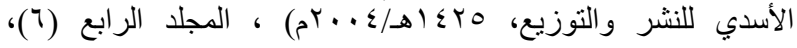

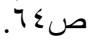

ومحمد علي فهيم: ملامح النشاط الاجتماعي في مكة المكرمة في القرن

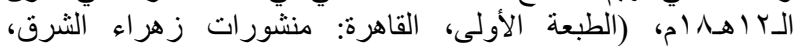

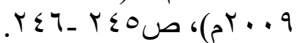


والأيتام، وكـان يملك اسطولاً مـن البواخر الثـراعية

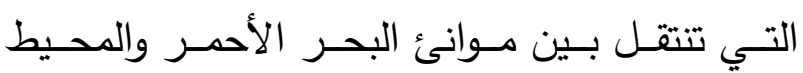
الهندي(0)، وقد تحدثت الوثائق العثمانيـة عن ثرائهـ

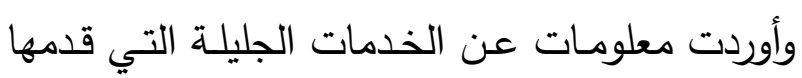

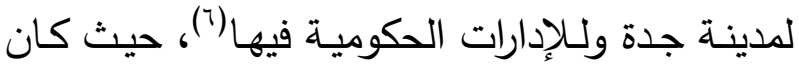

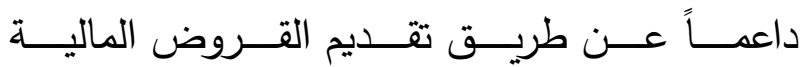
لهم (У)، ولزوجات السلاطين أثناء زيارتهم للحجاز (^)،

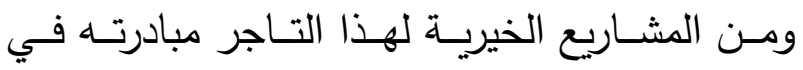
الثروع بإعـادة مد قنوات المـاء العذب من الرغامـة

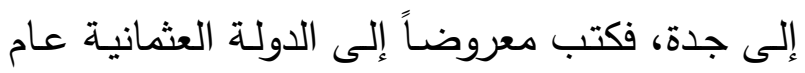

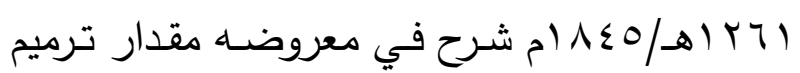
قنوات العين، ثم بدأ بالعمل على محاولات مد الماء

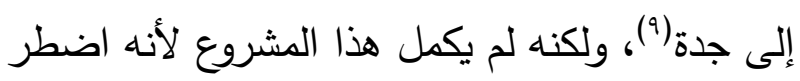

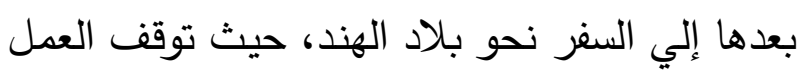

في نفس المنطقة بحي البلد في جدة التاريخية برحة باسمه والمعروفة

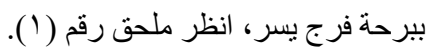

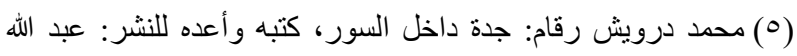

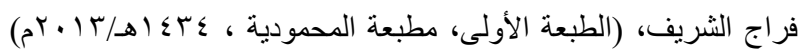

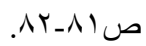
(7) سهيل صابان: مداخل لبعض أعلام الجزيرة العربية في الأرشيف

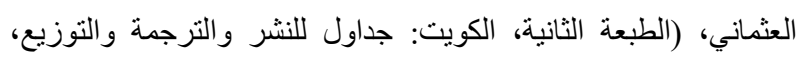

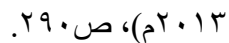
الأرشيف العثماني بإسطنبول ، (V)

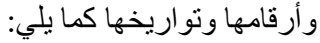
باريخ A.MKT.MVL -

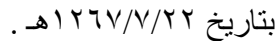
A.AMD - -

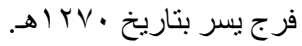

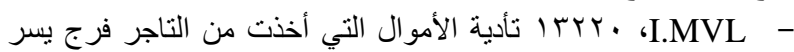

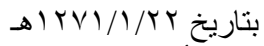
(^) ب.MKT.NZD

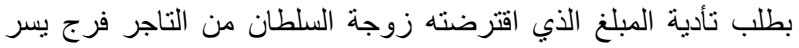

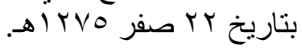
(9) عبد الله الثقفي: العمارة بمدينة جدة، صـ ــ بـ
عام هبr||(هـ/VYr ام على إعادة جريان الماء، كما أرسل إلى أحد التجار هو الثيخ سالم البصري يطلبه

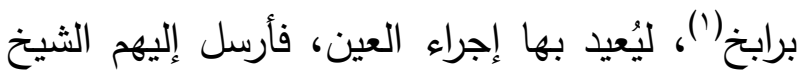

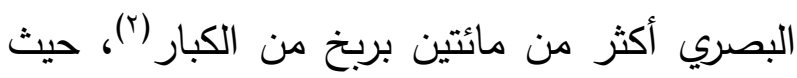

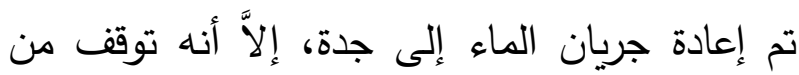
جديد، وعاد الأهالي إلى الاعتماد على مياه الآبار

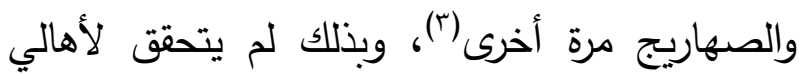

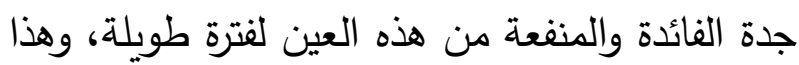
يعني استمرار نقص المياه العذبة في المدينة وتزايد الحاجة لها.

جهود أهالي جدة في توفير المياه العذبة لمدينتهر:

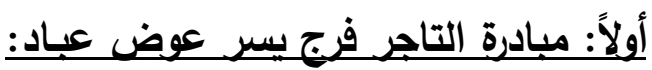
فرج يسر أحد تجار جدة ووجهائها في العهد العثماني الثـاني، عُـرف عنــه حبــه لأعمــال الخيـر والبــر

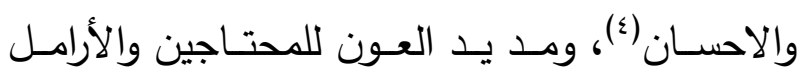

انظر: اسماعيل حقي جارستلي: أمر اء مكة في العهد العثاني ، ترجمة :

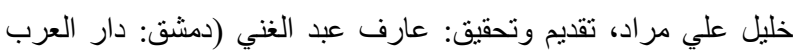

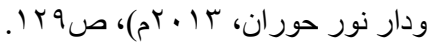

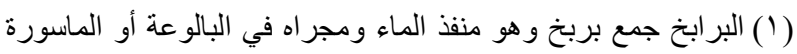
وتكون من الخزف أو الفخار و غيره. انظر : عبد الله بن محمد الغازي: أفادة الأنام بذكر أخبار بلد الله الحرام

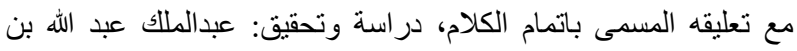

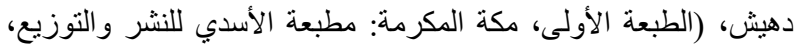

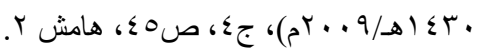

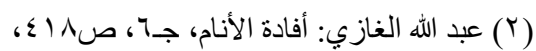

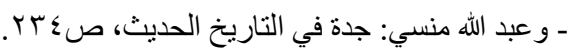

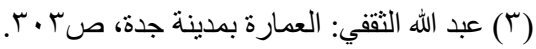
( ) ومن آثاره الخيرية الباقية في مدينة جدة مسجد يحمل اسمه حتى الآن،

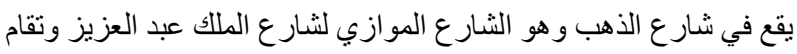
في هذا المسجد الصلوات الخمس حتى يومنا هذا.

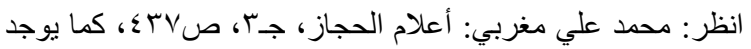


ابتغاء وجه الله، ولمنفعة عموم سكان وأهالي جدة(؟)، وقـد قـام والـي جـدة بتحويـل رسـالة فرج يسـر إلـى المجلس العـالي، حيث قرر المجلس منـح الرخصـة لهه، لإصـالاح مـا تهدم من مجاري العين حيث كان رأي أعضــاء المجلـس أن التــاجر المــذكور مــن أصـحاب المكانـة لـى السـلطنة، وفـاق أمثالـه ممـن يرغبون في القيام بمثل تلك الأعمـال الخيريـة، كمـا رأى المجلس أن يقوم الوالي اللاحق بترغيب وتشجيع التاجر المذكور على القيام بإتمام الترميمات(؛)، وتم التصديق على طلب فرج يسر وموافقة السلطان على

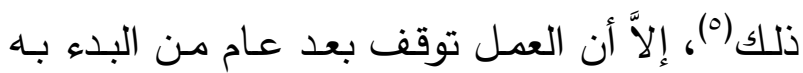
بسبب ما قام به الثريف محمد بن عون(؟) بجمع كل

I.MVL الأرشيف العثماني بإسطنبول ، قسم الوثائق، اسم التصنيف)

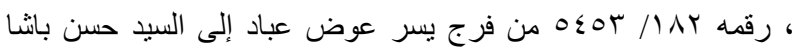

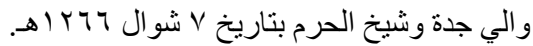
انظر نص المعروض باللغة العربية في ملحق رقمُ (r).

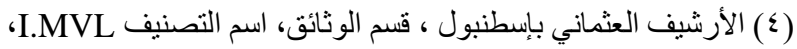

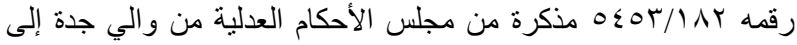

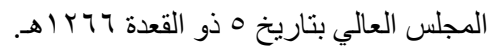
I.MVL الأرشيف العثماني بإسطنبول ، قسم الوثائق، اسم التصنيف (0)

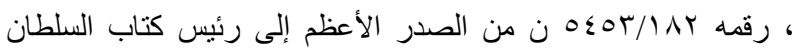

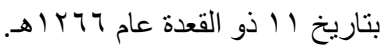

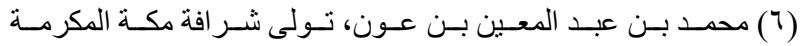

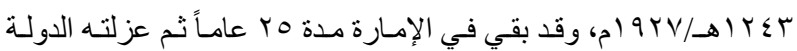

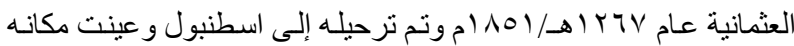

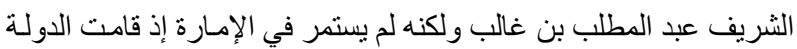

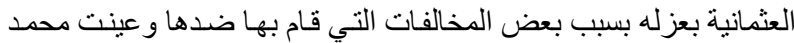

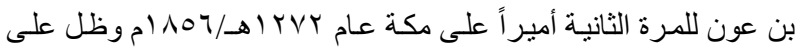

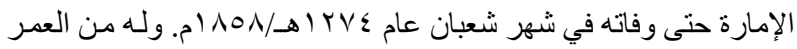

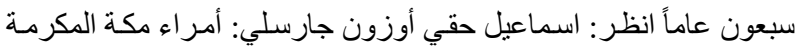

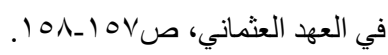

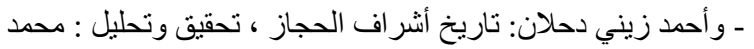

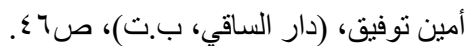

بالمشروع عدة سنوات، وخلال فترة التوقف تلك كان

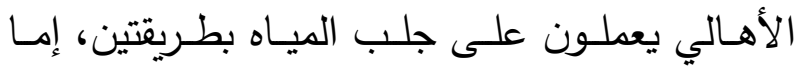
بواسـطة الإبـلـل بجلب المـاء مـن المكـان المســى

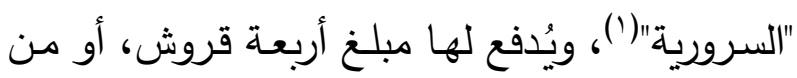

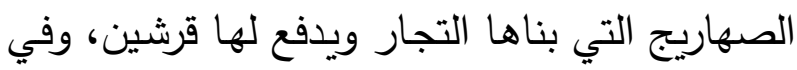

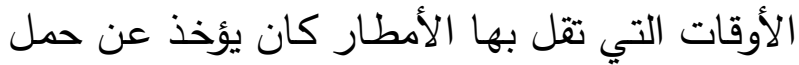
الإبل الواحد من المياه مبلغ اثنـا عشر قرشـاً وكان

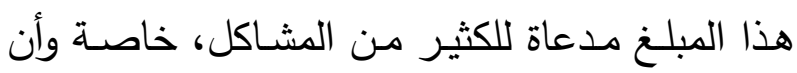
المياه كانت غير مستساغة للثرب إلى حد كبير، لذلك أصبح ضـرورياً ترميم واصـلاح مجرى العـين الذي كانت تكلفتها من سبع إلى ثمان مائة كيساً من

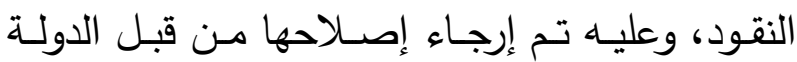
العثمانيــة بـــبب المصــروفات الكثيـرة والمكلفـــة للترميم (r) وعلـى هــا النحــو اسـتمرت معانـاة الأهـالي فـي الحصول على المياه العذبة، وفي حال توفرها فإن

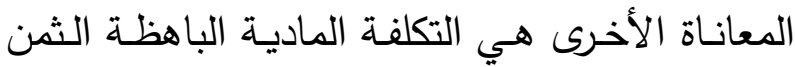
للحصول عليها والتي لا يستطيع الجميع دفع ثمنها.

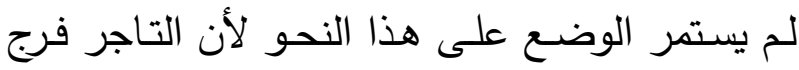
يسر عـاد مـن سفره مـن الهند، وبعـد عودتـهـ عـام

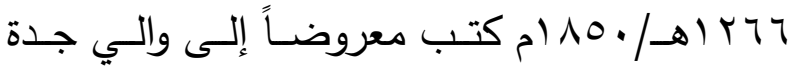

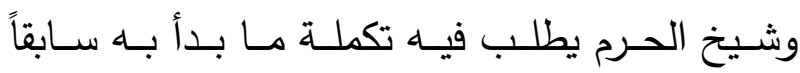

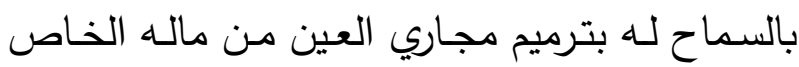

(1) (السرورية: حالياً أحد أحياء منطقة الخمرة الو اقعة جنوب جدة.

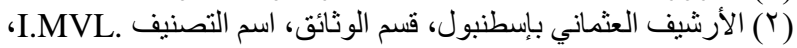

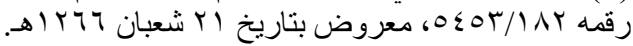


له(r)، كما منحته الدرجة الرابعة من الرتبة(؟)، وذلك بعـد أن تقـدم الشـريف عبـد الله باشـا(ْ) أميـر مكـة المكرمـة بطلب منح فرج يسر الوسـام المجيدي من الدرجة الرابعة نظير خدماته الجليلة للخزينة(؟). ومـن الجدير بالذكر أن بعض المؤلفـات(v) أثـارت إلى أن التاجر فرج يسر كان لله شريك أو معاون في

(T) الأرشيف العثماني بإسطنبول، قسم الوثائق ، اسم التصنيف

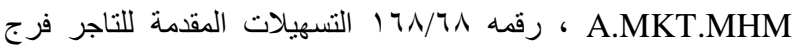

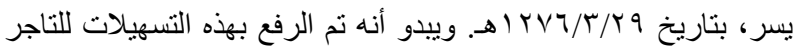

ثم صدرت له بعد ذلك، في وقت لم يكن فيه متو اجداً في مدينة جدة. ( ) الأرشيف العثماني بإسطنبول قسم الوثائق ، اسم التصنيف I.DH

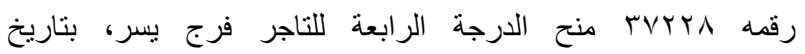
I TVO/T/KT (0) الشريف عبد الله باثا بن محمد بن عون، ولد في مكة المكرمة عام

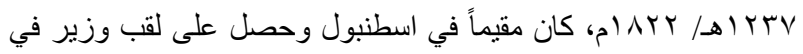
النظام العثماني وهو أول شريف يحصل على درجة وزير، عُرف عنه إجادته للغات التركية والفارسية وقد أرسلته الدولة العثمانية إلى الحجاز

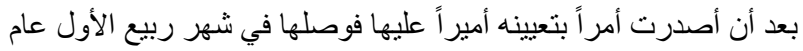

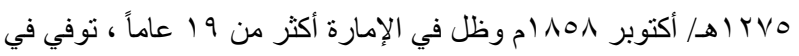

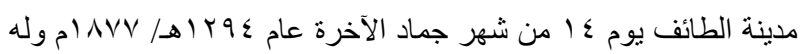

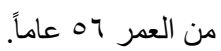
انظر: دارة الملك عبد العزيز، مركز تاريخ مكة المكرمة، قسم الوثائق وثيقة رقم VY · l، " بثأن "متعلقات المرحوم الثريف محمد بن عون

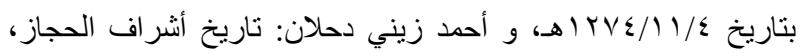

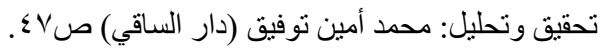

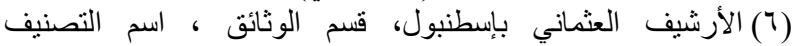
A.I.MKT.NZD

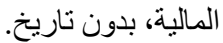

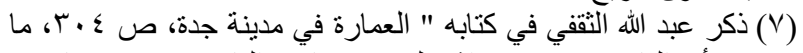

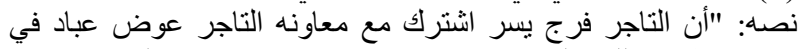

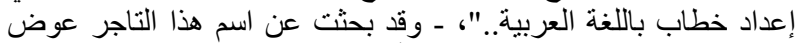

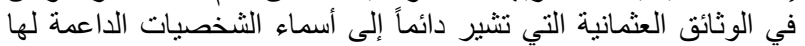

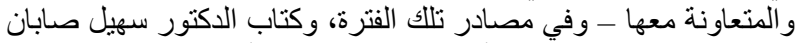

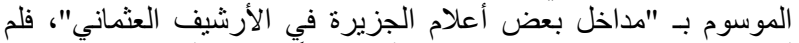

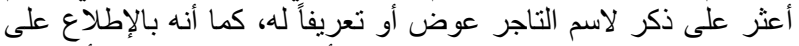

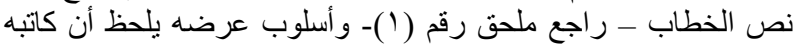

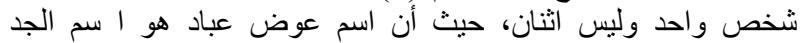
والأسرة للتاجر فرج يسر أي أن اسمه الرباعي هو "فرج يسر عوض هوض
العدــال عنــده لإنهـاء البنـاء الـذي كـان يقـوم بــهـ

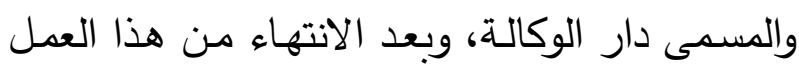
قام والي جدة بالتواصل مع التاجر فرج يسر مقدماً له

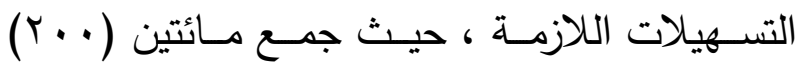
عامل من خيرة العمـال ونصبت لهم الخيام بجوار

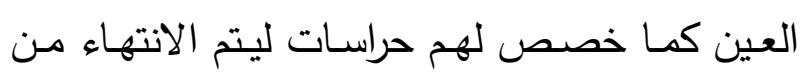
العمل قبل موسم الحج، وذلك خدمة منـه للتاجر فرج

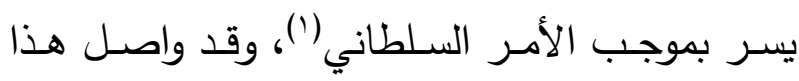

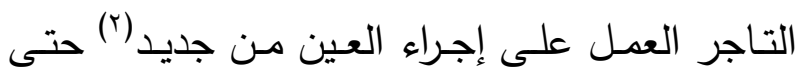

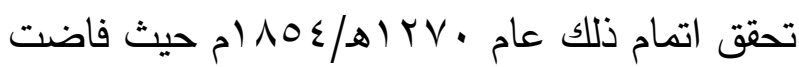
مياهها إلى جدة ونعم الأهالي بتوفر المياه العذبة في مدينتهم سنوات عدة، ومن أجل هذا العمل الإنساني

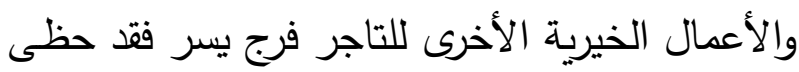

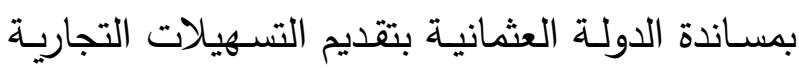

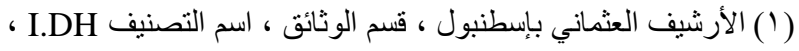

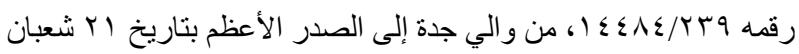

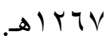

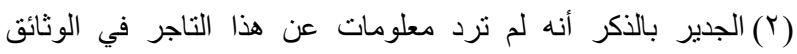

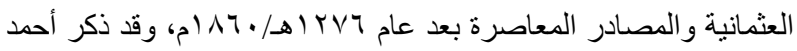

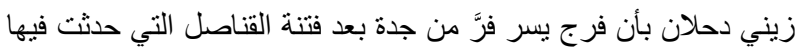

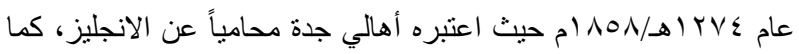

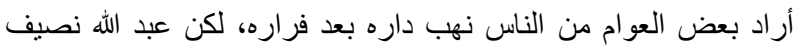

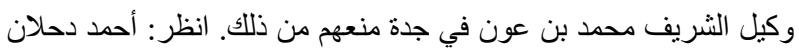

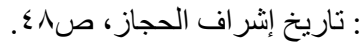

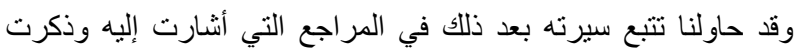

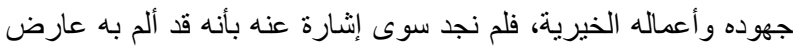

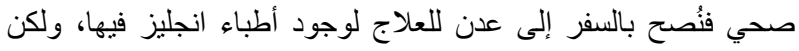

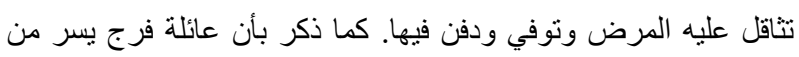

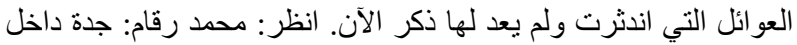

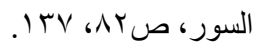


"أردنا عمارة عين جدة وأحيائها كما كانت سابقاً في

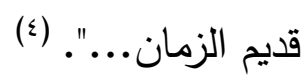

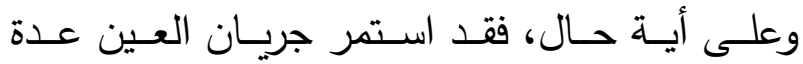

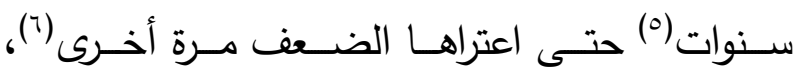
واتضـــ حاجتهـا إلـى التـرميم بعـد خمسـة عشـر

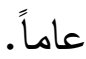

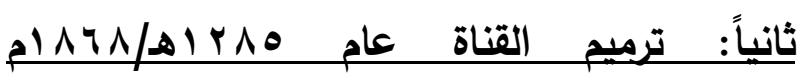
ومحاولات التاحر سليم سلطان:

حين توقف جريان الماء من العين نهض البعض لترميمها وإعادة جريان الماء منها، فقي عام

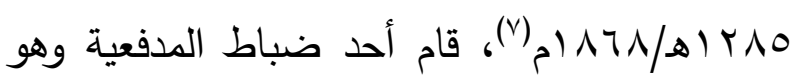
محمد جاويد آغا، والملازم محمد عارف آغا، بترميم مجرى ماء العين الذي تعطلت أجزاء منه، وتقديراً لجهودهما أرسل صاحب الدولة والي الحجاز وقائد الفرقة العسكرية يطلب ترقيتهما، ومنحهما الوسام

فيما يُعرف اليوم باسم قويزة وعلى بعد اكم شمال الجسر المؤدي إلى الى الئ

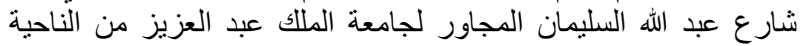

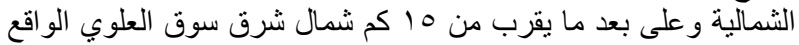

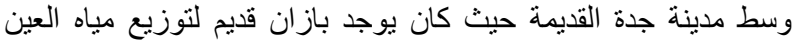
عُرف باسم "عين فرج يسرة

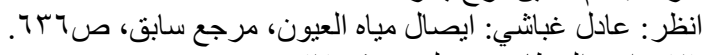

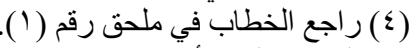

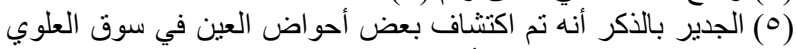

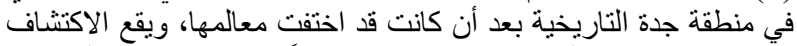

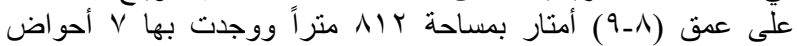

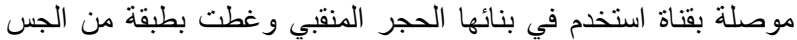

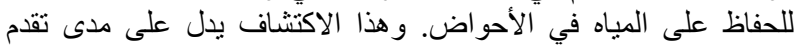
العمارة بجدة من خلال الوسائل والطرق الهندية الهية ومواد البناء المحلية

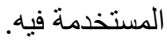

انظر : محمد طر ابلسي: جدة حكاية مدينة (الطبعة الثالثة، جدة/ كتبة كنوز

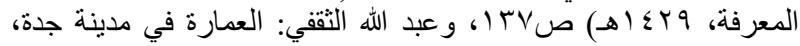

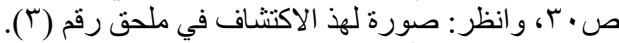

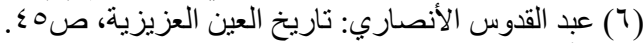

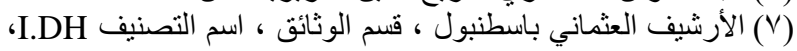

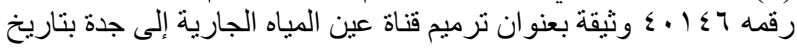
ه 1 ( $110 / 4 / 19$
هذه المبادرة، كما أشار بعضها(') إلى أنه قام بجمع اعانات ومساعدات مالية من الأهالي لإجراء العين،

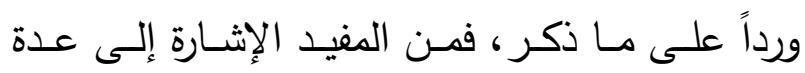

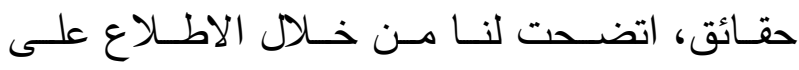
معروض التاجر فرج يسر الذي رفعه إلى والي جدة بطلب ترميم العين، وهي كالتالي: أن إجـراء عين وادي قوز التي قام بها التاجر فرج يسر ، كانت بمبادرة شخصية منسه، فلم يكن لـه شريكُ أو معاونٌ لله في هذه المبادرة.

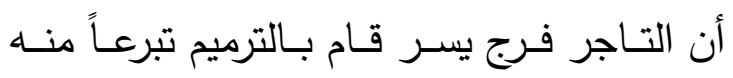

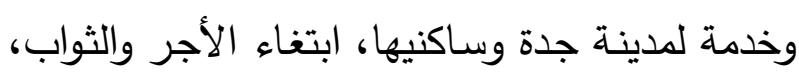
ولم يقم بجمع إعانات أو مساعدات من الأهالي، ولو أن التاجر فرج يسـر قـام بجمـع إعانـات أو تبرعـات مالية من الأهالي لعمل الولاة العثمانيون على حصر أسماء المتبرعين ومقدار الأموال التي تبرعوا بها، فقد عُرف عـنهم حرصـهم على توثيـق كافـة الأمسور

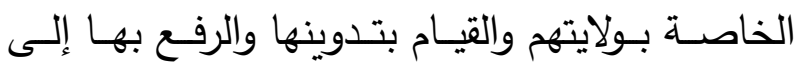
(r) السلطنة. لـم يُــكر في المعـروض موقـع العين (r) التي

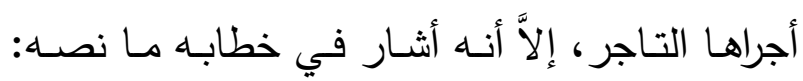

عباد"، لأن هذا الاسم مكتوب في الختم الخاص الذي وقع به التاجر

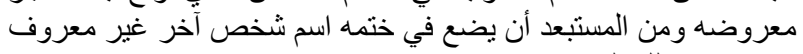
في مصنادر تلك الفترة. ( ) أ) ومن هذه المؤلفات:

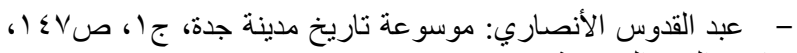

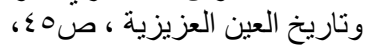

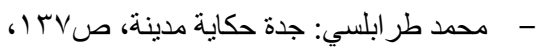

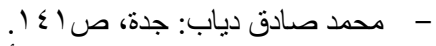

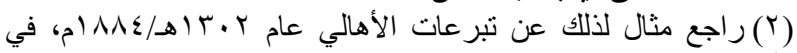

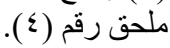
(r) يقع موضع العين بالقرب من آثار القناة الظاهرة على سطح الأرض 
عدة مراسـلات من البـاب العـالي إلى ولايـة الحجـاز

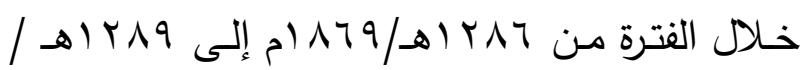
(घ) م) $\wedge \vee Y$

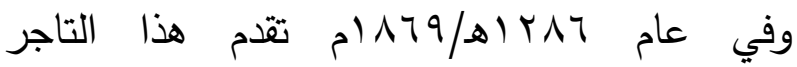
بمعروض إلى والي الحجاز معمر باشا(ث)، يتضمن

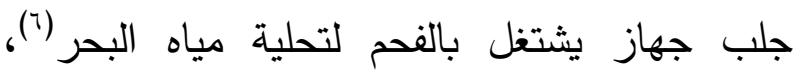

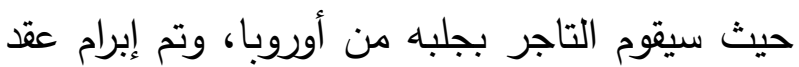
بين مجلس إدارة ولاية الحجاز والتاجر سليم سلطان لثراء الجهاز وبموجب هذا العقد، قامت الدولة العثانية بمنح التاجر أرضاً حكومية خالية مجاناً، تقع بجانب البحر ومساحتها ثلاثة آلاف ذراع مربع، والموقع المخصص لوضع الجهاز أو آلة تحلية مياه البحر هو شمال جدة وعلى مسافة عشرون دقيقة من وسط المدينة، وقد مُنحت للتاجر بعقد مدته خمسة وعشرون عاماً، كما تم الاتفاق على منح الامتياز للتاجر شخصياً ولا يجوز أن يوكل با، غيره(') ويبدو من بنود الاتفاقية ومضمونها وشروطها، أنه كانت هناك مشاورات ودراسات سابقة وعروض قبل التوقيع عليها، استغرقت فترة طويلة قبل عقدها مع التاجر سليم سلطان فالأرض كانت مهيأة للتاجر

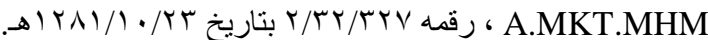

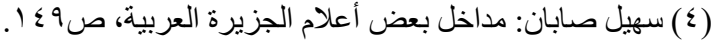

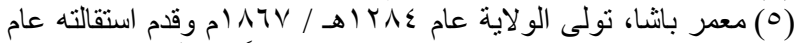

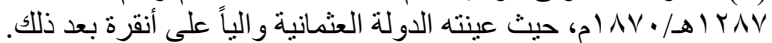

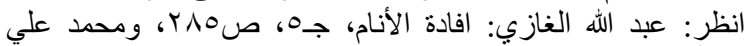

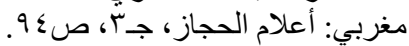
(T) سوف يتم الحديث عن هذا الجهاز في الصفحات اللاحقة.

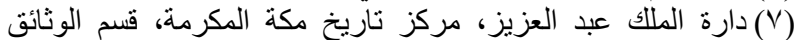

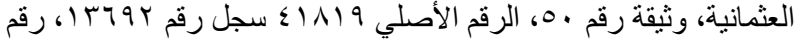

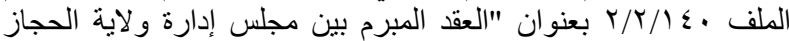

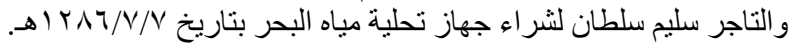

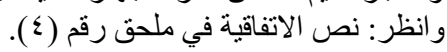

المجيدي من الدرجة الخامسة، ونظراً لأن ترقيتهما تحتاج إلى الانتظار لحين وجود ترقية شاغرة، فإنه

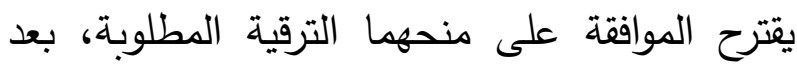
الحصول على إذن من إدارة المدفعية، وقد صدرت لهما الموافقة بمنحهما الوسام المجيدي من الدرجة إنة

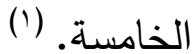
أما العين فقد توقفت عن الجريان بعد ذلك وعادت معاناة الأهالي من جديد من عدم توفر المياه العذبة لديهم.

محاولات التاجر سليم سلطان لتحلية مياه البحر: الثيخ سليم سلطان هو أحد تجار الحجاز المعروفين

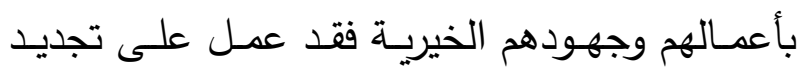
زاويـة للتدريس في مكة المكرمـة، وبنـى كُتاباً فوقها

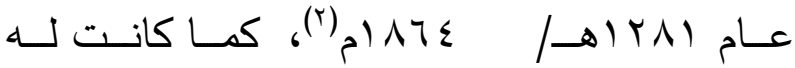
مساهمات تطوعية في مد اقليم الحجاز بما يحتاجها

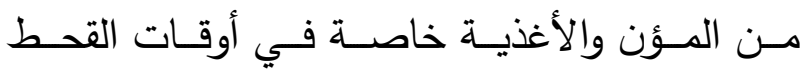
والأزمـات الاقتصـادية، حيث كـان يشتري البضـائع والمؤن الغذائية كالدقيق والقـح من اسطنبول ويقوم بشـنها إلى مدينـة جدة، ولذلك كان يحظى بدعم الدولة العثمانية بالحصول على تسهيلات من الولاية

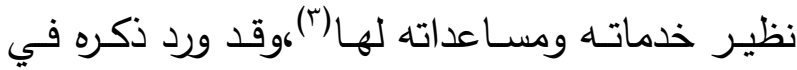

(1) الأرشيف العثماني باسطنبول، قسم الوثائق، اسم التصنيف I.DH

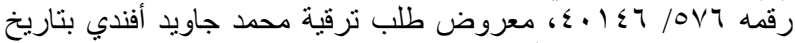

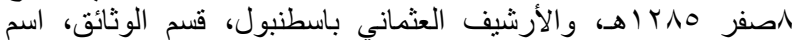

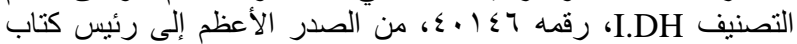

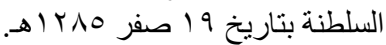

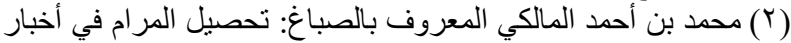

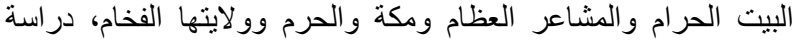

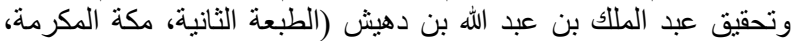

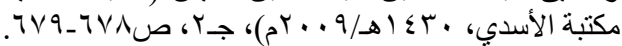

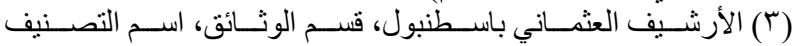


أهالي جدة ومعاناة الحجاج من قلة المياه، فالمصدر الأساسي - وكما هو في السابق - مياه الآبار الغير مـأمون نظافتهـا والصــهاريـج الواقعـة خـارج المدينـة والمملوكة لعدد من التجار الذين يرفعون الأسـعار، فضـلاً عن نضـوب الميـاه بهـا بسرعة، ولذلك تقرر العدـل على إعـادة إجـراء مـاء العـين وبُـده بجمـح الإعانات والمساعدات المالية من الأهالي والتجار (؟)، وقد عُمل كشف بأسماء المتبرعين من أهالي مدينة جدة ومقدار الأمـوال التي دفعهـا كـل شـخص وقد أوضحت وثيقة عثمانية اشتملت على هذه المعلومات

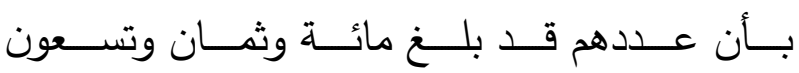

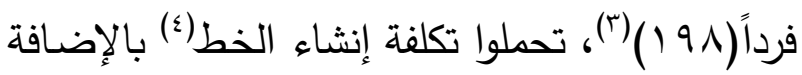
إلى ما تم تحصيله من أموال من خزينة الدولة، ومن الإمــارة، وإعانـات مـن أهـالي مكـة المكرمــة وجـدة،

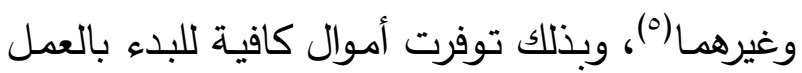
بهذا المشروع الذي أشرف عليه الوزير عثمان نوري

انظر : محمد فريد بك المحامي: تاريخ الدولة العلية العثمانية، تحقيق

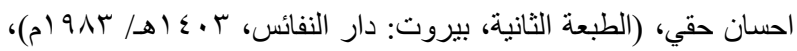
V V V

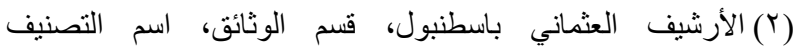

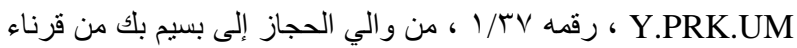

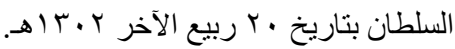

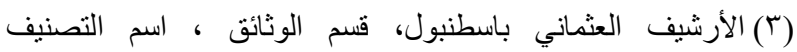

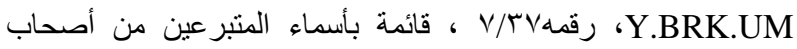

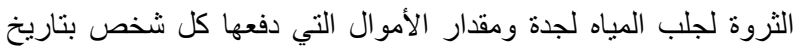

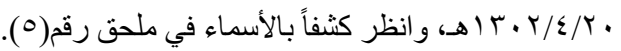

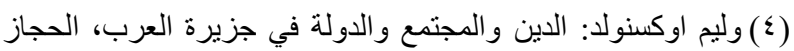

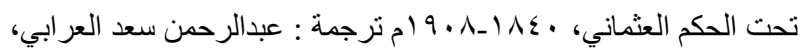

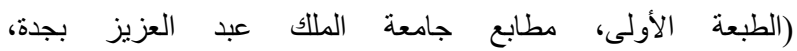

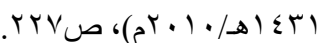

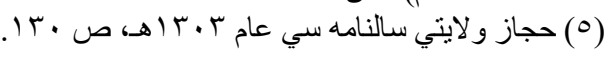

ومساحتها محددة وموقعها معروف، كما ذكر فيها المكان التي سيتم جلب الآلة أو الجهاز منها، وهو أوروبا دون تحديد دولة معينة. أمـا تتفيـذ مـا ورد في هـذهـ الاتفاقيـة والالتـزام ببنودهـا فمن الواضـع أنـهـ لـم يتم جلب هذه الآلة أو هله

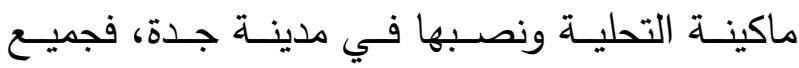
المؤلفات المعاصرة لهذه الفترة لم تشر إلى وجودها، بل كان الأهالي يحصلون على المياه من الصهاريج والعيون، مما يؤكد عدم استخدامها آنذالى، حيث يبدو أنه تعثر تنفيذ الاتفاقية ولم تخرج إلى حيز الوجود أو لون التطبيق الفعلي لاستخدامها، كما أنـه لم ترد الإشارة إلى الاتفاقية في المؤلفات المعاصرة لتلك الفترة ولم

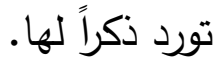
أما التاجر سليم سلطان، فقد حاولنا تتبع سيرته بعد ذلك، فلم نجد ذكراً له، حيث توقفت الوثائق العثمانية

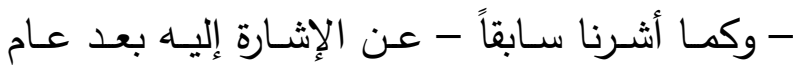
.

ثالثاً: العين الحميدية " الوزيرية"، ودعم أهالي جدة في انشائها:

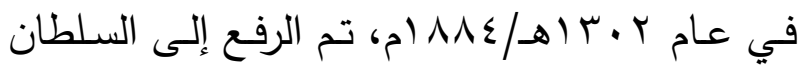

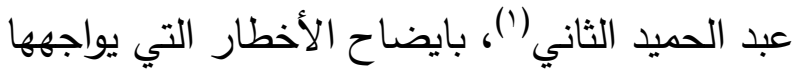

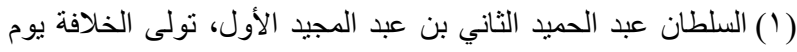

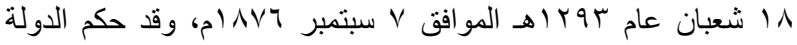

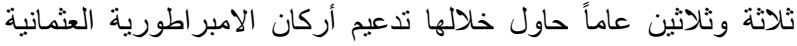

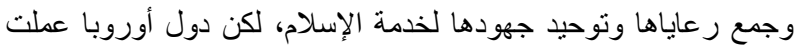

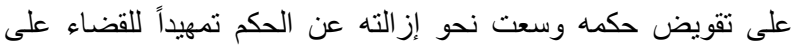
الدولة العثمانية، وقد مر عهده بأحداث متعددة انتهت بعزله عن الخلافة

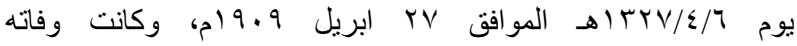

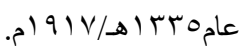


أفندي بمنحـه الوسـام المجيـدي نظيـر حسـن أداءه وجهوده في تأسيس العين (०). الجدير بالذكر أن بعض المؤلفـات أشـارت إلى أن هـذه العـين تقـع قـرب مشـروع اسـكان الأميـر فـواز الشـمالي، يمين الطـالع على الكوبري الموصـل إلى حي الأمير عبد المجيد النموذجي وأنها ليست بالعين السابقة التي قام التاجر فرج يسر بإجراءهـا(`)، إلا أن

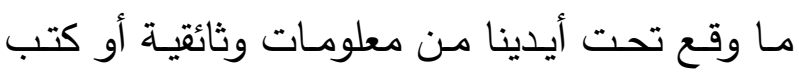
مصـادر أوضـحت لنـا أن هذه العين التي تم إجـراء المـاء منها، هي نفسها عين وادي قوز ، وهي العين التي رممها التاجر فرج يسر، ثم رممت بعد ذلك عام

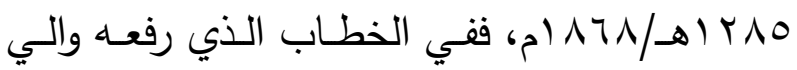
جدة والخاص بترميم العين ذُكر ما نصه بأنه " تقرر العمـل على إعـادة جربـان المـاء مـن نفس المصـدر

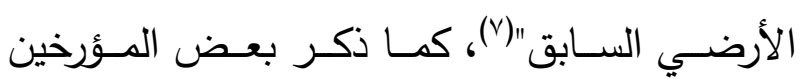

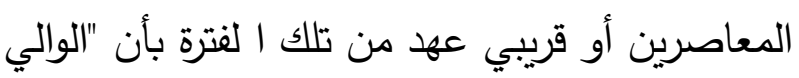
عثمان نوري باشا قد "بذل جهوده لإتمام إجراء الماء من عين الماء القديمة في الرغامـة والتي توقفت عن

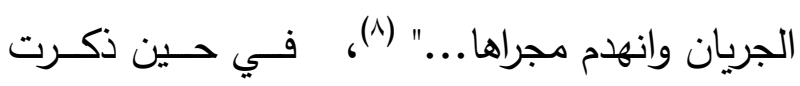

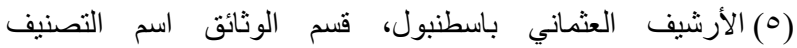
DH.MKT

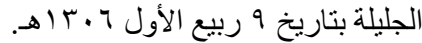

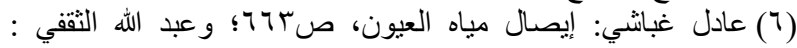

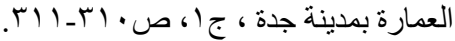

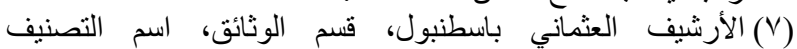

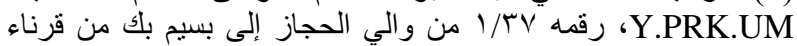

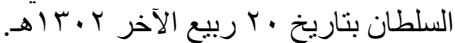

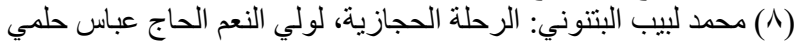

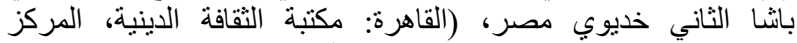

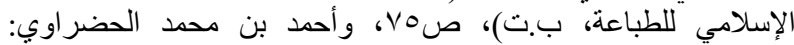

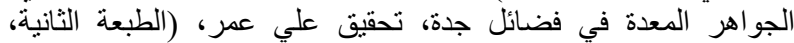

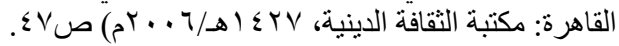

باشا(')، ثم أكمل خلفه الوالي جميل باشـا (广) مواصلة الاهتمام به، فأولاه مزيداً من المتابعة وأظهر حماساً في حله، لكن هذا الوالي لم يستمر في ولايته، وتولى لهرله

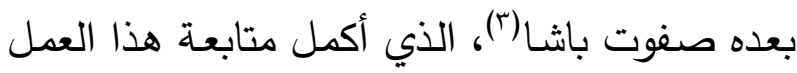
بعد أن عايش المشكلة عن كثب وقام بشق مجاري

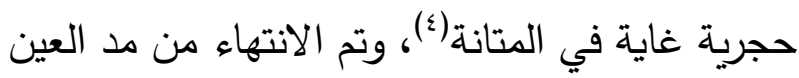

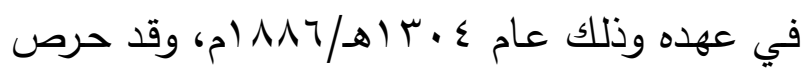
هذا الوالي على تكريم من كانت لله جهود ومساهمات ونات في اتمـام هذا المشـروع فكتب إلى نظــارة الداخليـة بطلب تكريم رئيس بلديسة جدة عبد الكريم حبيب لفئب

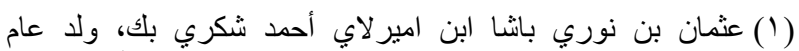

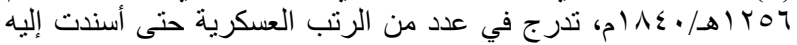

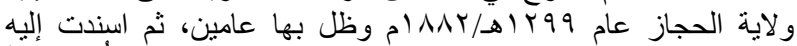

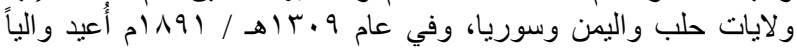

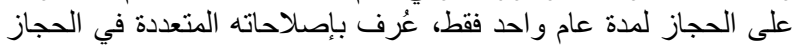

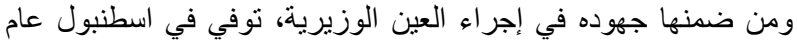

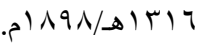

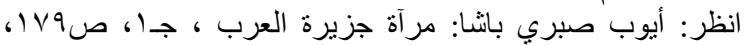

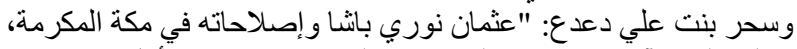

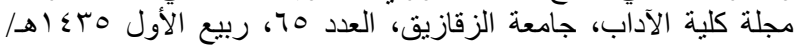
(Y) - (T)

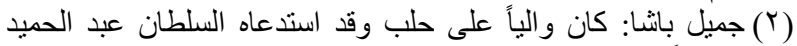

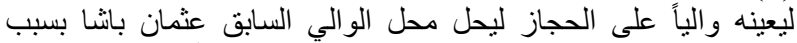

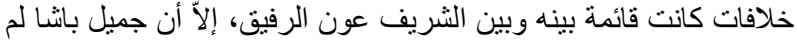

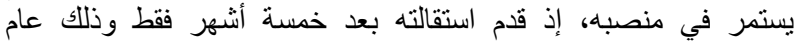

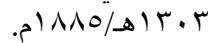

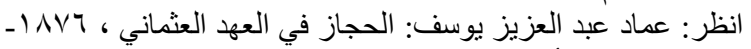

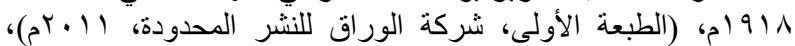

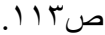

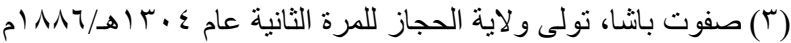

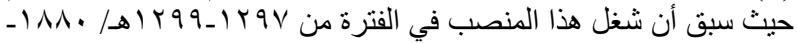

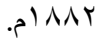
انظر : سنوك هورخورنيه: صفحات من تاريخ مكة نقله إلى العربية :

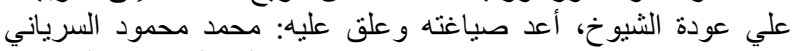

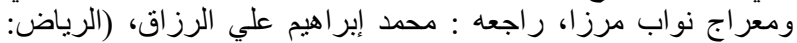

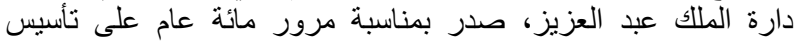

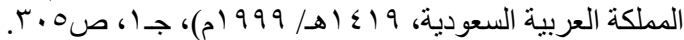

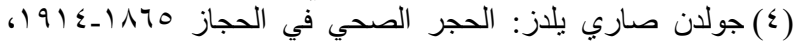

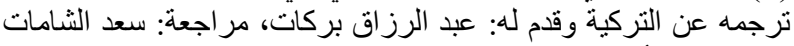

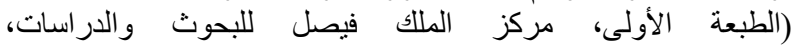

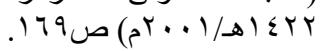


كثب لهذين الموقعين (ז)، ويبن مـا وقع تحت أيدينا مـن معلومـات أوردناهـا في الأسـطر السـابقة يتبـادر إلى الذهن بأنه من الممكن أن يكون منبع العينين

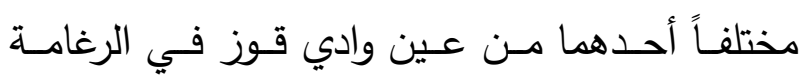
والآخر من العين الأخرى الواقعة قرب مشروع اسكان

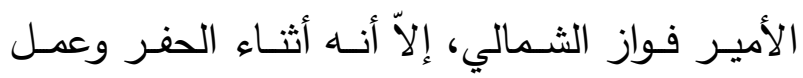
التمديـدات لســب الميـاه مـن الموقـع لايصـاله إلىى إلى وسـط جـدة، تمــت الاسـتفادة مـن المجـرى السـابق والقريب من مركز العين في الرغامـة، حيث يحتمل أن المجرى الجديد(ء) قد رُبط به لتقليل الجهد والوقت والمـال والمسـافة، وأن مـا ذكر في الوثيقـة العثمانيـة وفـي بعـض المصــادر التـي أوردناهــا بأنــه نفس ولس المصدر الأرضي السابق قد تم الاستناد فيه على ما شـوهد لمجـرى العين ومصبها في الأحـواض داخل الــل مدينة جدة وفي محيط أسوارها فقط(ن). وقد عُرفت هذه العين باسم العين الوزيرية نسبة إلى الوزير عثمان نوري باشا الذي بُدء العمل بها في ولايته، ثم سميت بالعين الحميدية نسبة إلى السلطان

عبد الحميد الثاني (־).

(T) راجع تفاصيل ذلك في: عادل غبانشي: إيصال مياه العيون، مرجع

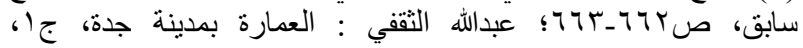

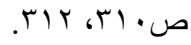
(ع) انظر تصور لهذا الر أي في الخريطة بملحق رقم (7).

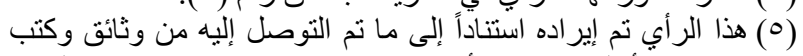

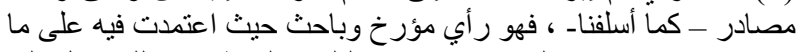

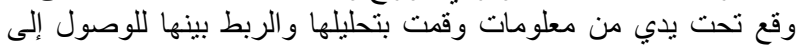

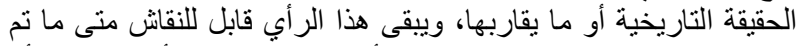

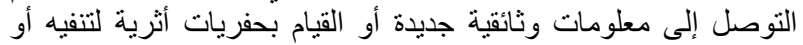
لتؤكده. (T) عبد القدوس الأنصاري: موسو عة تاريخ مدينة جدة، ج ا، صلV أ.
أحد المؤلفات المتخصصـة عن المياه في جدة

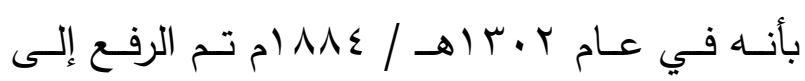

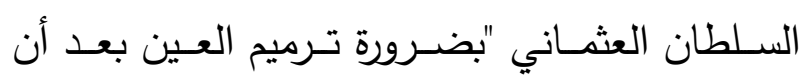

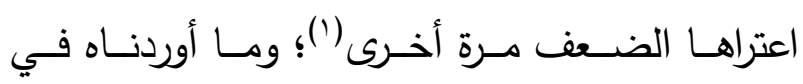
الأسطر السابقة يوضـح أنه لم يتم طلب البحث عن عين ماء جديدة، أو موقع آخر بديل، ولكنها جميعها تحدثت عن العين السـابقة وترميمها لإعـادة جريـان المـاء فيها، وقد رأيت الرجوع إلى جغرافيـة المنطقـة لمعرفـة منـابع العيـون ومجـاري الأوديـة في أبـرق الرغامة والعين الأخرى التي ذُكر أنه تم سحب المياه منها في المرة الثانية ومعرفة سير مصبها في جدة التاريخيـة بأخذ رأي المتخصصـين الجغـرافيين، وقـد ذُكر لي بأنـه لا يمكن معرفـة مجـاري الأوديـة حالياً

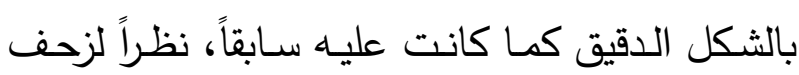
المبـاني وبنـاء السـدود وشـق قنـوات التصـريف وهدم وردم بعض الأمساكن، مدا أدى إلى تغير طبوغرافية الأرض وبالتالي صعوبة استتتاج مجاري الأودية قبل توسـع وانتشـار البنـاء، حيـث يتطلـب معرفـة ذلك الرجوع إلى البيانات الجوية والفضـائية والتي لـ تكن

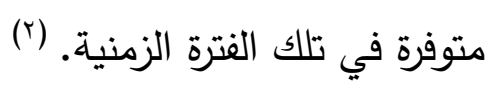
وفي محاولة للتوفيق بين مـا ذكرته بعض المؤلفات والتي استندت في ذلك إلى جولات ميدانية وزيارة عن

(1) عبد القدوس الأنصاري : تاريخ العين العزيزية، ولمحات عن مصادر المياه في المملكة العربية السعودية، (طبع على نفقة إدين إدارة العين العزيزية العزية

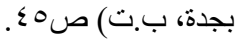

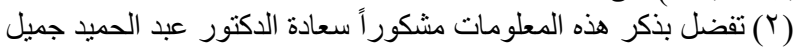

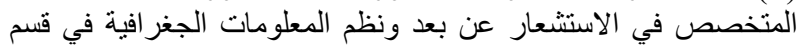
الجغر افيا ونظم المعلومات الجغر افية بجامعة الملك عبد العزيز. 
الحواري، بحيث يتكفل سكان كل حارة بحفر وتمديد المواسير عبر حواريهم، ولدى انتهاء كل حارة من

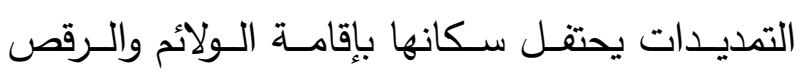
الشعبي والغناء (V)، فقد كان إجراء هذه العين مصدر

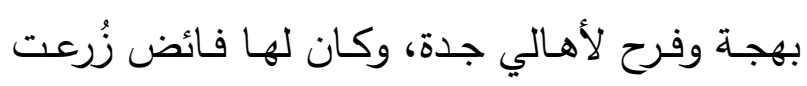
عليـه حدائق غنـاء وبـرك في أحيـاء المدينـة لنزهـة

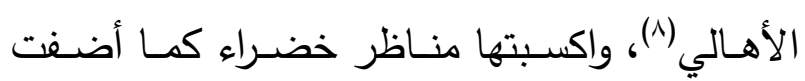
عليهـا بهجــةً وجمـالاً حيــث يتجمـع السـكان رجـالاً

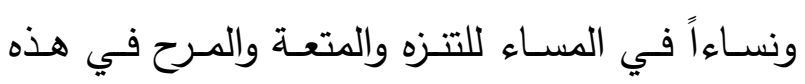
الحدائق (9). وبذلك كان الانتهاء من إجراء العين الحميدية آنذاك مصدر راحة لأهالي جدة وساكنيها، حيث توفرت لهم احتياجـاتهم مـن الميـاه العذبـة التـي عـانوا لسـنوات طويلة في سبيل توفيرها، لكن هذا الوضـع لم يستمر طويلاً، فقد تعطلت العين بعد عام واحد من الانتهاء من جريانها، وتم إصـلاحها، ثم تعطلت بالكامل بعد

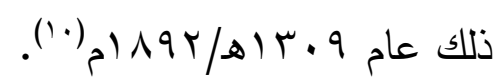
وبعد توقف العين، جرت مفاوضـات ومراسـلات بين ولاية الحجاز والسلطنة العثانية في اسطنبول للعمل على إصلاح الأعطال، إلا أن ميزانية الدولة لم تكن

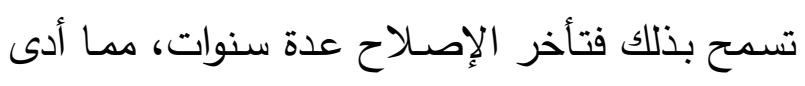

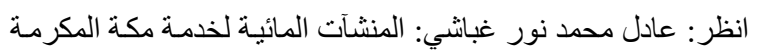

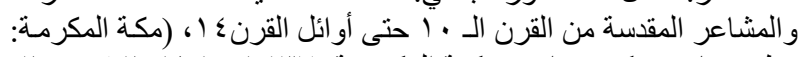

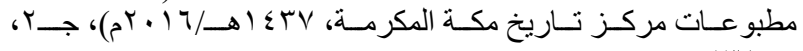

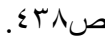

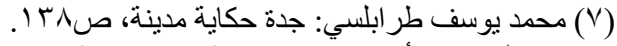

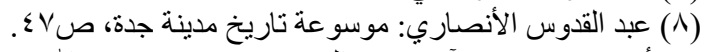

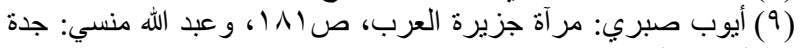
في التاريخ الحديث، صبري: مرآ جزيرة

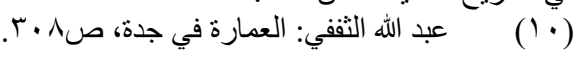

أما تنظيم العين وطريقة توزيع المياه فيها، فقد

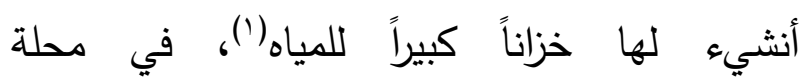
العيدروس(r)، وهذا الخزان ينتهي بعدة أسبلة لخدمة

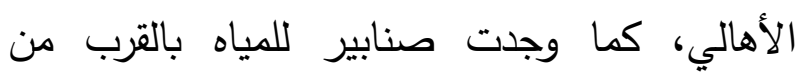
المستثفى العسكري، وحوض كبير في المستشفى

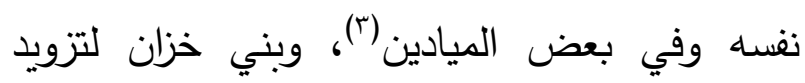

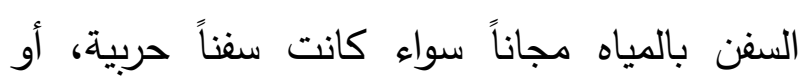
غيرها من السفن الراسية بالميناء بالمياه مجاناً، وقد

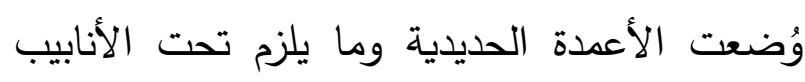

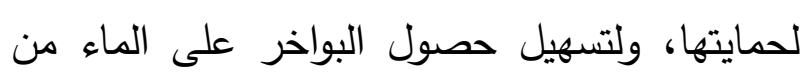
الأنبوبة الممتدة إلى البحر (๕). وفي ميدان الميناء كان هناك عين ماء مثنة الثكل الثيل تحمل اسم الخليفة السلطان عبدالحميد وسطها نافورة

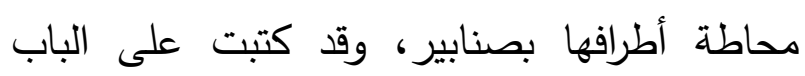
الثمالي للعين أبيات من الثعر دُون عليها تاريخ

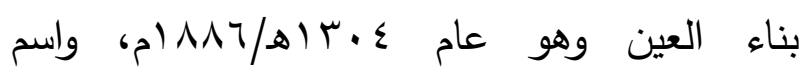
السلطان العثماني الذي أجريت العين في عهده(ه).

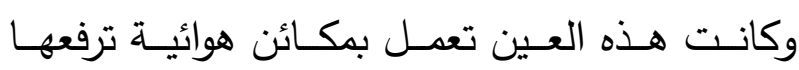

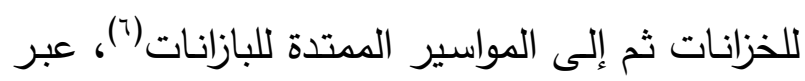

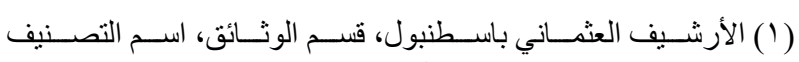
DH.MKT

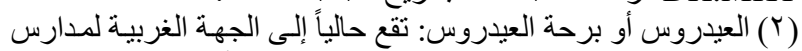

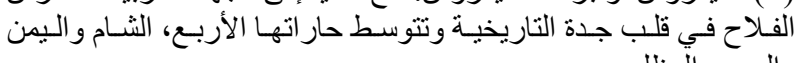

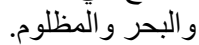

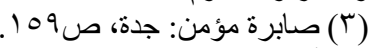

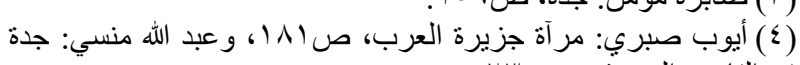

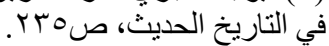

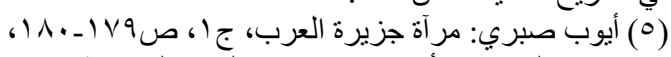

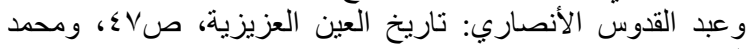

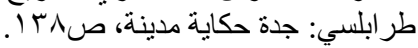

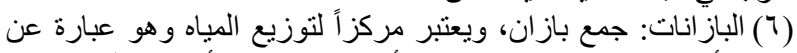

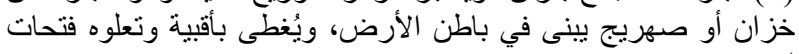


بأنـه على الرغم من توفير المياه بجدة بشكل مؤقت إلاَّ أنـه مـن الضــروري تـرميم كافـة المجـاري المائيـة الموجـودة بهـا(؛) أو إرسـال آلـة تقطير كبيـرة تـوفر خمسين طنـاً مسن الميـاه يوميـاً؛ على أن ذلك كـان بحاجـة لمبـالغ ماليـة تقدر بحوالي تسـعة آلاف ليـرة وحيث أن هذا المبلغ غير متوفر فقد طلبته الصدارة مـن عائدات الصـحة على سـبيل القرض واضـافته على حسـاب خزانـة الماليـة، لكن المجلس الصـحي أرسل معتذراً عن عدم تمكنه من تأمين هذا المبلغ، كمـا لـم يسـتطع البـاب العـالي حسـم القضـية بسـبب الضـائقة الماليـة التي كـان يعانيهـا، فلم يـمكن مـن جلب آلتة التقطير وتأخر توريدها عدة سنوات، في وقت كانت ميـاه العين الحميديـة قد نضبت - كمـا أسـلفنا-، ممـا أدى إلى ارتحـال بعض الأهـالي إلى اهى مكة والطائف، كما اضطرت كتيبتان عسكريتان كانتا موجودتان في جدة إلى الانتقال نحو مدينـة الطائف كذلك (0). وعلى هذا النحو، اسـتمر نقص الميـاه العذبـة في مدينة جدة، رغم المحاولات المتعددة لتوفيره، إلاَّأنها محاولات لم يكتب لها النجاح التام في إنهاء معاناة الأهالي والوافدين من نقص المياه وشحه في معظم الأوقات، حيث كان يتطلب توفيره مبالغ مالية ونفقات ومصـروفات باهظــة فـي وقـت كانــت فيــه الدولــة

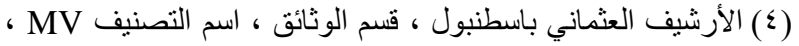

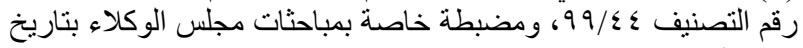

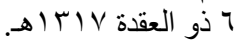

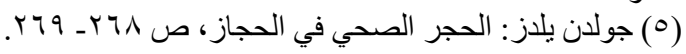

إلى تفاقم أزمـة نقص الميـاه ولذلك قامت الدولة في عـام 7 اب اهـ/199 (م بشـراء سـفينة قـاطرة لنقـل الحجـاج القادمين إلى جدة إلى جزيـرة أبي سـد (')،

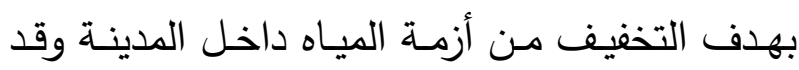

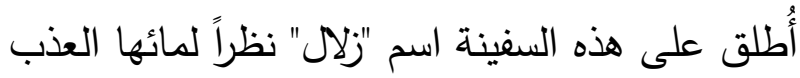
الرائق البارد الخفيف، حيث توفر خمسـة أطنان من

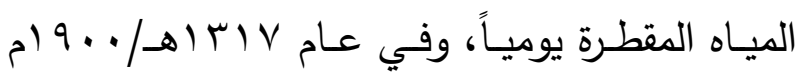
هطلت الأمطار على جدة بغزارة وذلك في أول أيام عيد الفطر ، فملأت نصف الصهاريج وقد سـاعد ذلك على توفر المياه في المدينة آنذاك(؟). ومـن الواضـح أن مـا تـوفر لـم يكـن كافيـاً لتغطيـة احتياجات الأهالي والسكان والوافدين إليها خاصة في

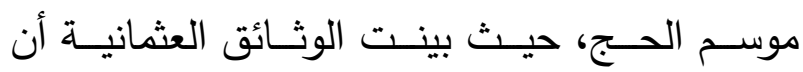
القنصليات الأجنبية في جدة طلبت توفير سفن لجلب المياه على أن تكون حمولة كل سفينة لا تقل عن خمسة وعشرون طناً(ז) وذلك لقلة المياه ولقرب موسم الحج وتزايد وفود الحجاج إلى المدينة، كما أشـارت:

(1 ) جزيرة أبي سعد: وهي جزيرة تقع على مسافة غير بعيدة عن شـاطئ

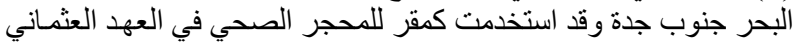

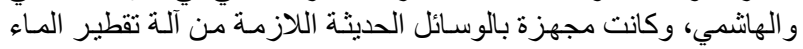

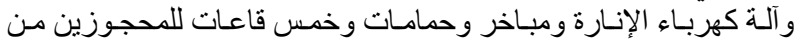

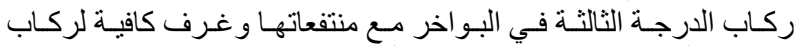

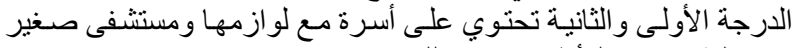

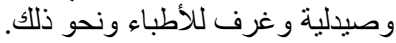

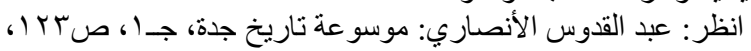
الجدير بالذكر أن هذه الجزيرة قد اندثرت حالياً ولم يعد لها أثر بعد أعمال

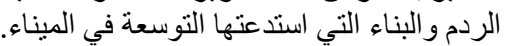

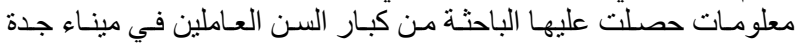

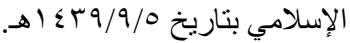

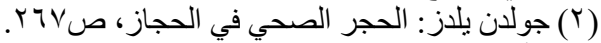

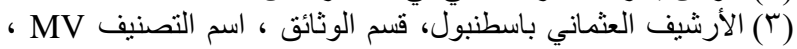

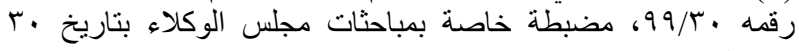

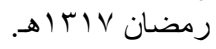


الأمور الصحية قرر عدم صرف القرض طالما أن

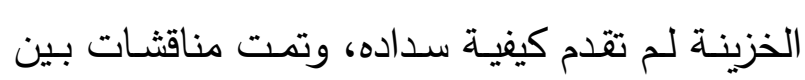
تلك الجهات المختصة تقرر فيه بعدها ضرورة اتخاذ

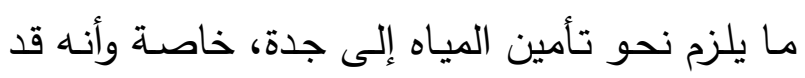

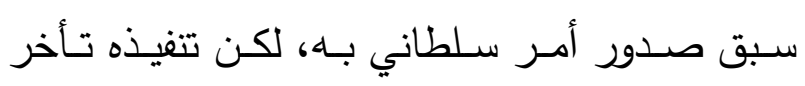

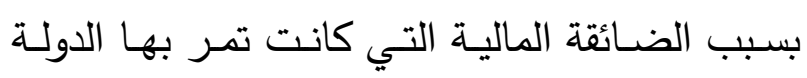
العثمانية، وبعد مشاورات ومداولات، صدر أمر شراء ماكينات التقطير اللازمة والتي كانت على أنواع منها ولتها مـا هـو بمرحلـة تصـفية أو تتقيـة واحدة ومـرحلتين وثلاثة مراحل، وكلما زادت مراحل التصفية أو التتقية زاد سعر الماكينة(r). وفي محاولة من نظارة الصحة لتوفير مبلغ شراء آلة التقطيـر ، فقـــــامـت بدراســة الوضــع المـالي القـائم

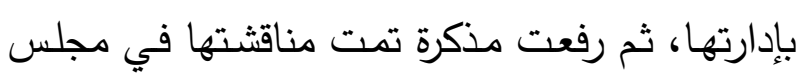

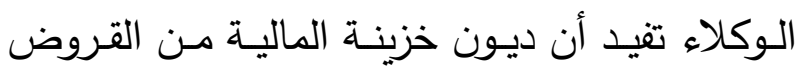

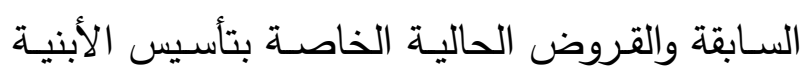
اللازمة لماكينات المياه قد تراكمت وأصبحت مبلغال

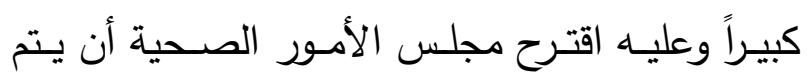

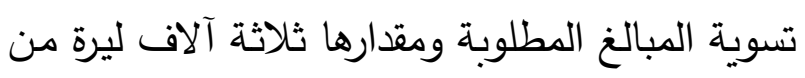

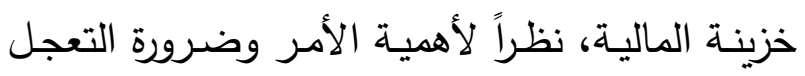
فيه (๕) خزنة

،WV الأرشيف العثماني بإسطنبول، قسم الوثائق، اسم التصنيف (T)

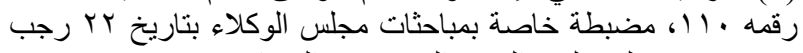

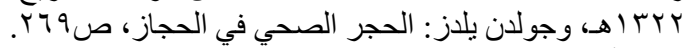

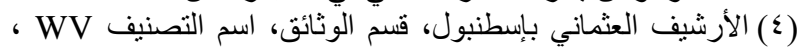

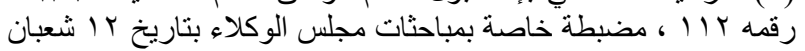

العثمانية تعاني عجزاً مالياً، أعاقها عن الاستمرار في

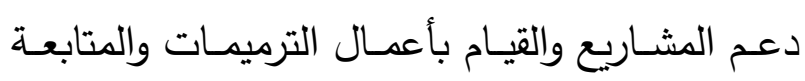
والصيانة. لابعاً: آلة تحلية المياه " الكنداسة":

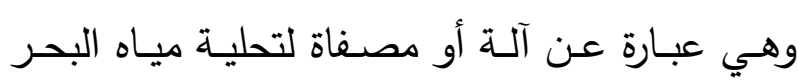

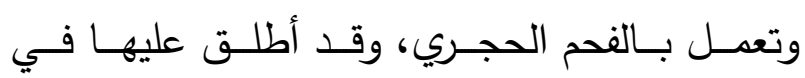
المؤلفـات الحديثة اسـم "الكنداسـة"((') وهذه التســية

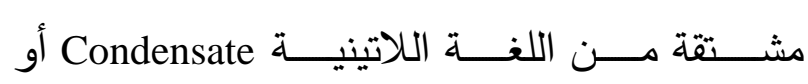
Condensates وكما مر بنا - كان طلب جلب هذه الآلة، مقترحاً

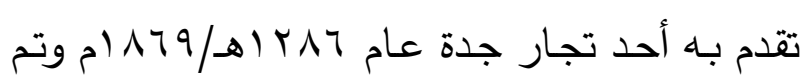

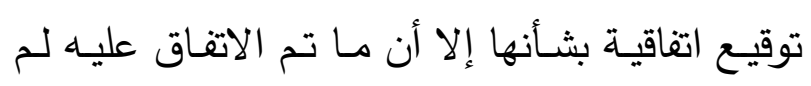
يتحقق في تلك الفترة. ونظراً لاستمرار نقص المياه والحاجة المتزايدة لها،

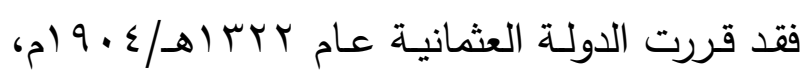

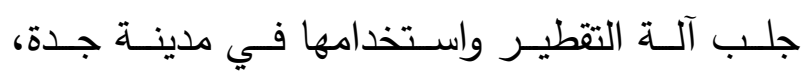

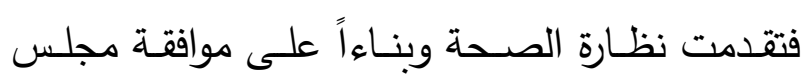
الأمور الصحية بطلب اقراض الخزينـة من واردات

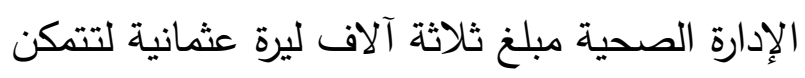

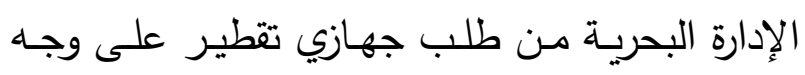

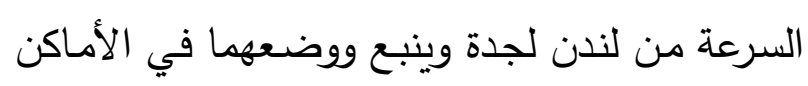

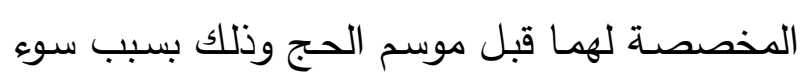

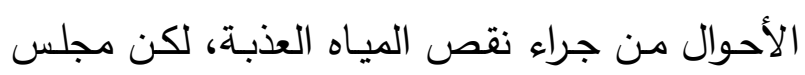

(1) (انظر صورة للكنداسة والأجز اء التي تتكون منها في ملحق رقم (V) (V).

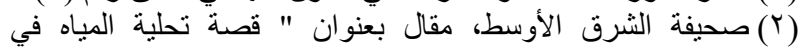

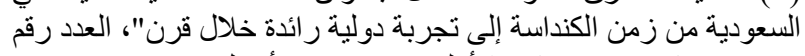

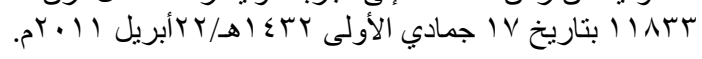




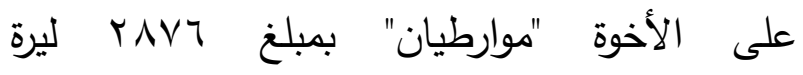

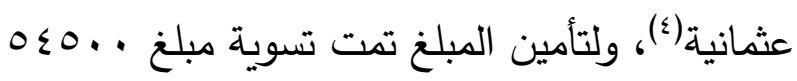
قرش من أجل مصاريف تأسيس الماكينة(ْ)، ودُفع ثمنها من صندوق الإعانات لعين زبيدة(ا) في مكة المكرمة (V). وتم بعدها البدء بالعمليات الانشائية لنصب ماكينة التقطير وأُرسلت الخطة والرسم الذي نفذه المقاول إلى ولاية الحجاز عام هب إهـ / 7 ا9 ام حيث أُنجز تركيبها خلال خمسة وعشرون يوماً(^)، وقد تم نصبها على شاطئ البحر، غرب حارة الثام(") ، بمنطقة تُعرف ببحر الحجر (·')، على شاطئ البحر (').

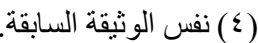

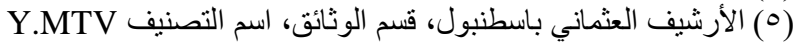

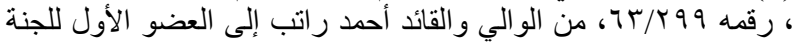

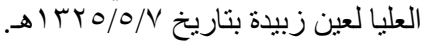

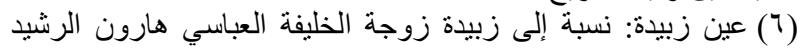

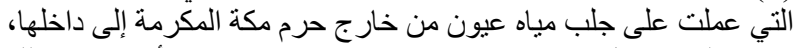

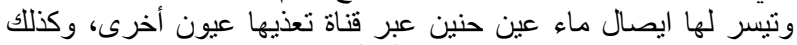

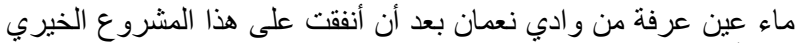

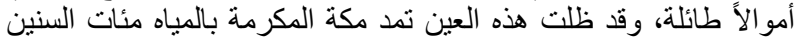

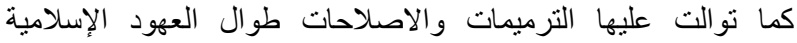
المختلفة.

انظر: عادل بن محمد نور غباثي: المنشآت المائية لخدمة مكة

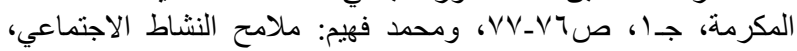

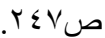

Y.MTV الأرشيف العثماني بإسطنبول، قسم الوثائق، اسم التصنيف (V)

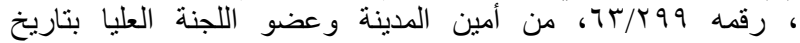


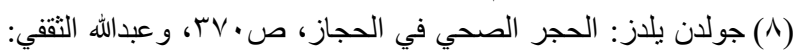

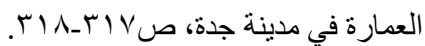

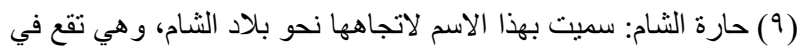

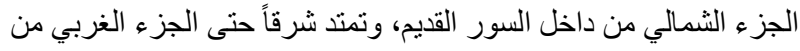

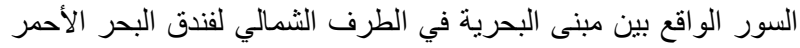

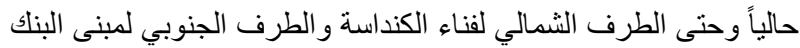
الأهلي في شار ع الملك عبد العزيز. انظر: فيصل حسن البكري: جدة تاريخ وحضارة، (الطبعة الأولى،

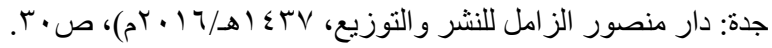

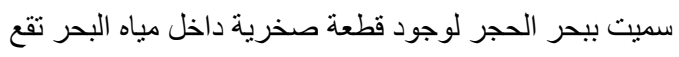

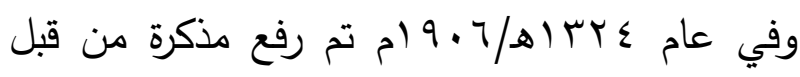

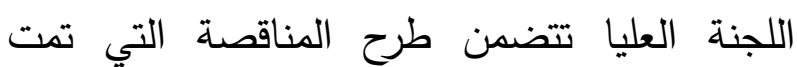

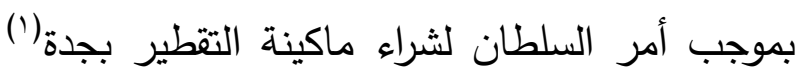
بالإضافة إلى اقتراح ولاية الحجاز شراء ماكينة

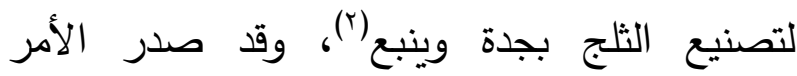
السلطاني بخصوص إجراء التعاقد مع متعهد لشراء

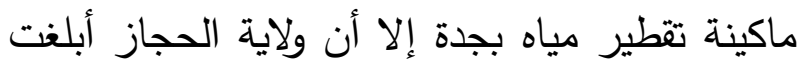

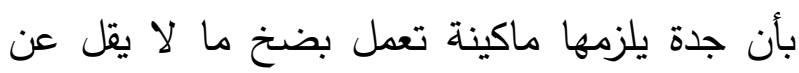

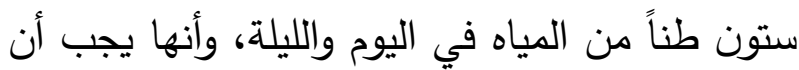

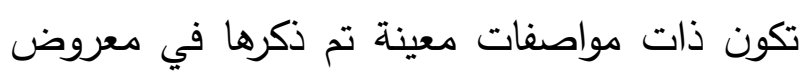
رُفع إلى الباب العالي حيث تضمنت هذه المواصفات ما يلي: مساحة كبيرة لتأسيسها، خزان مياه كبير أيضاً،

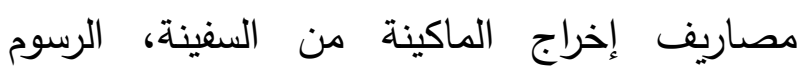
الجمركية، مصاريف الصيانة التي ستتم سنوياً، ثم الثراج هناك مصروفات المواسير والامدادات ونحو ذلك("). وعلى الرغم من صعوبة جلب آلة التقطير بهذه المواصفات إلاّ أن الحاجة الماسة لها، استدعت أن أن يتم البدء في إجراءات جلبها، فتم عمل إعلان في الصحف عن طرح مناقصة لماكينة تقطير ذات ثلاثة مراحل متحركة تعمل بالفحم، ورست المناقصة

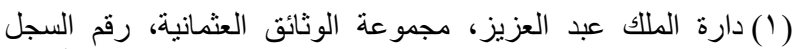

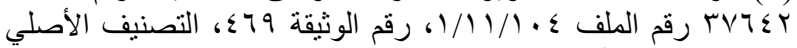
BEO م. $9.7 / \% / \mathrm{T}$

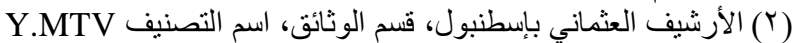

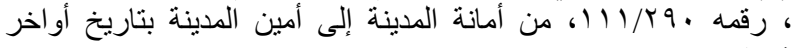

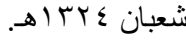

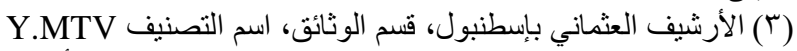

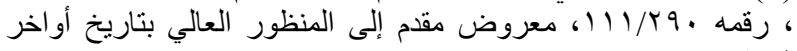
شعبان ع ץ" أهـ. 


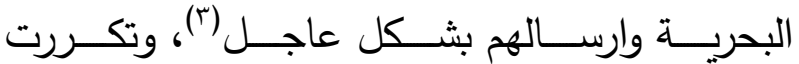
المراسـلات بهذا الشـأن (๕)، حيث كانت الحاجة ملحة لتواجد الفنيين في الحجاز ، خاصة بعد إجراء التجربـة عليها من قبل لجنة ، تبين لها أن هناك فرقاً بين كمية المياه المحلاة وبين أصل ما كان مقرراً ومتفقاً

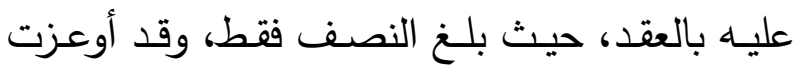
اللجنة ذلك إلى شدة ملوحة مياه البحر، كما لاحظت أن المواسير والمباني الملحقة بالمشروع من أحواض وأسطح وغيرها لم تكن وفق الشروط، فقررت رفض بـ صرف المبالغ المتبقية المتفق عليها(ث). ويبدو أن هذه الآلة لم تكن بالفعل ذات مواصفات جيدة وبحسب ما كان يأمله المسؤولون من فائدة مرجوة من جلبها، لأن ما تتتجه من مياه عذبه لم يكن وفيراً وكافياً لجميع السكان ولم يفِ بالغرض، فبقيت الصهاريج مصدر سقيا غالبية السكان في جدة") ( ) وبذلك لم تكن آلة التقطير هي البديل المناسب لمياه الآبار والصهاريج الذي يُوض مشكلة نقص المياه العذبة، حيث ظلت هذه المشكلة قائمة، في حين واصل الأهالي البحث عن بدائل ووسائل جديدة لتوفير المياه لمدينتهم.

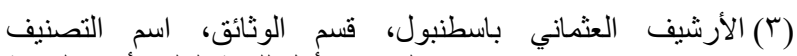

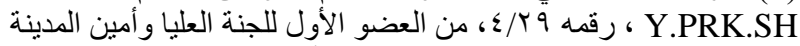

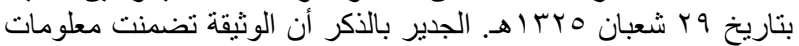
بنصب ماكينة تقطير وتصنيع ثلإن بمدينة ينبع كذلك.

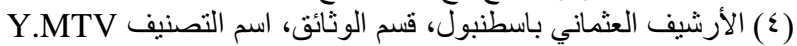

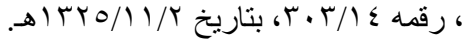

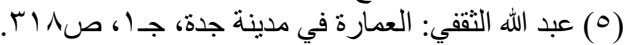

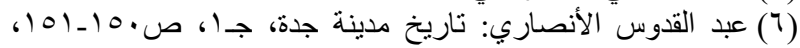

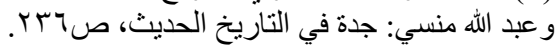

وكان لهذه الآلة مبنى خاص للأجهزة والمعدات، يضم القازانات أو أفران حرق الوقود، والغلايات إضافة إلى أنابيب النقل ومضخات رفع الماء والخزانات وتبدأ عملية تحلية مياه البحر بعد أن توقد القازانات بحطب الثورى، ثم بالفحم الحجري الذي لئاه يحتاج إلى حرارة عالية ليبدأ بالاحتراق وانتاج الطاقة، أما ماء البحر، فقد كان يُنقل للكنداسة بواسطة قناتين

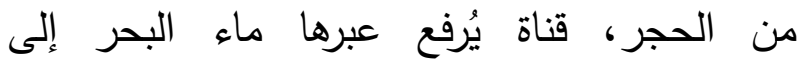
الغلايات، حيث يتم تكريره وتقطيره ويخرج ماءاً حلواً عذباً صالحاً للاستعمال، أما القناة الأخرى فيُطرد منها الماء المالح المنفصل بعد التحلية إلى البحر (r).

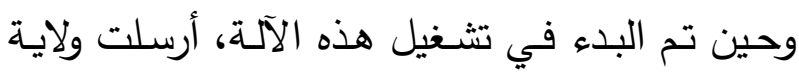
الحجاز بطلب عاجل بضرورة تواجد فني ماكينات

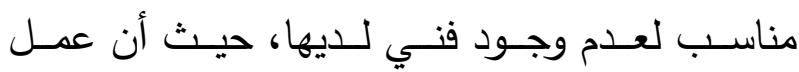
الماكينة بتوفير المياه الصـالحة للشرب يتوقف على ولى

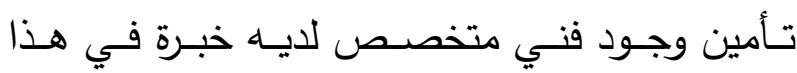
المجـال، وقــــــــت اللجنـة العليـا الخاصــة مــكرة

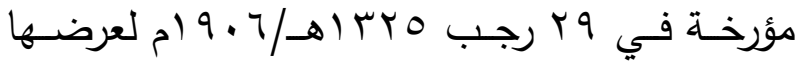

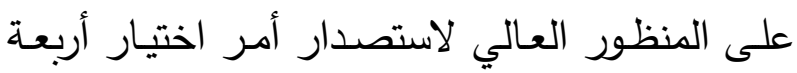
فنيين متخصصين في ماكينات التقطير من الإدارة على مسافة غير بعيدة عن الشاطئ بحيث يمكن رؤيتها بوضوح من اليابسة، والمنطقة حالياً هي التي تقع على بحر الأربعين في موقع البنك

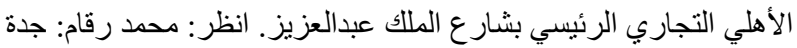

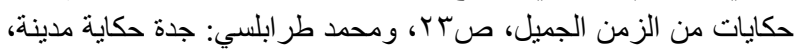

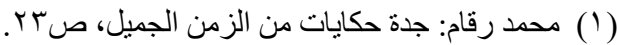

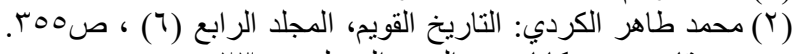

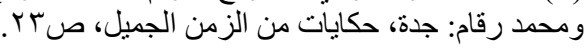


وفيمـا يخص تـاريخ تشكيل هـذه الهيئة، فلم يحدد المـؤرخ الغـازي والـذي ا نفـرد بـذكر هـذه المعلومــة،

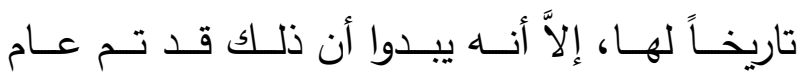

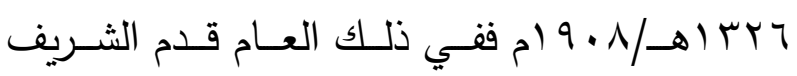
الحسين بن علي(r) إلى الحجاز بعد تتصيبه أميـراً

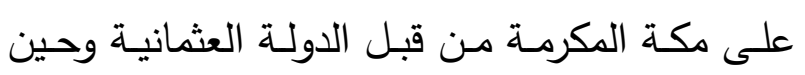
قدومـه، سـمع بالهيئـة ومهامهـا ، فســر كثيـراً بهـا وبأعمالها الوطنية، فتبرع بالقسط الذي يخص دولته من رسم التخريجية ومبلغه قرشان، بأمل تسهيل أمور هذه الهيئة والوصول إلى الهدف المنشود من إنشائها بما أمكن من سرعة آَّان. وفي انتظـار أن تسـتقر أمسور الهيئة الوطنيـة وتبـدأ بممارسـة أعمالها بالتنقيب عن مصسادر للمياه وإلى لى حين ظهور نتائج بذلك، تمت المطالبة بترميم العين الحميدية حيث أرسل الثريف الحسين بن علي في

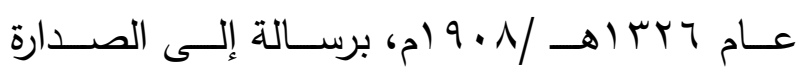
العظمى في اسطنبول يطلب ترميم عين الحميديـة

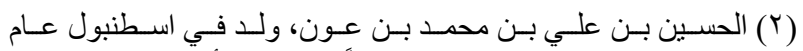

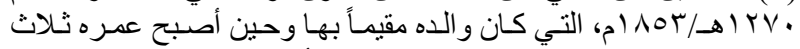

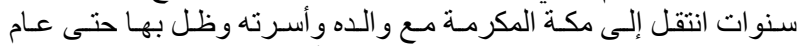

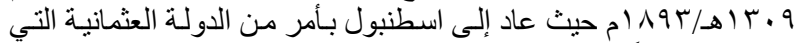

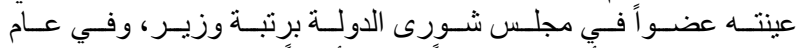

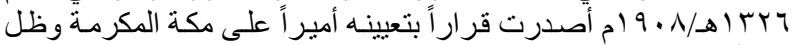

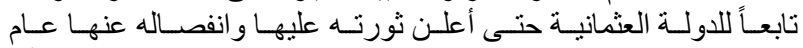

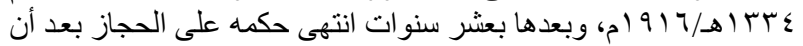

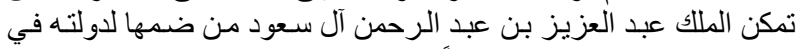

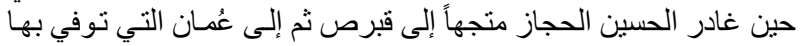

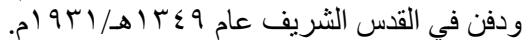

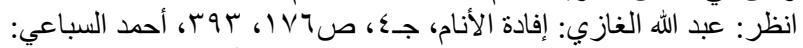

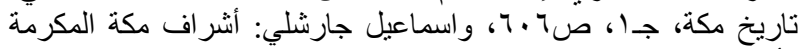

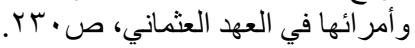

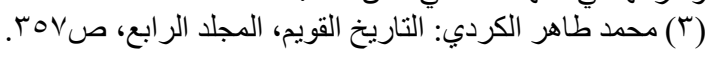

خامساً: تشكيل هيئة وطنية من أهالي جدة للتنقيب عن منابع للمياه: على الرغم من محاولات الأهالي وتكاتفهم في القيام

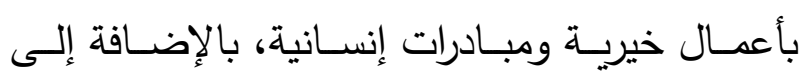
جهود ولاة الدولة العثمانية لإنهاء مشكلة نقص المياه

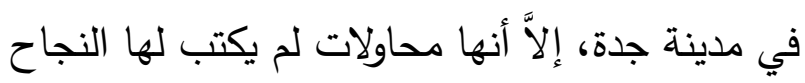

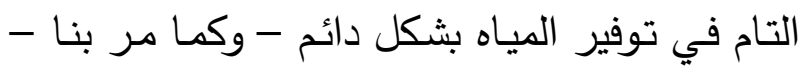
فقد كان يتوفر لفترات مؤقتة ثم يعود الوضع كما كان لـان

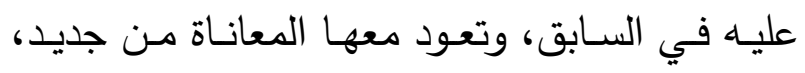
ولذلك اتفق الأهالي على القيام بعمل مشروع خيري

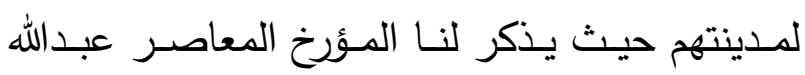
الغازي ذلك فيقول: "أن الأهالي قاموا بتشكيل هيئة تضم خيرة الأهالي تكون مهمتها البحث والتتقيب عن

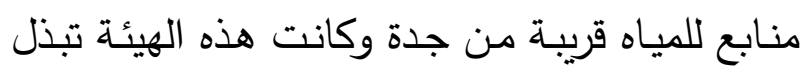

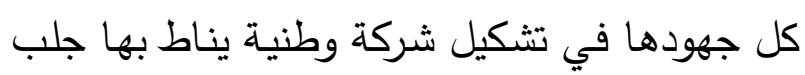

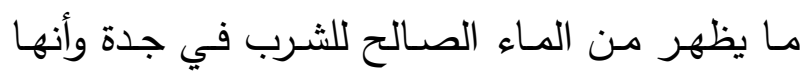
استحضرت مهندساً لهذه الغاية"(') وهذا دليل يؤكد أن الأهـالي كانوا يرغبون في لفئسي

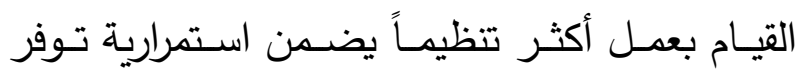

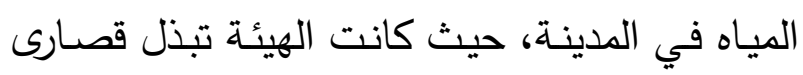

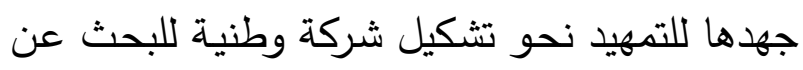
مصادر للمياه الصالحة للشرب، وأنها بدأت خطوتها الأولى بالاعتماد على متخصصين في هذا المجال

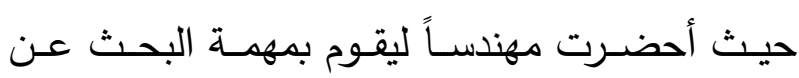
منابع للمياه قريبة من المدينة. 
العثــاني تعمل بشكل متقطـع (؟)، بحيـث لـم تـؤدي الغرض المنشود من جلبها أو الاستفادة التامة منها. وبـذلك ظلـت مشـكلة نقص الميـاه قائمسة، فلـم تتــهِ بترميم العيون أو بجلب آلات التقطير رغم محاولات الأهالي وحماسهم ومبادراتهم المستمرة وبذلهم كل ما

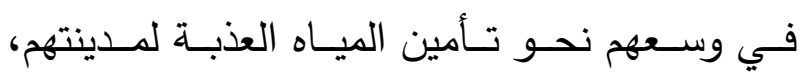
بالإضـافة إلى دعم ولاة الدولة العثمانيـة وحكام مكة المكرمة إلا أنها محاولات لم تنجح في القضاء على لـى

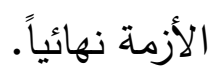

\section{نتائج الاراسة}

أبرزت الاراسة النتائج التالية: أن مبادرة التاجر فرج يسر في ترميم عين وادي قوز كانت مساهمة خالصـة منـه لتوفير المياه العذبة لمدينـة جـدة، حيـث لـم يلجـأ فـرج يسـر إلـى جمـع التبرعـات وأخذ الإعانـات مـن الأهـالي كمـا ذكـرت بعض الدراسات فقد ورد في الخطاب الذي رفعه فرج يسـر لترميم العين بأنـه أراد إعمـار عين جدة لكي ينتفـع بهـا المسـلمين والمســلمات وابتغــاء وجـهـ الله ولمنفعة عموم سكان وأهالي جدة"، دون الإشارة إلى قيامــه بجمـع تبرعـات مـن الأهـالي، ولـم يكـن معـــ شريك أو معاون في الترميم لإجراء مـاء العين إلى جدة.

تقدير ولاة الدولة العثانية وحكام الحجاز لجهود تجار جدة وأعيانها ممن كانت لهم مبادرات إنسانية ومساهمات خيرية لخدمة مدينة جدة وساكنيها، حيث

(7) عبد القدوس الأنصاري: تاريخ العين العزيزية بجدة، ص9 ؛.
وتقدير المصروفات اللازمة (1)، واتبعها برسالة أخرى

يطلب تسوية الأموال التي تحتاجها العين للترميم(؟). ولم تكثف لنا الوثائق والمصادر المعاصرة بعد ذلك عن أمر الهيئة وتشكيل الشركة الوطنية، كما أنها لم تكثـف لنـا عـن مـا تـم مـن تقـدير للمصـروفات والاحتياجـات الماليـة التي طلبهـا الحسين بـن علي لإصـلاح العين، إلا أن الدولـة العثمانيـة أرسلت في ذلك العـام مكائن تقطير جديدة بـدلاً عـن المكـائن المتعطلـة (r)، كمـا قامـت بلديـة جـدة بمحاولـة ترميم العين وإيصال مياهها إلى المدينـة في العام التالي (ء) لكنها كانت تجود بالمـاء ثم ينقطع مـرة أخرى، أمـا مكـائن التقطيـر فقـــ تعرضــت للخـراب بعـد عـامين وظلت تعمل بعد ذلك بشكل متقطع ثم قامت الإدارة الصـحية في الحجـاز بـدعم مدينـة جدة بشـراء آلـة تقطير جديدة بطاقة تنتج مائة طن عن طريق قرض حصـلت عليـهـ مـن مجلـس صـحة اسـطنبول عـام

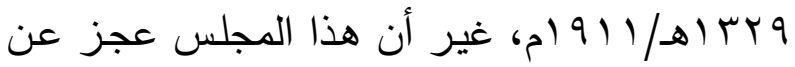
سداد ثمن الآلمة نظراً لعجز ميزانيته، فأعطاه مجلس صـحة اسـنبول قرضـاً تم سـاده في ظـرف ثـلاث سـنوات مـن رسـم التدابير الصـحية في الحجـاز (•)، وظلت آلة التقطير على وضعها السـابق طوال العهد

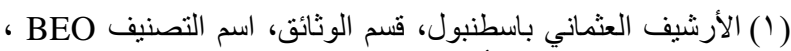

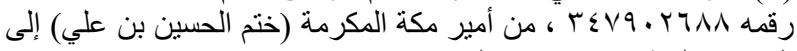

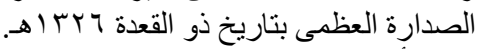

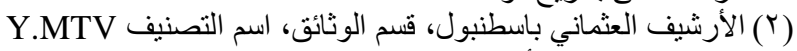

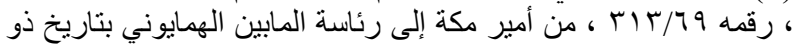

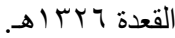

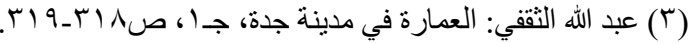

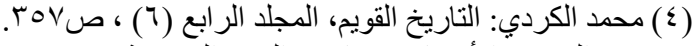

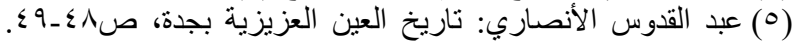

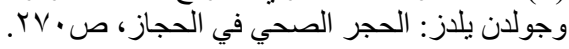


يعني أن مدينـة جدة كانـت في حالـة اتسـاع وتمـدد وزيادة في عدد السكان والوافدين إليها. واصل أهالي جدة جهودهم لتوفير المياه العذبة بطريقـة أكثر تتظيمـاً وأفضـل أعداداً فقـاموا بتشكيل هيئة من خيرة الأهـالي تمهيداً لإنشـاء شركة وطنيـة تكون مهمتها البحث والتتقيـب عن مصـادر أخرى للمياه قريبة من جدة كما استقدموا مهندساً متخصصاً لهذا الغرض، وذلك بعد استمرار نقص المياه وازدياد معاناتهم وتضررهم من جراء ذلك. تراجـع الدولـة العثمانيـة فـي السـنوات الأخيـرة لحكمها على الحجاز عن ترميم عيون المياه وعمل الصـيانة والمتابعـة اللازمـة لهـا وتوجهها نحـو جلب آلات التقطير لتحلية مياه البحر فكلما تعطلت واحدة جلبت الدولة أخرى وهكذا، ويبدوا أن ذلك عائد إلى الى التكلفة التي يحتاجها الترميم وصعوبة أعمال الصيانة والمتابعة والفترة الزمنية التي يستغرقها، مع الأخذ في الاعتبار عدم نقاء مياه العيون في الغالب وسـرعة تعرضـها للتلـوث، وفي المقابـل فـان آلـة التحليـة لا لاهي يستغرق نصبها سوى أيام قلائل، كما أن مائها أكثر

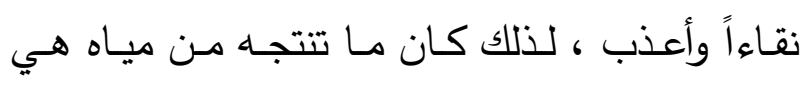
الخيـار الأفضـل لغالبيـة السـكان خاصــة القنصـليات

هيـأت آلـة التقطيـر "الكنداسـة" لمدينــة جـدة، الدخول في ركب المدنية الحديثة والتطور ، بالابتعاد عـن الطـرق التقليديـة للحصـول على الميـاه العذبـة

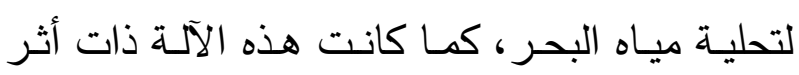

كـان يــتم الرفـع بأســماء المســاهمين لتقـوم الدولــة بتكــريمهم وتقليــدهم الأوســمة ومــنحهم الترقيـات، بالإضـافة إلـى مكافــهم بتسـهـيل إجـراءات أمسورهم التجاريـة عرفانـاً منهـا بفضـلهم وجهـدهم وخدماتهم المباركة لمدينتهم وساكنيها . تميـز أهـالي جـدة بحــهم لمـدينتهم وحماسـهـم لخدمتها وخدمـة سـاكنيها ووقوفهم إلى جانب الدولـة العثمانية بتكاتفهم مع ولاتها وحكامها بالحجاز بجمع التبرعـات وبـذل الأمـوال والرفـع بهـا رسـمياً للدولــة العثمانيـة للتعجيل في البدء بمشـاريع ترميم العيون

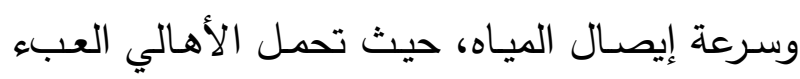
الأكبر في محاولة توفير المياه العذبة لمدينتهم. أن فكرة اسـتخدام آلـة التقطير أو جهاز تحليـة مياه البحر "الكنداسـة"، كانـت في البدء مبـادرة تقدم بها التاجر الجداوي "سـليم سلطان" وهذا دليـل يؤكد رغبــة الأهـالي فـي الاسـتفادة مـن التقنيـة الحديثـة وتطبيقها في مدينة جدة، أملاً في القضاء على نقص رله المياه العذبة ولتكون بديلاً عن ترميم ماء العين التي مدي تحتـاج إلى صـيانة مسـتمرة وتتوقف عـن الجريـان

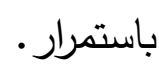

تزايد الطلب على كميات أكبر من المياه التي تحتاجها مدينـة جدة عامـاً تلو الآخر مثال ذلك في عام V ا I اهـ/199 (م كانت المطالب توفير خمسون

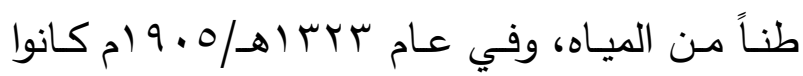

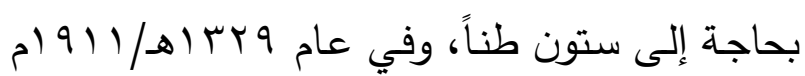
تم جلب آلة تقطير تُتجج مائة طن من المياه، وهذا 
إن اكتثـاف أحسواض الميـاه فـي منطقــة جـدة التاريخية يدل على جودة البناء وقوته في تلك الفترة

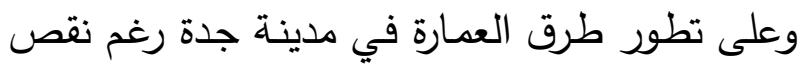
الإمكانيات المتاحة آنذالك من جميع النواحي ويبقى هذا الاكتثاف شاهد حي على كفاح الأوائل وصبرهم وتفانيهم في خدمـة مدينتهم وعلى بـراعتهم في أداء أعمالهم بكل دقة وأمانة وإخلاص.

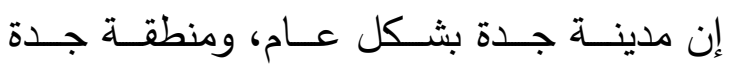
التاريخيـة بشـل خـاص، مـا تزال بحاجـة إلى جهـ

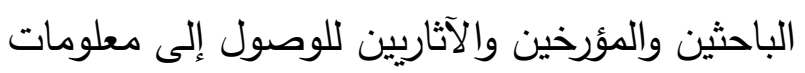

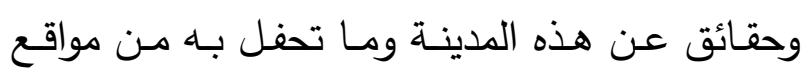
أثرية ومعالم عمرانية قديمة لم يتم الكثف عنها.

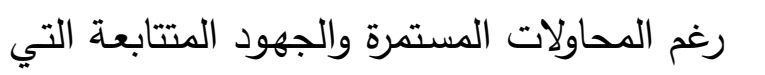
بُذلت من قبل الأهالي والولاة والحكام لتوفير المياه

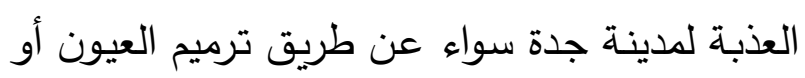

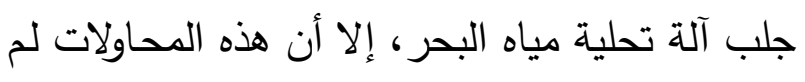

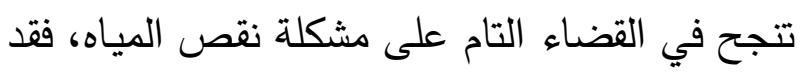
ظلت هذه المشكلة قائمة طوال السنوات اللاحقة.
اقتصادي واجتماعي حيث هيأت لأهالي جدة وظائف

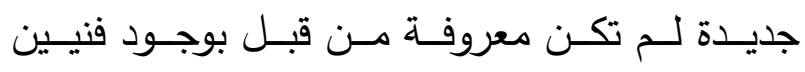
متخصصين لصيانتها وعمال للإشراف عليها وتجار لتوفير ما يحتاجه تشغيلها واستيراده من الخارج، كما

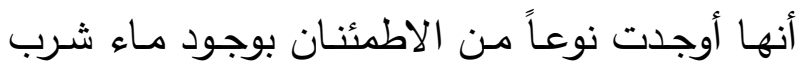
صافي نقي خاصة المستشفيات والقنصليات الأجنبية التي كانت تحرص على استخدامه.

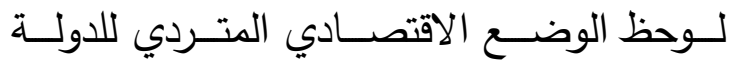
العثانية التي عجزت عن القضاء التام على مشكلة

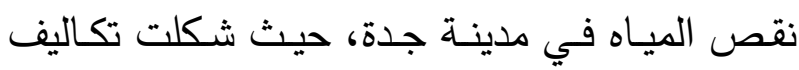
إجراء العيون وترميمهاً وجلب أعداد كافية من آلات

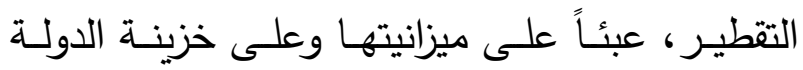
آنذاك، ففي كثير من الأحيان كانت مشاريع توفير

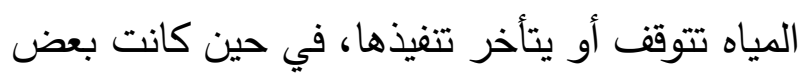

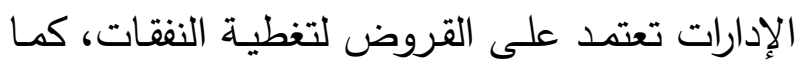

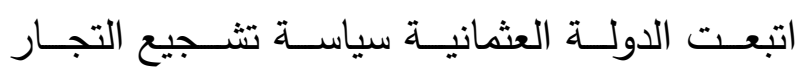
والأعيـان على التبـرع ليتحملـوا عنهـا عبـ لتبه تـوفير المياه إلى مدينتهم وذلك بقيامها بتكريمهم وتسهيل إجراءات أعمالهم التجارية. 
ملحق رقم (1)

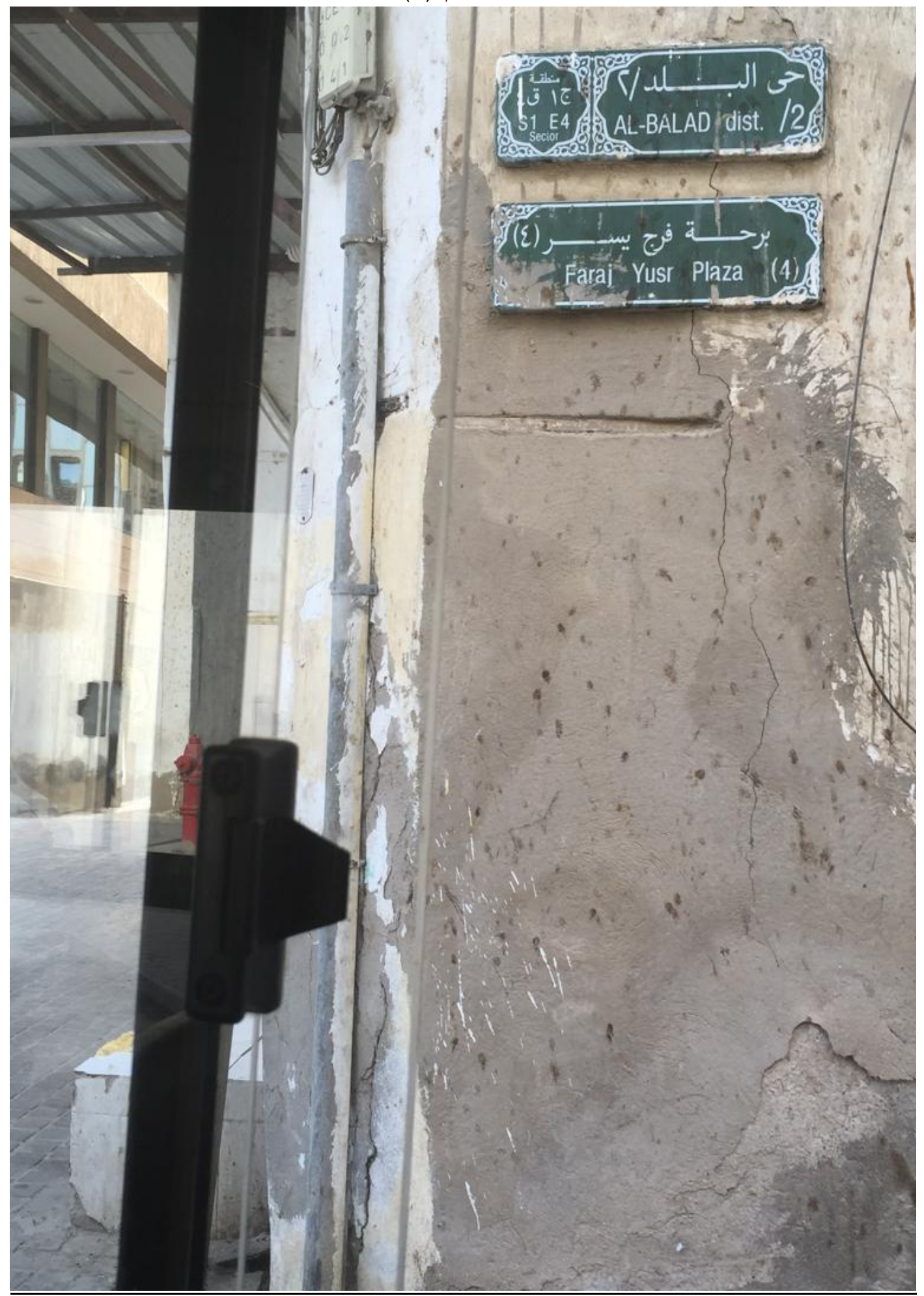

برحة فزّج يسر في منطقة البلد بجدة التاريخية 
دلال بنت محمد سليمان السعيد

$\varepsilon \wedge$

ملحق رقم(ץ)

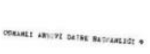

-....2_vu10<_005453_002_001.jpg
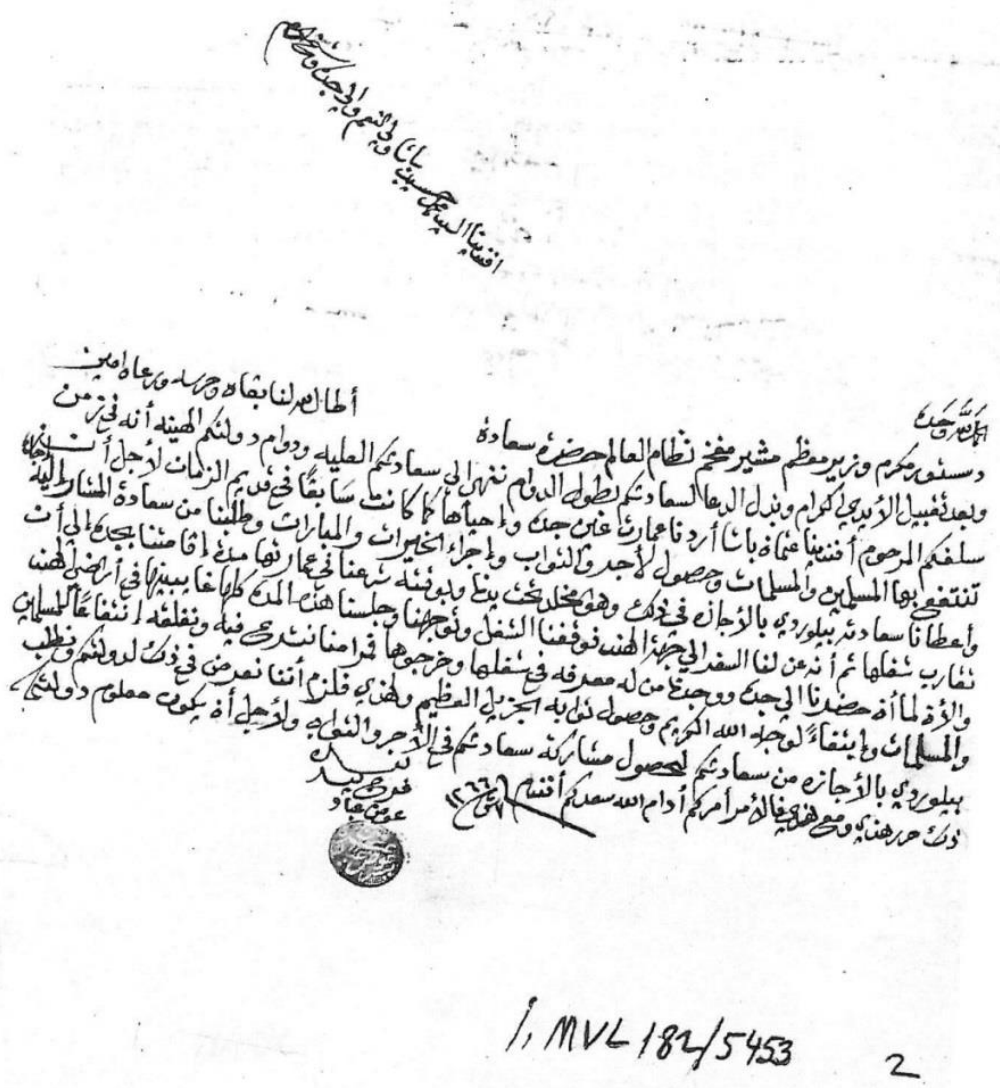

İ.MVL.00182

os://mail.google.com/mail///0/\#inbox/15ff9facbcf9333f?projector=1

-

$1 / 1$

خطاب بختم التاجر فرج يسر عوض عباد إلى والي جدة بطلب السماح بترميم مجاري عين الرغامة. 
ملحق رقم (ץ)

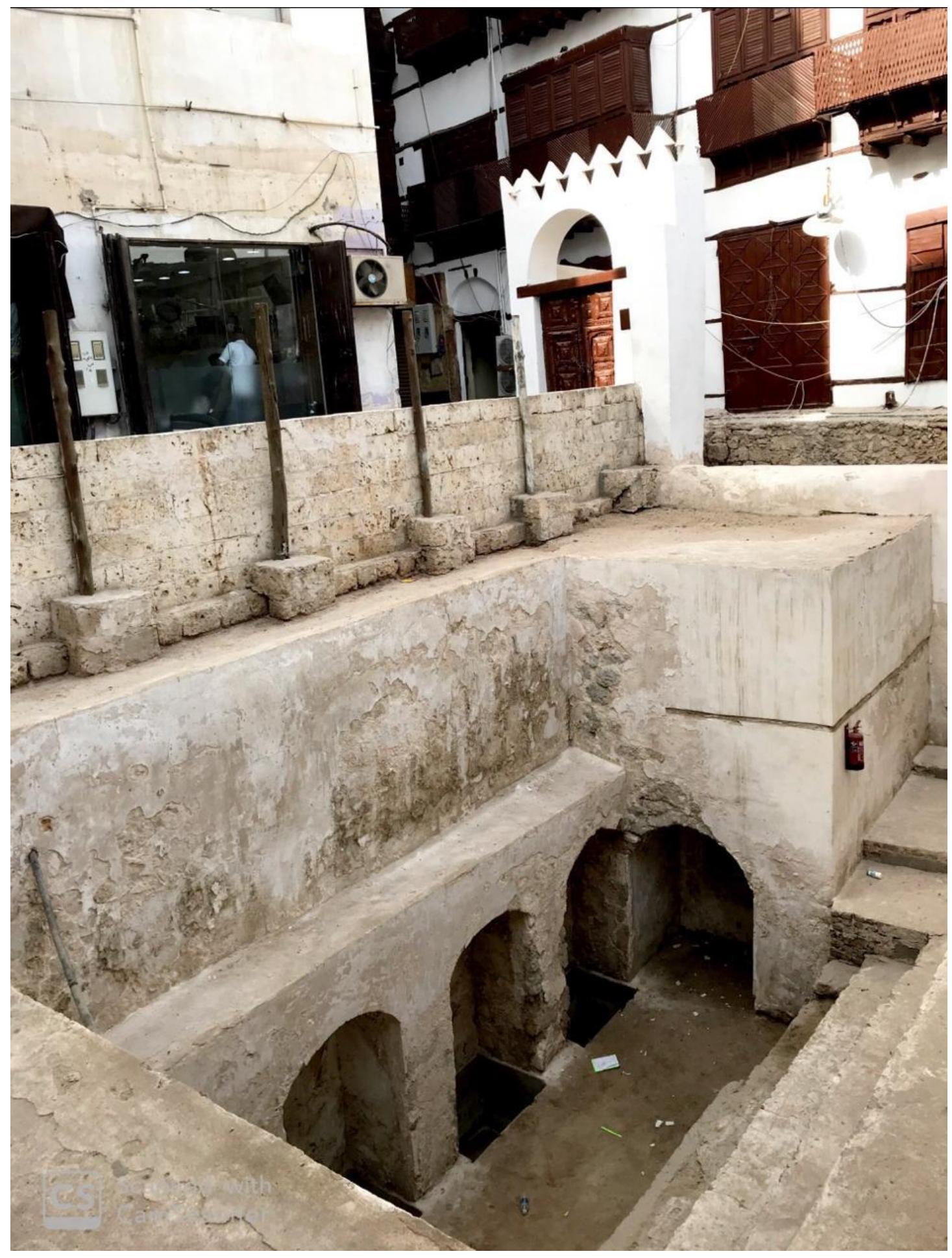

صورة لأحواض عين فرج يسر التي تم اكتشافها في سوق العلوي في منطقة جدة التاريخية 


\section{ملحق رقم (£)}

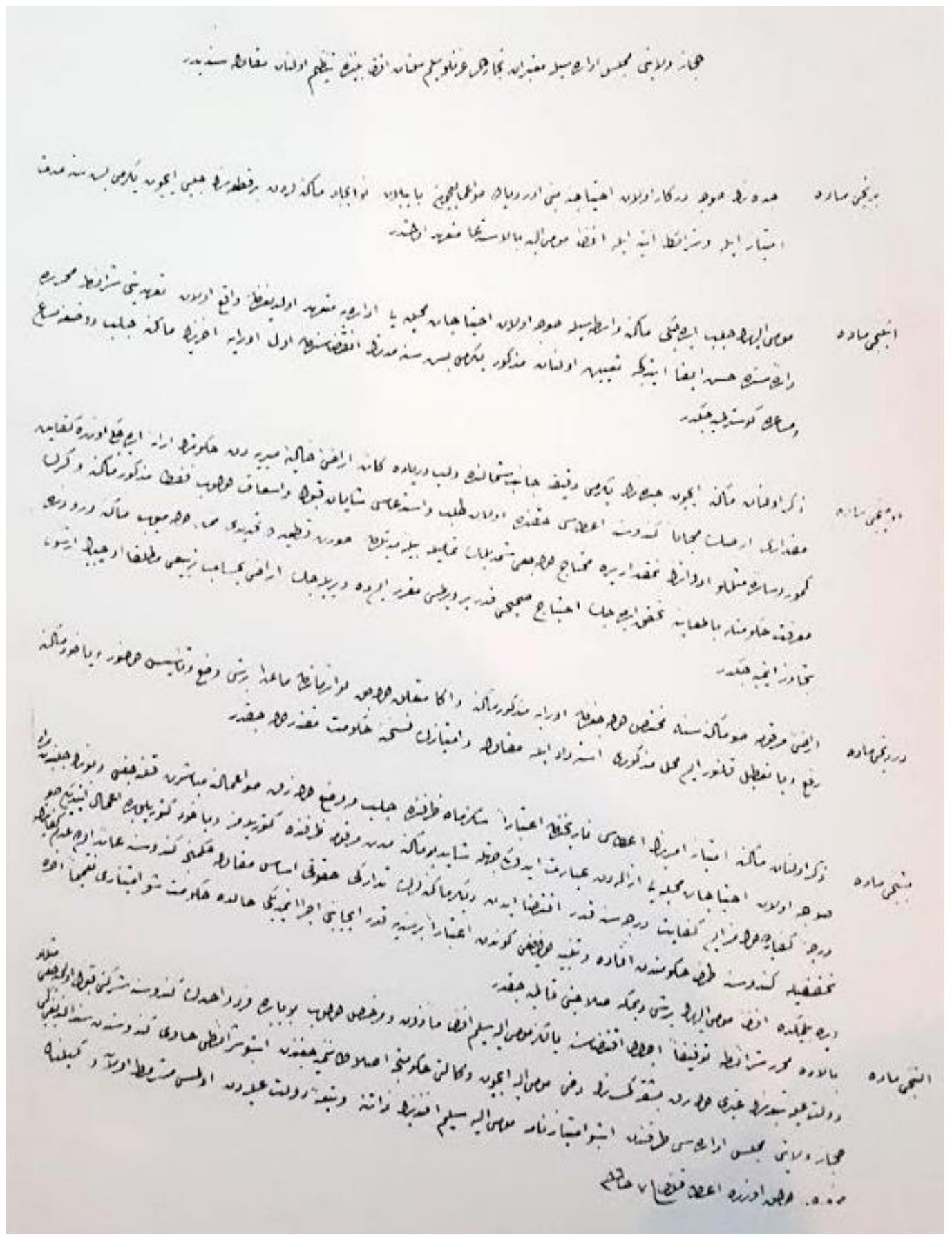

العقد المبرم بين مجلس إدارة ولاية الحجاز والتاجر سليم سلطان لشراء جهاز تحلية مياه البحر بتاريخ (ه 


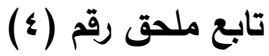

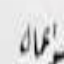

$\checkmark i$

(j) N W

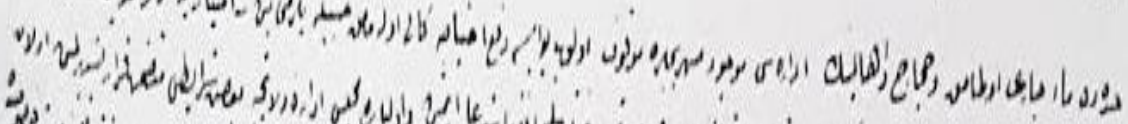

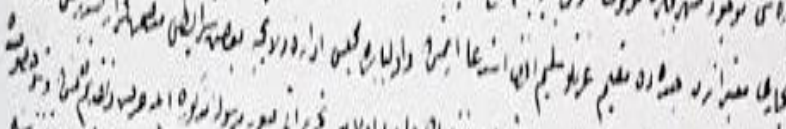

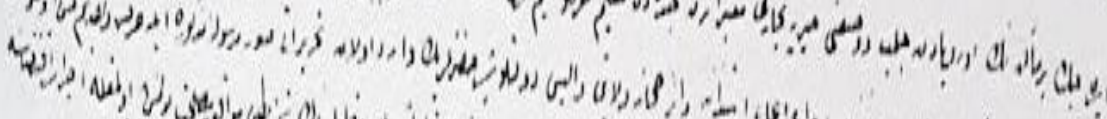

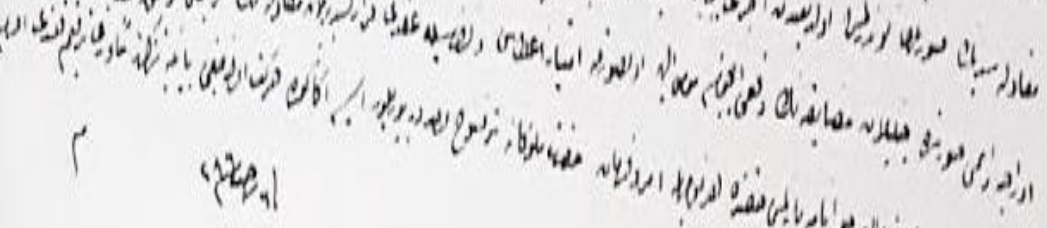
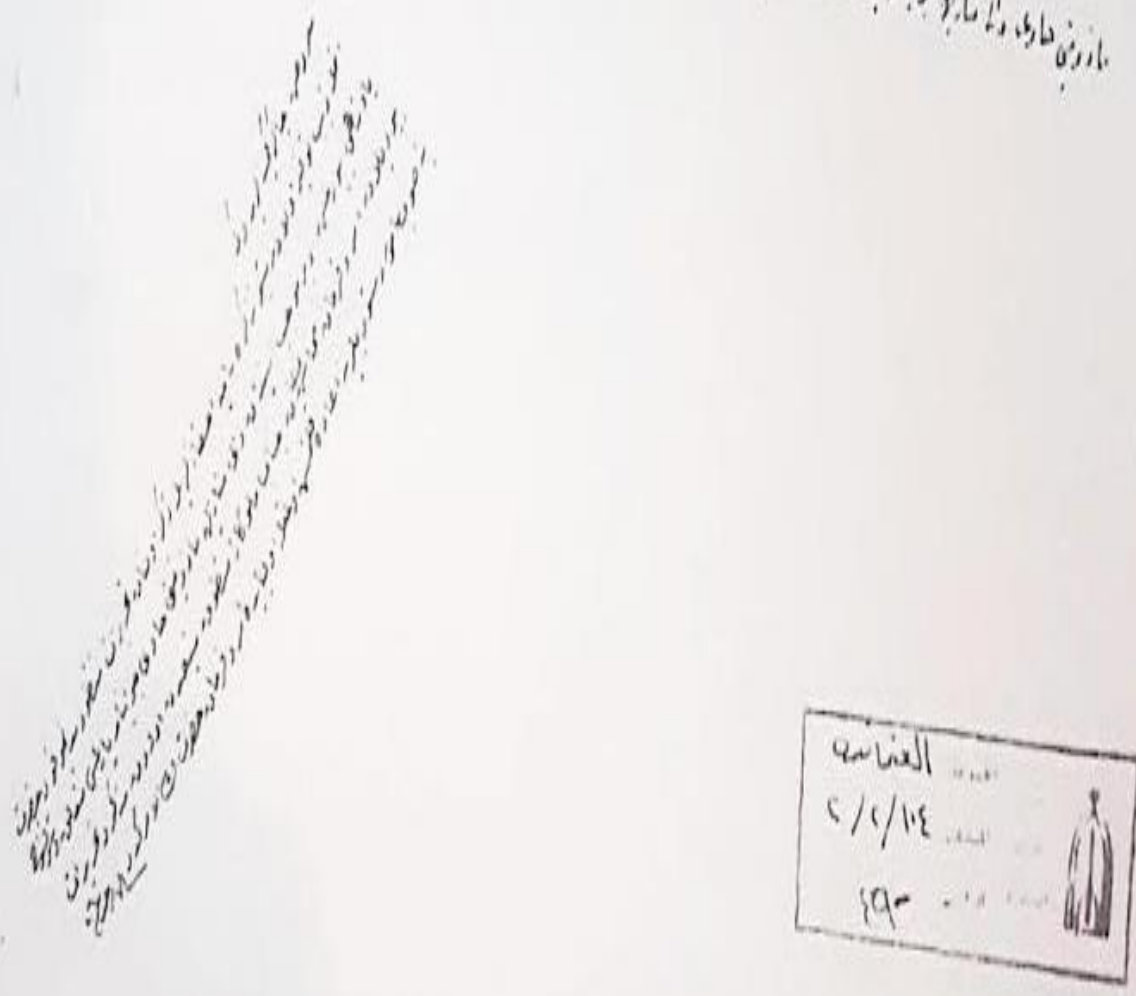

مضمون الوثيقة: تضمنت الوثيقة معلومات عن موقع آلة تحلية مياه البحر في الثمال مساحتها ثلاثة آلاف

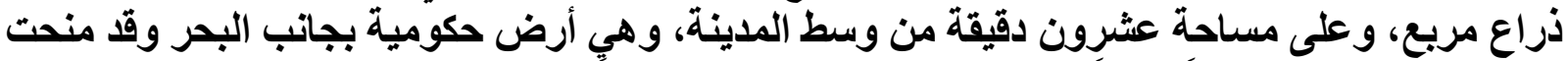

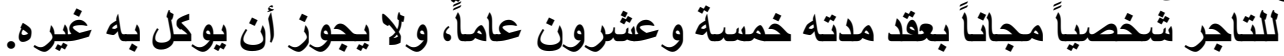




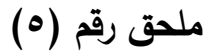

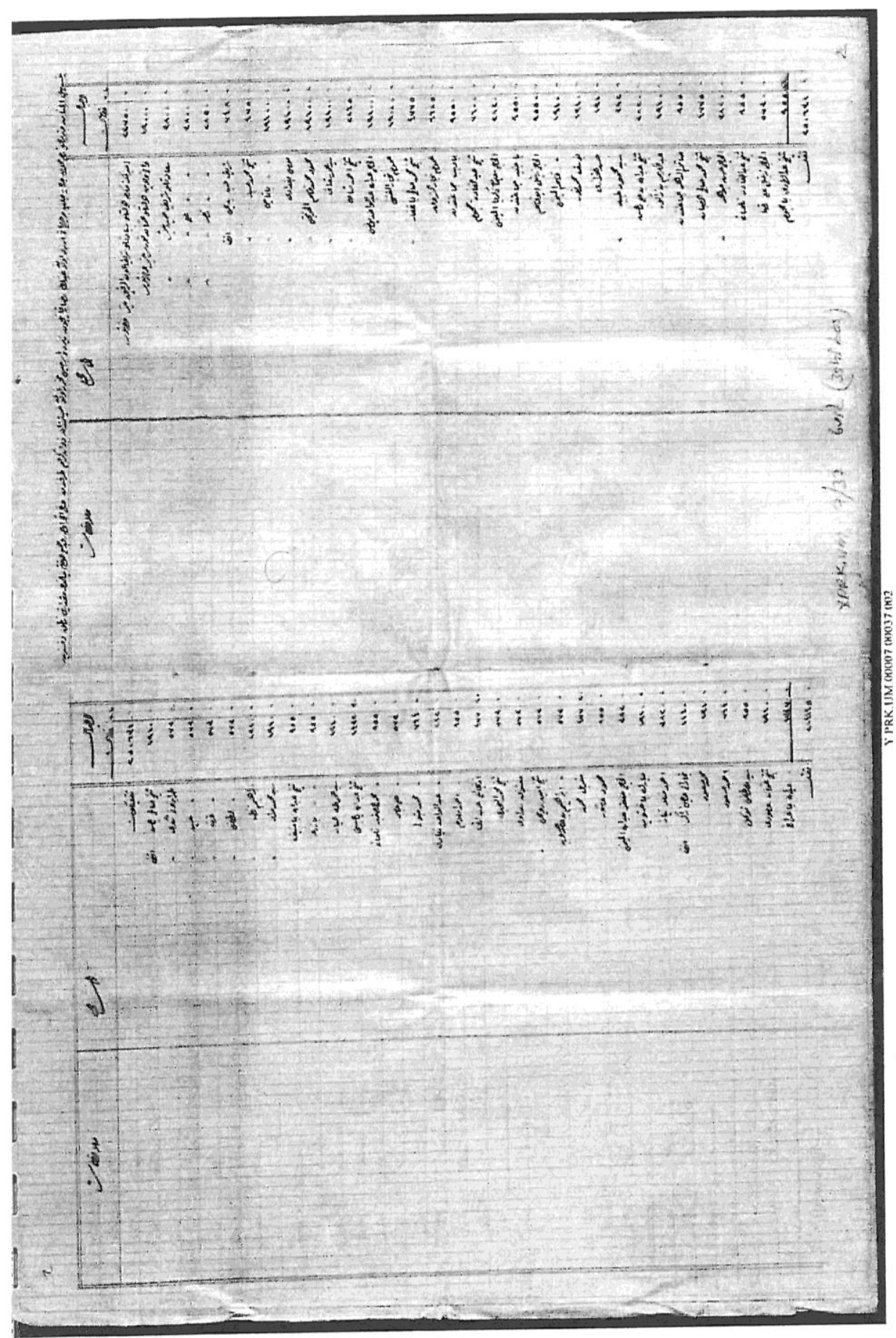

قائمة بأسماء المتبرعين من الأهالي من أصحاب الثروة لجلب المياه لجدة ومقدار الأموال التي دفعها كل

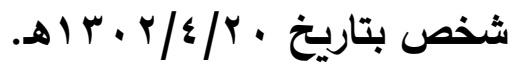




\section{تابع ملحق رقم (•)}

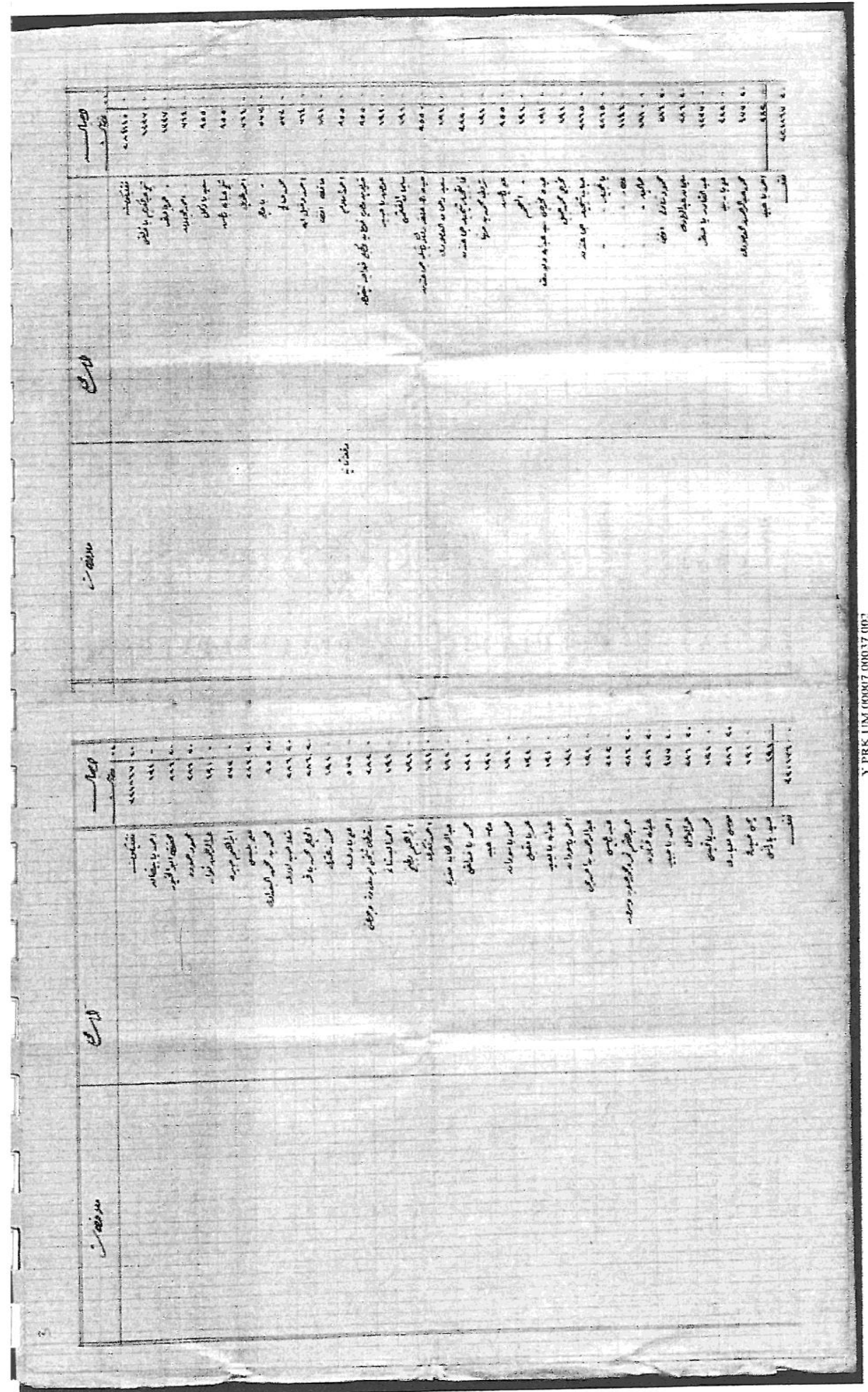


دلال بنت محمد سليمان السعيد

تابع ملدق رقم (0)

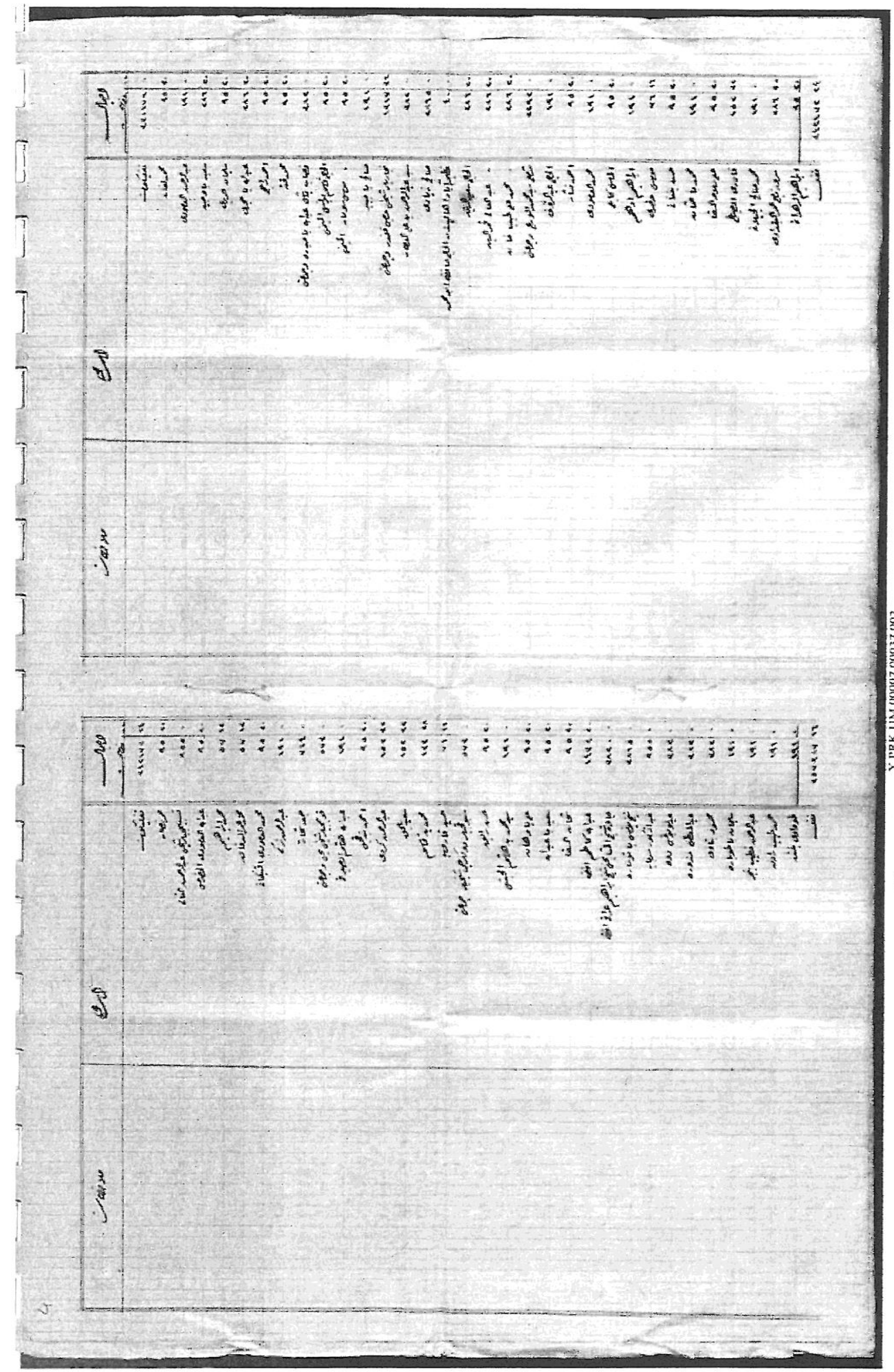




\section{تابع ملحق رقم (•)}

قائمة بأسماء المتبرعين من أهالي جدة ومقدار الأموال التي دفعها كل شخص

\section{(بعد ترجمتها إلى اللغة العربية)}

\section{كثف يوضح المبالغ التي دفعها أصحاب الحمية من أجل مد العين المرغوب في مدها من الوزيرية إلى جدة}

\begin{tabular}{|c|c|c|c|c|c|}
\hline المبلغ & الاسم & المبلغ & الاسم & المبلغ & الاسم \\
\hline ITHV & الشيخ عبد الكريم باخدلقى & 191. & الشيخ صلالح باعشن & TMVO. & الثريف عون الرفيق باثـا \\
\hline ITHV & الثيخ عمر باصقر & OVT & شكري الطربزوني أفندي & $19 \ldots$ & عثمان نوري باثنا الو الي \\
\hline$V\urcorner \varepsilon$ & الشيخ أحمد عجلان & OVT & حسين الطربزوني أفندي & $r \wedge \ldots$ & الثريف حسين باشنا \\
\hline 900 & سعيد بادكل & OVT & عزت الطربزوني أفندي & rی.. & الشريف على باشـا \\
\hline 900 & الشيخ عبد الله باعشن & OVT & لطفى الطربزوني أفندي & rAO. & الثريف ناصر باشـا \\
\hline VI & أحمد الطويل & 191. & إبر اهيم ناظر أفندي & $V \leqslant \Lambda$ & الشريف حسين بن يحيي \\
\hline OVT & أحمد با حاج & 191. & سبد محمد مر اد أفندي & $191 \ldots$ & الشيخ محمد حسين أفندي \\
\hline OVT & محمد صالح & 900 & الشيخ عبد الله با منيف & $191 \ldots$ & الثيخ محمد باناجه أفندي \\
\hline VI & أحمد دخيل الله & 900 & الشيخ عبد الله بازر عه & $191 \ldots$ & موسى البغدادي \\
\hline 191 & حافظ أفندي & 191. & السيد عمر طه البار & $191 \ldots$ & محمود محمد قاسم الخونجي \\
\hline 900 & أحمد إسلام & $T \leqslant r r$ & الثيخ عبد الله باعيسى & $191 \ldots$ & السيد عمر السقاف \\
\hline 900 & الخديوية نيقوصه وكيل الثركة & 900 & الشيخ محمد التلمساني & r^TO & الثيخ أحمد مشاط \\
\hline 191 & عوض باجبر ع & OVT & الثيخ على الجاسر & $191 \ldots$ & يونس الحاج عبد الله عبدالواحد \\
\hline 191 & سليمان القتمي & $V T \Sigma$ & محمد المتبولى & $191 \ldots$ & عموم تجار الفنن \\
\hline 900. & من جماعة دلالين حلقة جدة & rAT & عبد الو احد الزيادي & $\varepsilon \vee \vee 0$ & الثيخ محمد صالح باغفار \\
\hline 191 & سعبد دحمان العامودي & 900 & الشيخ أحمد إسلام " & 7710 & عموم تجار الشروق \\
\hline rAT. & من جماعة المجدفين & $\varepsilon V V$ & حسن أغا الأرزنجاني & 900. & من جماعة با ديب \\
\hline 191 & الشريف محمد بن مهنا & OVT & الثيخ محمد البحيري & $V 7 \ldots$ & الثيخ عبد القادر جمجوم \\
\hline 900 & على باعشن & OVT & معتوق السعدو اى . & rAr. & الحاج سليمان زكريا الميمن \\
\hline 191 & على العجم & OVT & الشيخ محمد الرويحي & 900. & من جماعة با جنيد \\
\hline 191 & جدة السيد عبد الله ويوسف مخرج & OVT & إبر اهيم بن حامد حسوبة & 900 . & الحاج زينل أبو قاسم \\
\hline 191 & المخرج محمد جميل & $\sum V V$ & محمد المغربل & 191. & الحاج قاسم الميمني \\
\hline rАT० & من جماعة شيخ الحباب & 900 & محمود عاشور & 191. & يوسف محمد نور \\
\hline r190 & من جماعة عمال الزيت & TAY & جعفر عبد الله الميمني & 191 & حسن هز ازي \\
\hline $11 \leqslant 7$ & من جماعة العطارين & 191. & مبارك با خشوين & rAT & السيد محمود طيلية \\
\hline 191. & من جماعة الحمالين & rAT. & أحمد منلا نياز & rNY. & الشيخ عبد الله بن على باعشن \\
\hline 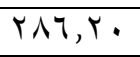 & محمود الشازلي أفندي & $11 \leq$. & الحاجزاكر البخارى & 191. & عبد الكريم بن زاكور \\
\hline 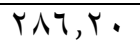 & سليمان عبد الهادي & 191 & محمد مسعود & 900 & من جماعة صائم الدهر \\
\hline ITHV & عبد القادر باصقر & VI & أحمد مسعود & $\sum V \vee O$ & الثيخ محمد صـالح الصبان \\
\hline rAT & على باربيد & 900 & سيد مصطفى توكيل & rAT. & الحاج حسن جوهر \\
\hline$\varepsilon V V$ & محمد عبد الرحمن العامودي & 191. & الشيخ عثمان العامودي & 900 & الثيخ عبد القادر التلمساني \\
\hline rAY & أحمد با عبيد & ITHV & الشيخ عبد الله باعر اقي & OVT. & الحاج زينل على رضا \\
\hline $90, r$. & عمر نصار & 90 & محمد لفان & 900 & الشيخ عبد الهادي باجمجوم \\
\hline 900 & المسبح الرحمن الغالي شيخ عمال & 191 & عبد الرحمن العامودي & 191 & أحمد بابيضان \\
\hline
\end{tabular}




\begin{tabular}{|c|c|c|c|c|c|}
\hline المبلغ & الاسم & المبلغ & الاسم & المبلغ & الاسم \\
\hline $90, r$ & عبد الله العامودي الحضرمي & rAT & سعيد با وجيه & rAT & محفوظ أبو الخيور \\
\hline$O V, I r$ & محمد إبر اهيم & 90 & سليمان الحريري & Y^T & محمود حمودة \\
\hline$O V, I T$ & محمد عمر الدقاق & rAT & عبد الله باحجري & 191 & عبد الرحمن نورار \\
\hline $90, r$. & محمد العامودي التنبكاتي & 90 & أحمد راجح & ovr & إبر اهيم جبرة \\
\hline 191 & عبد الرحمن تركي & 90 & محمد فتة & Y^T & على بلبس \\
\hline Vาร & جمعة شحاتة & rAT & عبد الله با حيدري وجماعته & 90 & محمد بن محمد البغدادي \\
\hline OVT & وجيمي شتيخ عمال الذهب & 90 & الحاج قاسم يونس الميمني & Y^T & منلا حسين لادي \\
\hline 191 & عبد الله هاثم الصيرفي & 90 & الحاج موسى سومار المبمني & Y^T & الحاج محمد باقر \\
\hline $90, r$ & أحمد بندقجي & 191 & صالح با جبير & 191 & محمد الزعتري \\
\hline IOY,TY & عبد الرحمن الكردي & ITIV & وجماعته قلندر رئيس النجارين & OVT & على بادعدعي \\
\hline IOT,YY & سعبد بلحق & rAT & سبد عبد الرحمن بن على & TAT & من الثيخ يوسف وجماعته \\
\hline Ir, & محمد بن قاسم & ห^プ & صـالح الزيادي & 191 & أحمد البستاني \\
\hline$V 7,17$ & حسين قاروب & $\varepsilon$. & أهالى عظيم آباد أبو محمد من & 191 & إبر اهيم البطيخ \\
\hline OVT & شيخ عمال الزوارق وجماعته & rAT & الحاج سعبد الدين & 191 & أحمد فكري \\
\hline $90, r$. & حسن رايق & rAT & الحاج عبد العال قمر الدين & 191 & عبد الوهاب المغربي \\
\hline 191 & سبد محمد بن هاشم الحبشي & Y^T & الحاج محمد على طيب خان & 191 & محمد با خدلقي \\
\hline $90, r$. & على با و هان ع & TrQt & سيد محمد الورع وجماعته & 191 & حامد عبيد \\
\hline $90, r$. & سعيد با عبد الله & 191 & الحاج عبد الرؤوف & 191 & محمد با سودان \\
\hline $90, Y$. & شحات السقا & 90 & أحمد النشار & 191 & عمر بامقبل \\
\hline $1 \leq r, Y$, & عبد الله كاظم أفندي & 191 & محمد العامودي & 191 & عبد الله بـا بعير \\
\hline rAT. & شيخ مشايخ إبر اهيخ الثره اقي أفندي & 90 & ألماس الكابلي & 191 & أحمد با سودان \\
\hline 广ヘプ & الشيخ يونس با تومارة & 191 & إبر اهيم أدهم & 191 & عبد الرحمن بن أحمد بحي \\
\hline 900 & عبد الثكور باسربايه & VI & موسى الحضري & rAT & عنبر با عيسى \\
\hline TAT & عبد لو بوقس دوه & 90 & حسن البناني & 「^T & حسوبة وسرور هاشم نمر ومحمد \\
\hline TAT & عبد المعطى مندورة & 191 & محمد با عثمان & TAT & عبد الله قشلان \\
\hline rAr & محمود البتاوي & 90 & على سلامة السقا & $\varepsilon V V$ & أحمد با جبير \\
\hline 191 & سليمان باطوبارة & IOY, Tr & قادري الصباغ & Y^T & عمر الو عل \\
\hline 191 & عبد الرحمن خطيب بنجر & 191 & محمد صسالح الِيلاني & 191 & محمد با قيسي \\
\hline 191 & محمد طيب ر ادن & 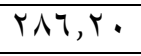 & سرور تابع عمر البغدادي & $r \wedge T$ & موسى الملبارى \\
\hline \multirow[t]{3}{*}{191} & طو اوى بنتن & $90, Y$ & إبر اهيم الز هر اني & 191 & يحيي الصبرفي \\
\hline & & & & 191 & حسين با رأس ع ع \\
\hline & & & & & rovqAV, المجموع I I \\
\hline
\end{tabular}




\section{ملحق رقم (؟)}

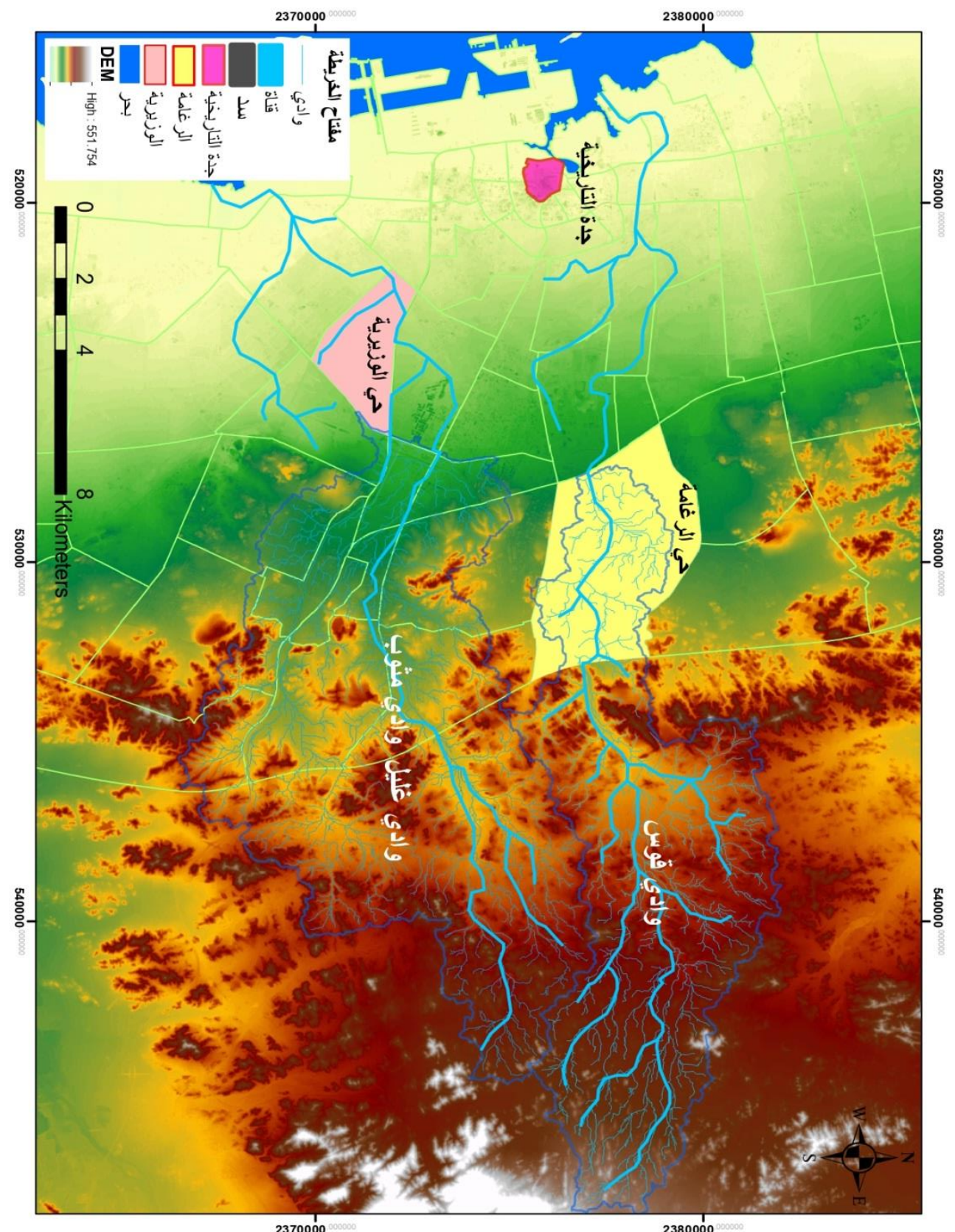

خريطة تصور الموقعان اللذان كانا يمدان جدة التاريخية بالمياه

(عين وادي قوز بالرغامة وعين الوزيرية)

المصدر : دكتور عبد الحميد جميل عضو هيئة التدريس بقسم الجغرافيا ونظم المعلومات الجغرافية بجامعة ولرعامين البهرئ الملك عبدالعزيز 


\section{تابع ملحق رقم (؟)}

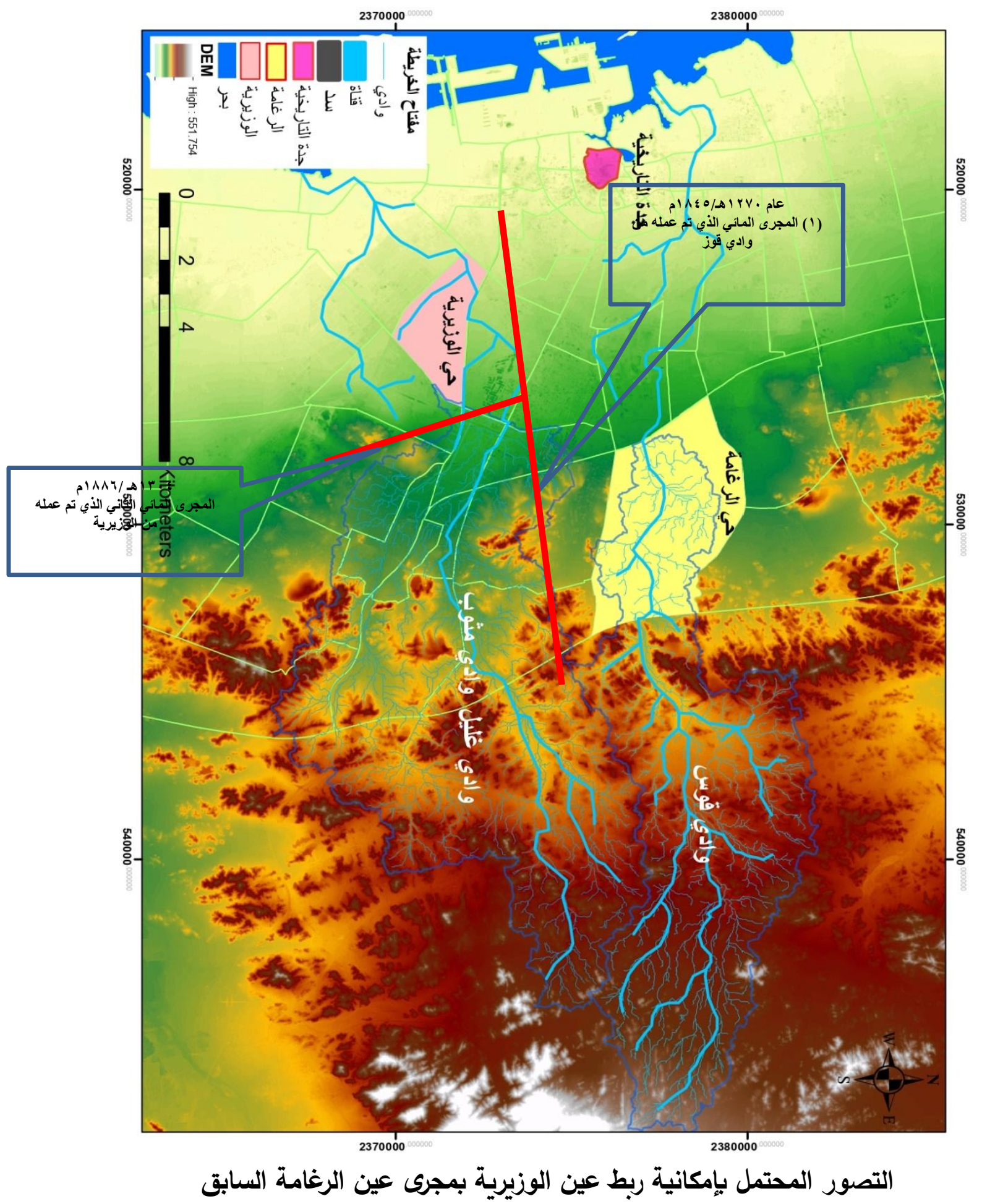




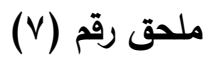
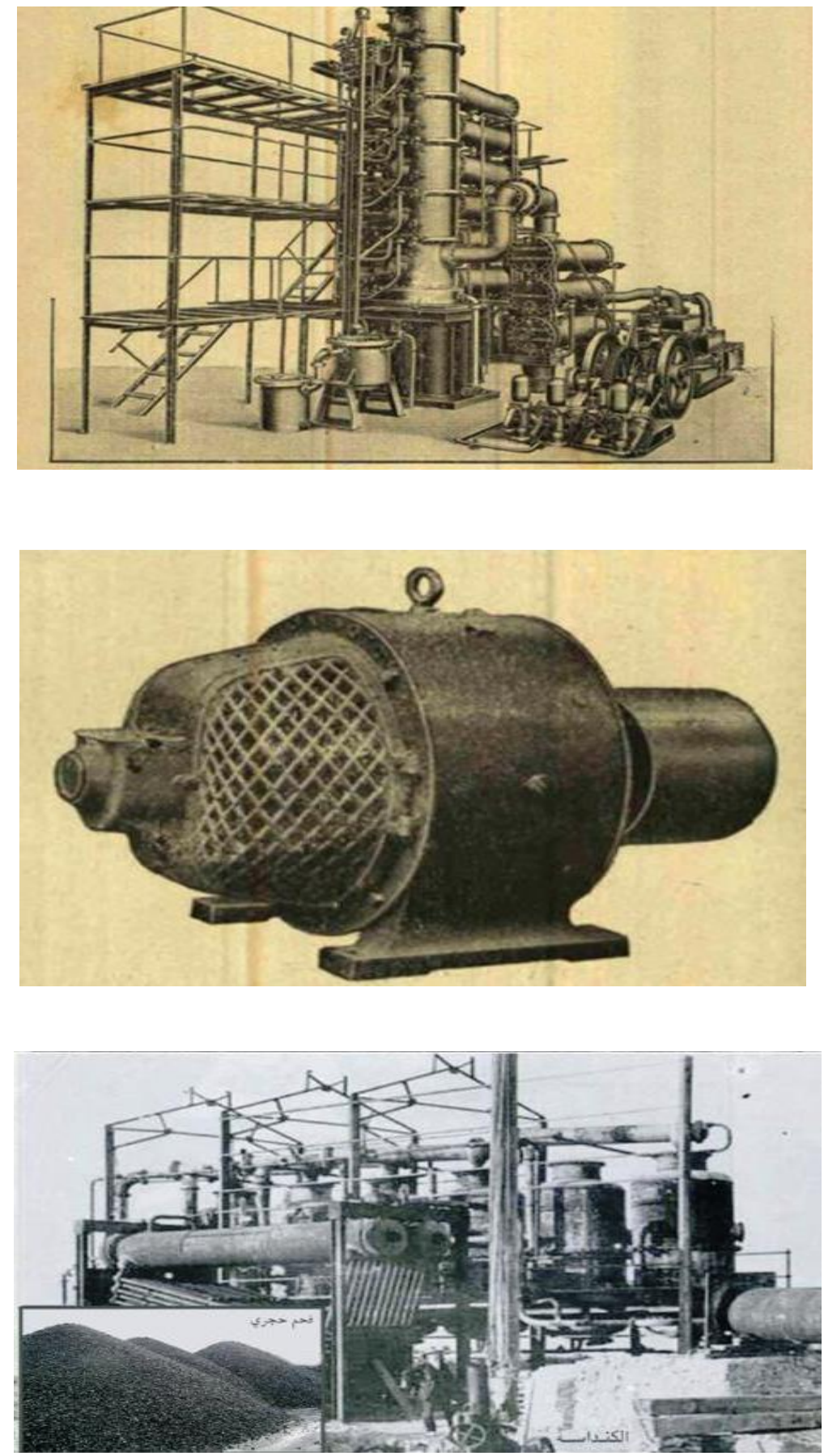

صورة للكنداسة وبعض الأجزاء التي تتكون منها

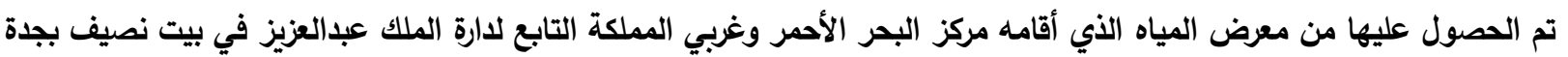

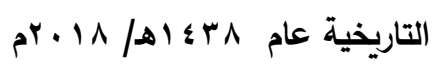




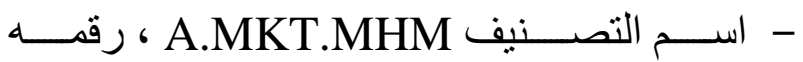

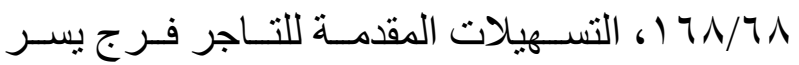

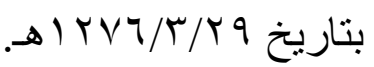

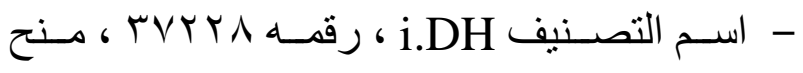

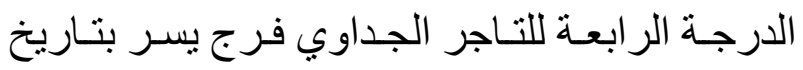
(

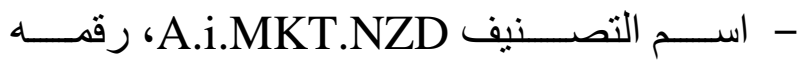

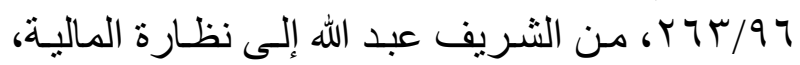
بدون تاريخ.

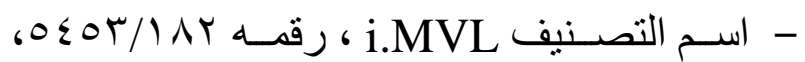

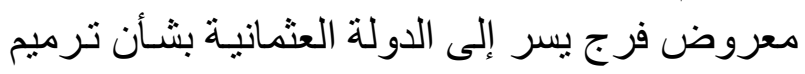

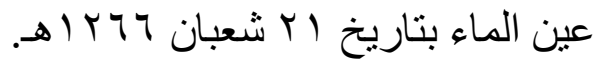

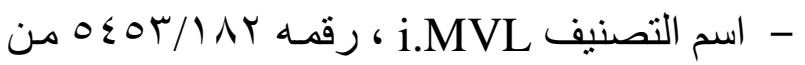

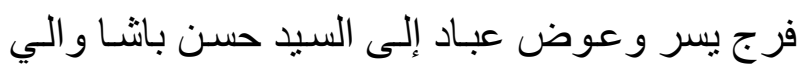

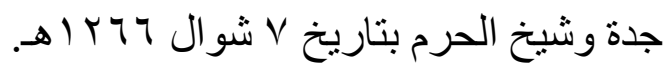

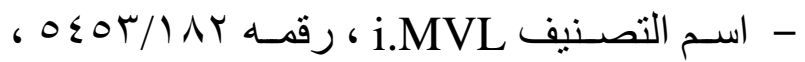

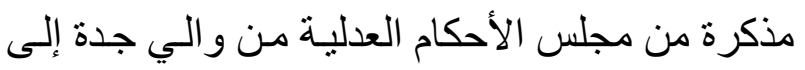

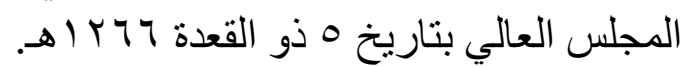

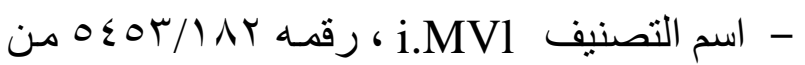

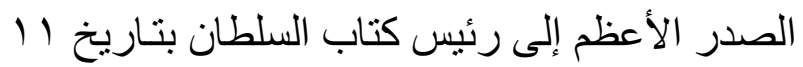

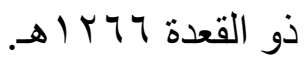

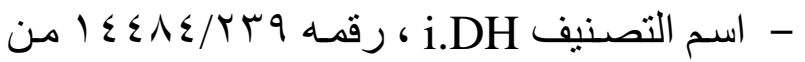

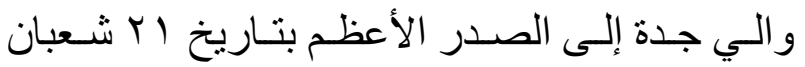
(I) I IT

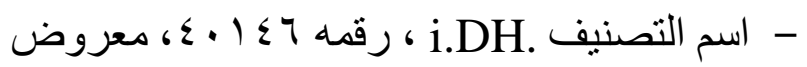
بعنوان ترميم قناة عين المياه الجارية إلى جدة بتهاريخ ( $1 / 10 / T / 19$

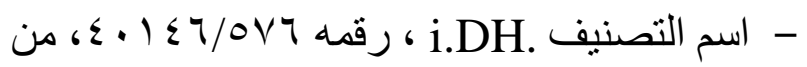

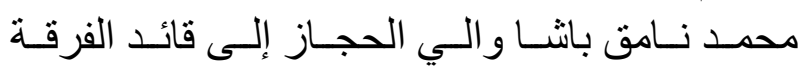

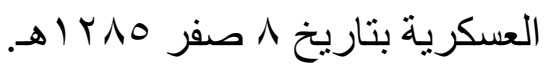

قائمة المصادر والمراجع

$$
\text { - وأولاً: الوثائقي: }
$$

أـ وثائق دارة الملك عبد العزيز ، مركز تـاريخ مكة المكرمة، قسم الوثائق العثمانية:

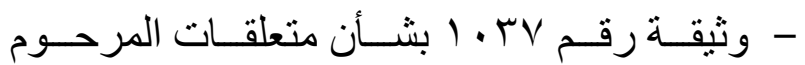

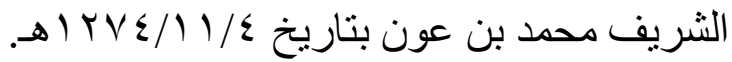

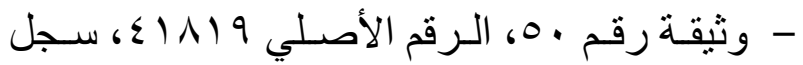

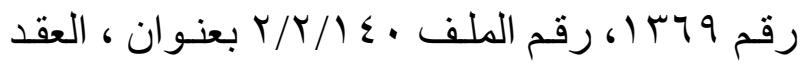

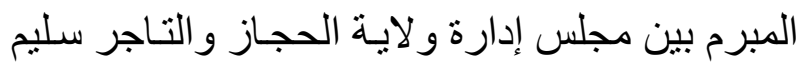

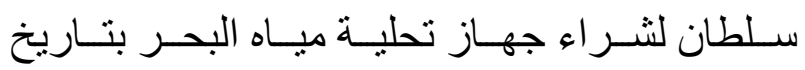

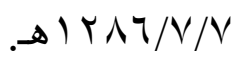

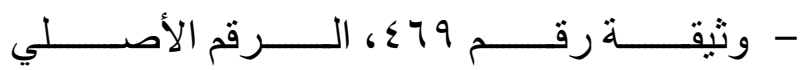

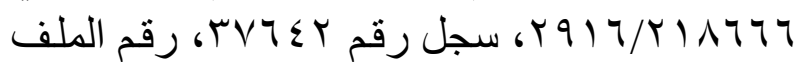

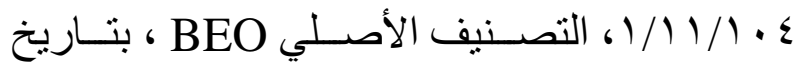
( بـ وثائق الأرشيف العثمانى بإسطنبول:

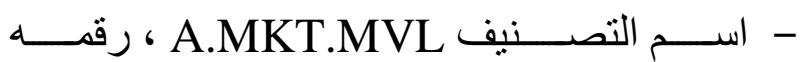

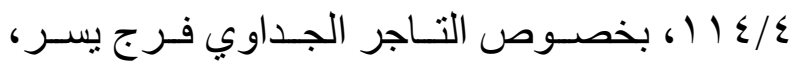

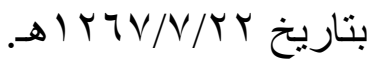

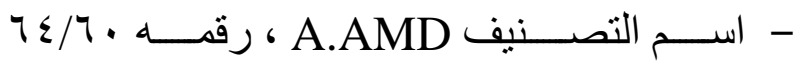
بخصوص تأدية الأموال التي أخذت من التاجر فرج رجاته

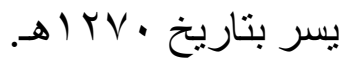

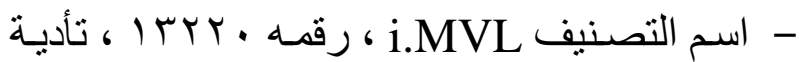

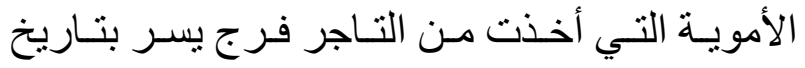
( )

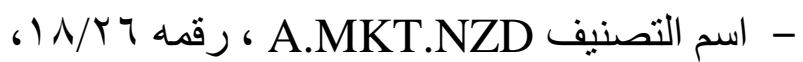

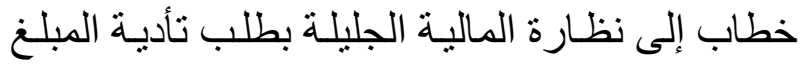

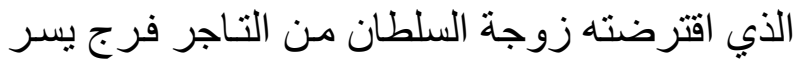

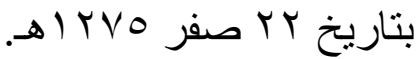




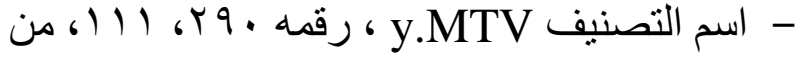

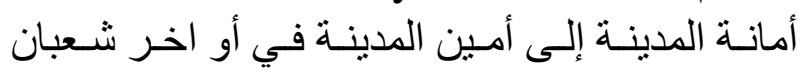

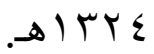

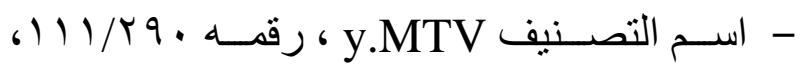
معروض مقدم إلى المنظور العالي في أواخر شـعبان

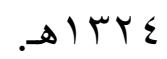

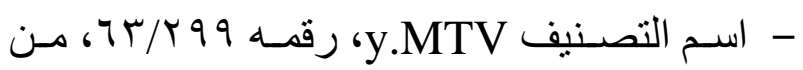

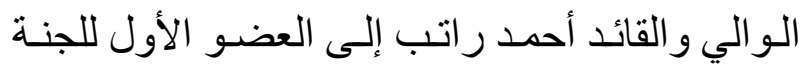

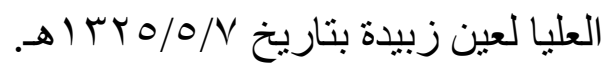

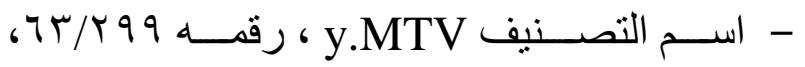

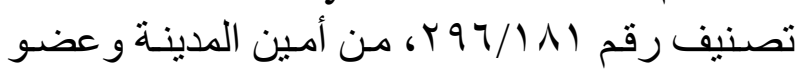

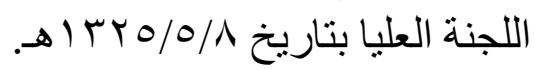

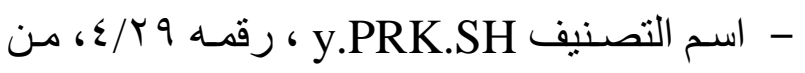

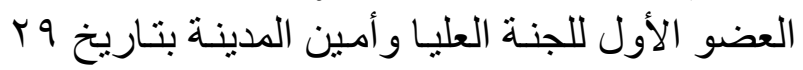
شعبان O مبر الهـ.

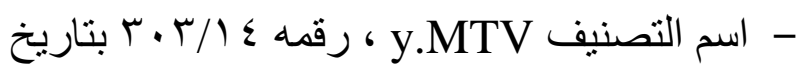

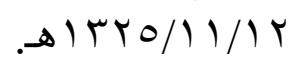

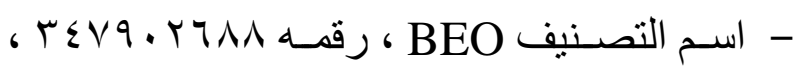

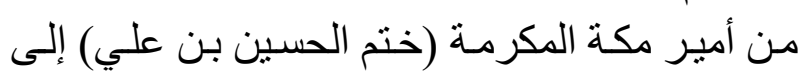
الصدارة العظمى من شهر ذو القعدة 7 ب أهـ.

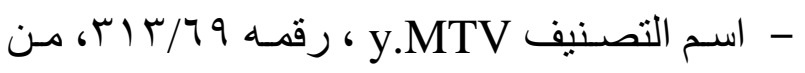

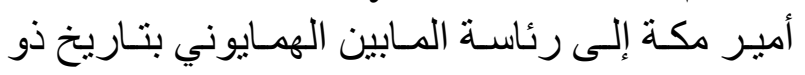

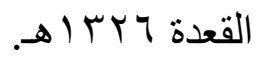

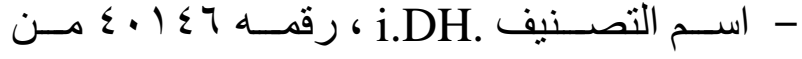
الصدر الأعظم إلى رئيس كتاب السلطنة بتاريخ 19

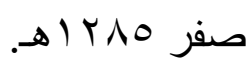

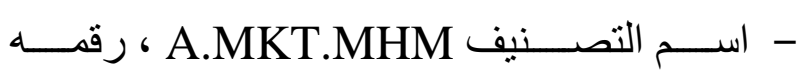
أهـ

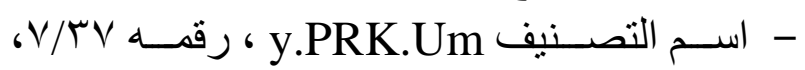

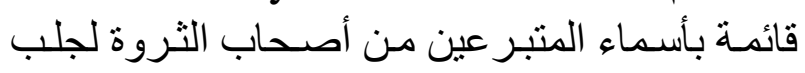

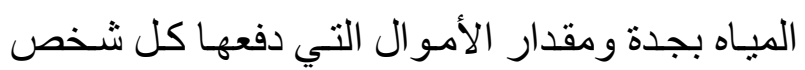

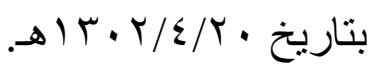

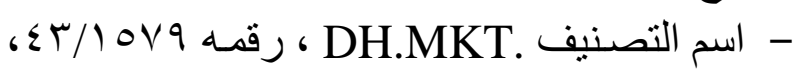
من و الي الحجاز إلى نظارة الداخلية الجليلة بتاريخ 9

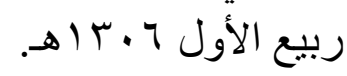

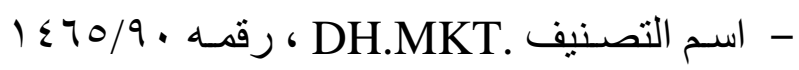

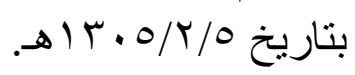

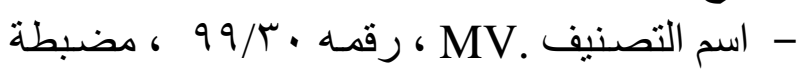

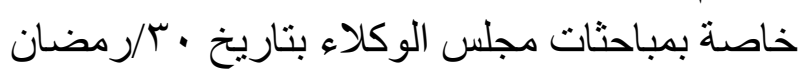

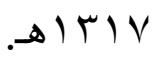

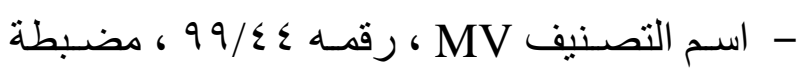
خاصة بمباحثات مجلس الوكلاء، بتاريخ آ ذو القعدة

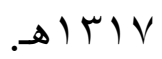

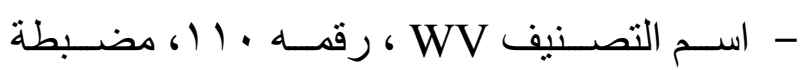

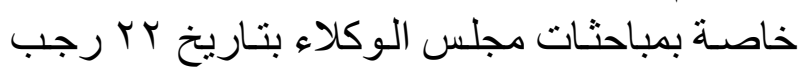

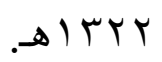

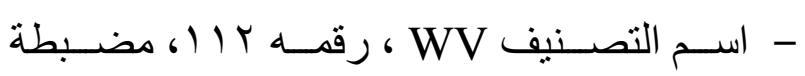

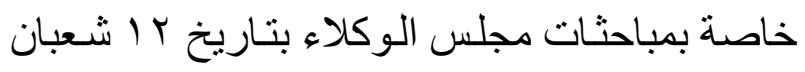

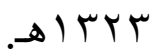




$$
\begin{aligned}
& \text { الشمسية، ب.ت ، الجزء الأول. } \\
& \text { •)باشا: أيوب صبري. } \\
& \text { مرآة جزيرة العرب. }
\end{aligned}
$$

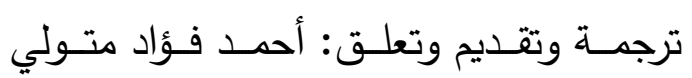

$$
\text { والصفصافي أحمد المرسي. }
$$

الطبعة الأولى. الرياض: دار الرياض للنشر

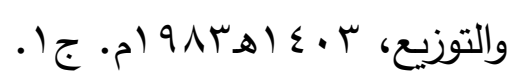$$
\text { ؟) باطرفي: خالـد }
$$$$
\text { جدة، أم الرخاء والثدة. }
$$$$
\text { V البتنوني: محمد لبيب. }
$$

الرحلـة الحجازيـة لـولي الـنعم الحـاج عبـاس

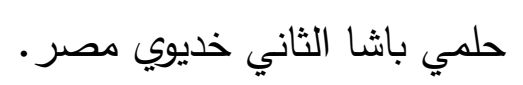

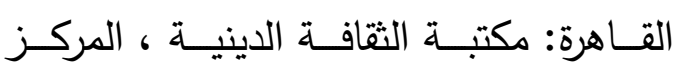

$$
\text { الإسلامي للطباعة. ب.ت. }
$$$$
\text { ^) السنجاري: علي بن تاج الاين. }
$$

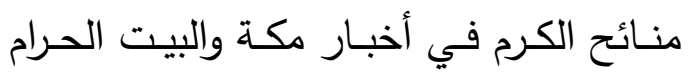

$$
\text { وولاة الحرم، جـ. }
$$

دراسة وتحقيق: ماجدة فيصل زكريا.

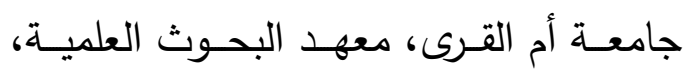

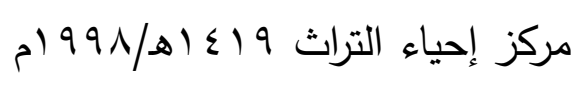

9) البكري: فيصل حسن.

$$
\text { جدة تاريخ وحضارة. }
$$

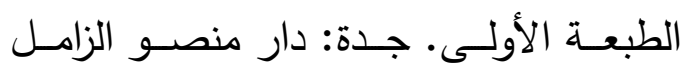

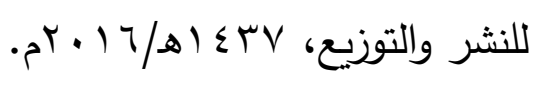

• (1) الثقفي: عبد الله زاهر .
وثائق منشورة:

- حجاز ولايتي سالنامه سي لعام بـ بـ أهـ

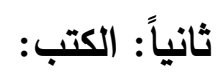

(1) اسماعيل: صابرة مؤمن.

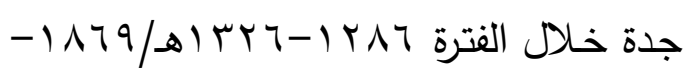

^ • 9 (م، دراســة تاريخيــة وحضــارية فـي

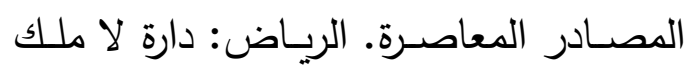

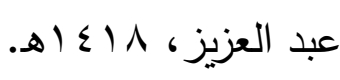

r) الأنصاري: عبد القدوس:

موسوعة تاريخ جدة.

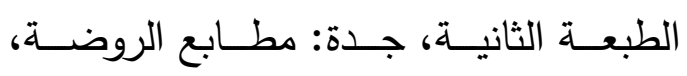

$$
\text { 1 إهـ/919 ام، الجزء الأول. }
$$

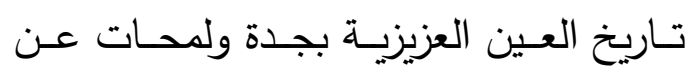
مصادر المياه في المملكة العربية السعودية. طبع على نفقـة إدارة العين العزيزيـة بجدة.

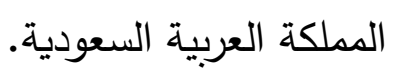

$$
\text { r) (اوكسنولد: وليم. }
$$

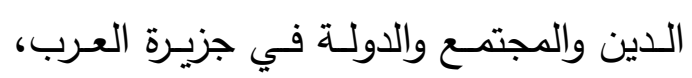

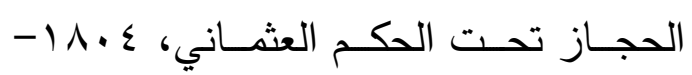
A • 9 ام، ترجمة: عبد الرحمن سعد العرابي.

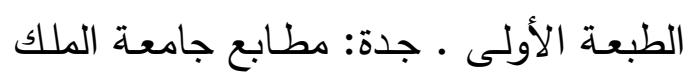

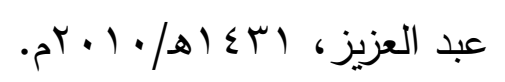

ع) باشا: إبراهيم رفعت.

مـرآة الحرمين أو الـرحلات الحجازيــة والحـج

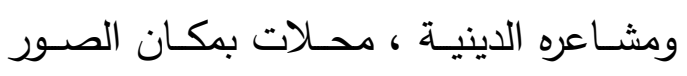


نادي مكة الثقافي، ع • ع اهـ/؟19 ام.

$$
\text { رقام: محمد درويش. }
$$

جدة داخل السور • كتبه وأعده للنشر : عبد الله فراج الشريف.

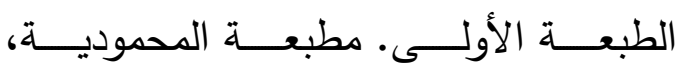

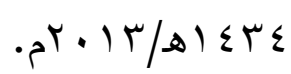
السليمان: سلوى عبد القادر.

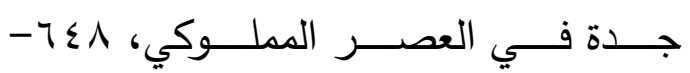
. $0101 \mathrm{~V}-1$ YO./9Tr جـدة : مطبوعـات النـادي الأدبـي الثقــافي. ب.ت. ) (1) صابان: سهيل. مـداخل لـبعض أعـلام الجزيـرة العربيـة في الأرشيف العثماني، الطبعـة الثانيـة، الكويتي: جداول للنشر والترجمة والتوزيع، با ـ ـ بم. طرابلسي: محمد يوسف. جدة حكاية مدينة.

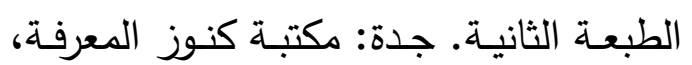
. $1 \leqslant Y q$

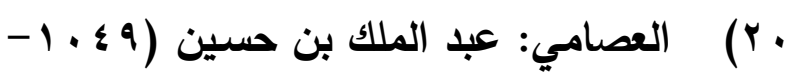
( 1) - (1)

سـمط النجـوم العــوالي فـي أنبــاء الأوائـلـ والتوالي، جء. القاهرة : المطبعة السلفية ومكتبتها. ب.ت.
العمـارة بمدينـة جـة في العصـر العثمـاني،

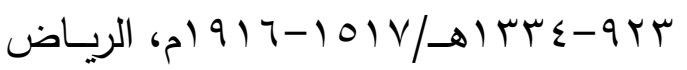

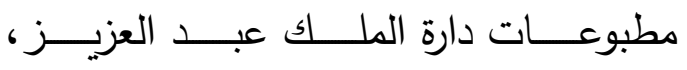
. جارسلي: اسماعيل حقي أوزون امراء مكة المكرمة في العهد العثماني. ترجمـة: خليـل علـي مـراد. تقـديم وتحقيـق: عارف عبد الغني. دمشـق : دار العـرب ودار نــوران للدراسـات والنشر والترجمة، ب • Y (م. الحضراوي: أحمد بن محمد. الجواهر المعدة في فضائل جدة. تحقيق: علي عمر الطبعة الثانية، القاهرة: مكتبة الثقافة الدينية. . دحلان: أحمد زيني. (1) تاريخ أشراف الحجاز • تحقيق وتحليل : محمد أمين توفيق.

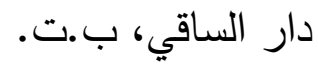
دياب: محمد صادق. جدة، التاريخ والحياة الاجتماعية الطبعة الثانية، ب.ت. م) السباعي: أحمد. تاريخ مكة، جا ا . الطبعـة السادسـة. مكـة المكرمسة: مطبوعـات 


$$
.5191 \cdot / 814 \cdot V
$$

ترجمـة: مصـطفى محمــــــــــان، مراجعـة: محمد بن سويلم الثامان. الريـاض: مطبوعات دارة الملك عبد العزيز ،

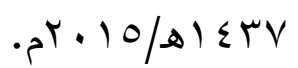

الكردي: محمد طاهر.

التاريخ القويم لمكة وبيت الله الكريم. المجلد

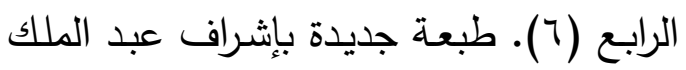
بن عبد الله بن دهيش. الطبعة الثالثة. مكة

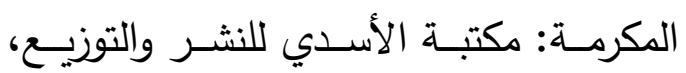
• المحامي: محمد فربد بك. تاريخ الدولة العلية العثمانية. تحقيـق : احسـان حقـي. الطبعـة الثانيـة،

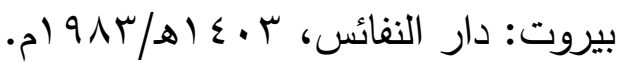
المعبدي: مبارك محمد.

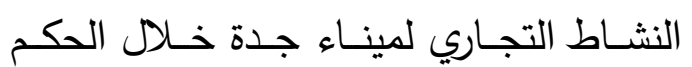

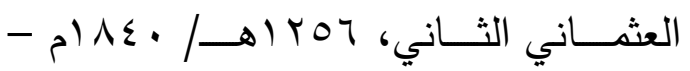
- lo جدة : النادي الأدبي الثقافي. ب.ت. مغربي: محمد علي. أعلام الحجاز في القرن الرابع عشر للهجرة

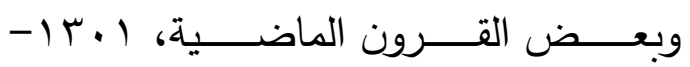

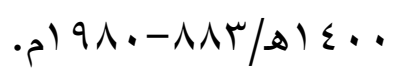

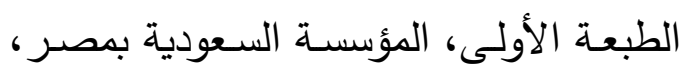

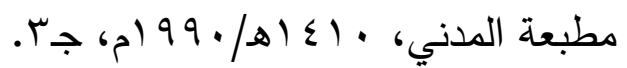

الغازي: عبد الله بن محمد.

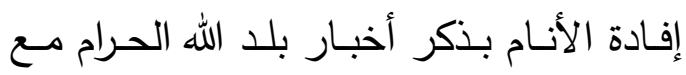
تعليقه المسدى باتمام الكلام. جء، جـr.

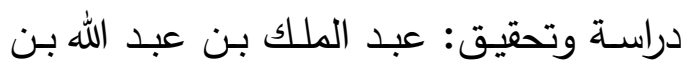

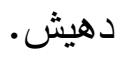

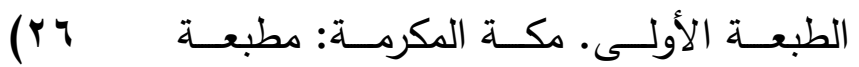

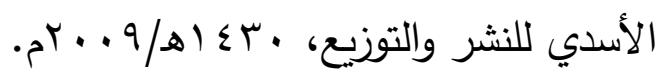
الغامسـي : محمـــ جمعـان (rY

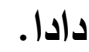

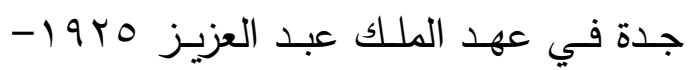
.p 904

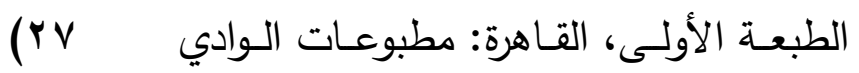

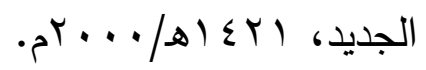
غباشي: عادل محمد نور. (rr

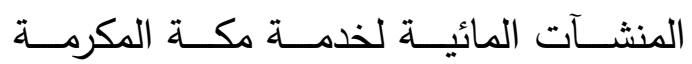

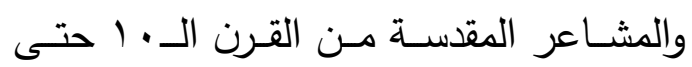

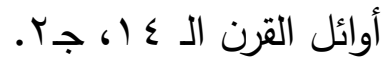

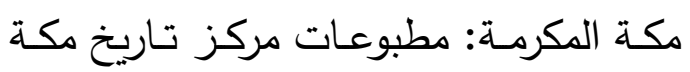

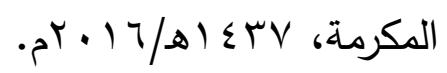
فهيم: محمد علي:

ملامـح النشـاط الاجتمـاعي في مكة المكرمـة

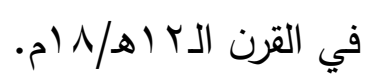

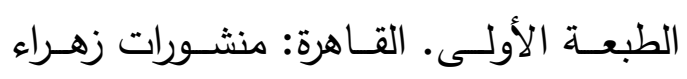

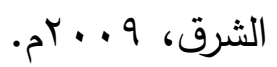
القيصري: محمد شاكر. (ro

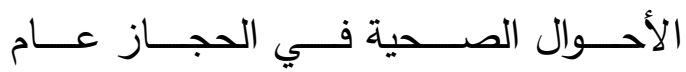


.01911

الطبعـــة الأولـى ــــــركة الـــوراق للنشــر

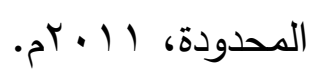

$$
\begin{aligned}
& \text { ثالثثاً: الاوروبات: } \\
& \text { (1)دعاع: سحر بنت علي }
\end{aligned}
$$

عثـان بـن نـوري باشـا وإصـلاحاته في مكـة

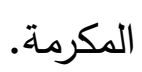

مجلـة كليـة الآداب. جامعـة الزقازيق ، العدد

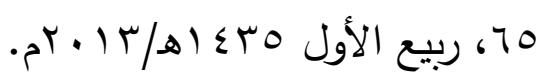

$$
\begin{aligned}
& \text { r) غباشي: عادل محمد نور. }
\end{aligned}
$$

إيصال مياه العيون إلى مدينة جدة.

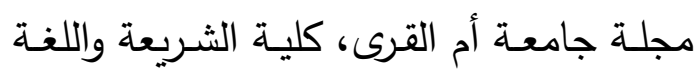

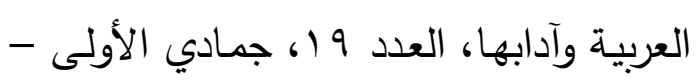

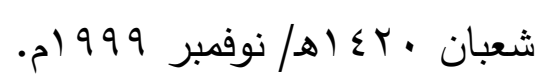

r) صحيفة الثرق الأوسط.

قصسة تحليـة الميـاه في السـعودية مسن زمـن

الكنداسة إلى تجربة دولية رائدة خلال قرن -

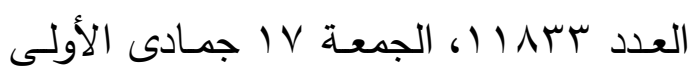

r

رلبعاً : المطبوعات الحكومية:

لجنة العلاقات العامة بإدارة العين العزيزية: لمحات

$$
\text { عن العين العزيزية بجدة. }
$$

• منسي: عبد الله سراج.

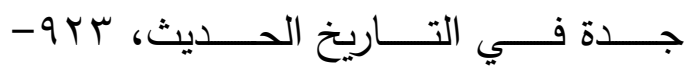

$$
\begin{aligned}
& \text {. م) } 947-101 \mathrm{~V} / 01 \mathrm{~s} \leqslant \varepsilon \\
& \text { هورخوزيه: سنوك. }
\end{aligned}
$$

صفحات من تاريخ مكة المكرمسة، جـ (، نقله إلى العربية: علي عودة الثيوخ، أعد صياغته وعلق عليه : محمد محمود السرياني ومعراج

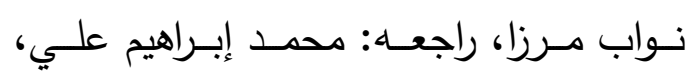
الريـاض: دارة الملك عبـد العزيـز ، صــدر بمناسبة مرور مائة عام على تأسيس المملكة العربية السعودية، 9 1ـ (هـ/999 (م.

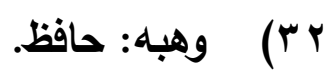
جزيرة العرب في القرن لاعشرين. طبعـة خاصــة. بيـروت: شـركة فؤاد البعينـو

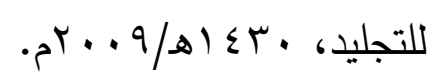
r ) يلدز : جولدن صاري.

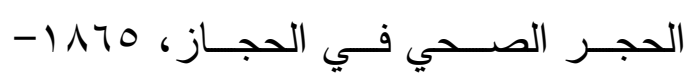
•p) $91 \leqslant$ ترجمـهـ عـن التركيـة وقـدم لـه: عبـد الـرزاق بركات. مراجعة: سعد الشامات. الطبعة الأولى. مركز الملك فيصل للبحوث

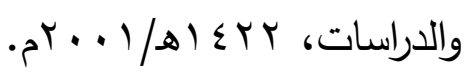
يوسف: عماد عبد العزيز. 


\title{
Jeddah People's Efforts to provide Freshwater for their City 1261-1334 H. / 1845-1916 G.
}

\author{
Dr. Dalal Bint Mohammed Bin Suleiman Al-Saied \\ Associate Professor of Modern \& Contemporary History \\ History \& Monuments Dept. \\ Faculty of Social Sciences \\ University of Jeddah
}

\begin{abstract}
Jeddah People's Efforts to provide Freshwater for their City during period from 1261 to $1334 \mathrm{H}$. / 1845 to $1916 \mathrm{G}$.

The importance of the subject is cultural \& civilized study which spot on vital and main resource for contusing of life "Water", also this is a new study which shows Jeddah People's Efforts to provide Freshwater for their City, the study based on documents that published for $1^{\text {st }}$ time and obtained from Ottoman Archives in Istanbul \& King Abdul Aziz Collection Library, in addition to most of books as resources $\&$ references, also attached some maps \& images as appendixes.

This study aims to show important side of Jeddah City history and showing the old people efforts to serve their city, and how they were cooperated with more efforts to support the government of country, also this study aims to shows how Jeddah's people suffered in the past and carried many difficulties for providing freshwater which need to spend efforts to keep \& save it currently by rationing water use, the study aims too for encouraging the researchers and historians to make studies which showing anonymous and mysterious sides of Jeddah city history.

The study included historical gate about Jeddah water resources in the past, then five subjects due to historical periods and projects that already implemented, this projects included The Trader "Farag Yousr" initiative to re-extend freshwater panels from Al-Rughamah in east of Jeddah, efforts of the Trader "Selim Sultan" for Seawater desalination, then create a spring of water Ain Al-Hamidiah "Al-Waziriah" which supported by Jeddah people, also shows the seawater distillation device "Al-Qindasah". Finally, shows how the city people created National Company for searching on water resources at Jeddah City, this study concluded with most important results.
\end{abstract}

- Allah Blessing, 